\title{
Morphological data, extant Myriapoda, and the myriapod stem-group
}

\author{
Gregory D. Edgecombe \\ Australian Museum, 6 College Street, Sydney, NSW 2010, Australia, e-mail: greged@austmus.gov.au
}

Keywords: Myriapoda, phylogeny, stem-group, fossils

\begin{abstract}
The status of Myriapoda (whether mono-, para- or polyphyletic) and position of myriapods in the Arthropoda are controversial, an impediment to evaluating fossils that may be members of the myriapod stem-group. Parsimony analysis of 319 characters for extant arthropods provides a basis for defending myriapod monophyly and identifying those morphological characters that are necessary to assign a fossil taxon to the Myriapoda. The alliance of hexapods and crustaceans need not relegate myriapods to the arthropod stem-group; the Mandibulata hypothesis accommodates Myriapoda and Tetraconata as sister taxa. No known pre-Silurian fossils have characters that convincingly place them in the Myriapoda or the myriapod stem-group. Because the strongest apomorphies of Myriapoda are details of the mandible and tentorial endoskeleton, exceptional fossil preservation seems necessary to recognise a stem-group myriapod.
\end{abstract}

\section{Contents}

Introduction

Arthropod phylogeny: the Recent tree 208

Taxonomic and character sampling 209

$\begin{array}{ll}\text { Cladistic methods } & 210\end{array}$

Results $\quad 210$

Reconstructing the myriapod ground pattern $\quad 213$

Autapomorphies of Mandibulata "' 213

$\begin{array}{ll}\text { Mandible } & 213\end{array}$

First maxilla $\quad 216$

Ommatidium with crystalline cone [Mandibulata] and multilayered rhabdom [Myriapoda] $\quad 217$

Other characters $\quad 218$

Autapomorphies of Myriapoda $\quad 218$

Tentorial bars and tentorial mobility $\quad 218$

Separated, independently musculated gnathal lobe $\quad 220$

\begin{tabular}{l|l} 
Other characters & 221
\end{tabular}

Mandibular comb lamellae 221

"Tracheate" characters in Myriapoda 221
Tagmosis: long-bodied fossils 222

Fossil candidates for the stem-group? 222

Conclusions $\quad 225$

Acknowledgments 225

References _. 225

Appendix 1. Characters used in phylogenetic analysis 233

Appendix 2. Characters optimised on cladogram in

Fig. 2

"Perhaps the most perplexing of the arthropod taxa are the myriapods" (Budd, 1998: 136).

\section{Introduction}

Myriapods confound palaeontologists. For all that Cambrian Lagerstätten like the Burgess Shale and Chengjiang have contributed to knowledge of basal arthropod inter-relationships, they are notably silent on the matter of myriapod origins and affinities. Few comparisons have been made between Cambrian marine organisms and members of the myriapod crown-group, i.e., the Chilopoda (centipedes) and Progoneata (symphylans, pauropods and millipedes). The dearth of well-founded comparisons is a reflection of real patterns in the fossil record (a lack of appropriately-aged soil and litter faunas) and the cryptic, terrestrial habits of crown-group myriapods, but it is also influenced by imprecise or flawed concepts of myriapod morphology and relationships. Identifying fossils that may be members of the myriapod stem-group requires a wellfounded hypothesis of myriapod phylogeny in the broader context of Arthropoda, based on precisely defined apomorphic characters that can potentially 
be examined in fossil material. As Budd et al. (2001: 38) noted when evaluating the "myriapod-like" Cambrian fossil Xanthomyria, "The ground-plan features for many groups [of arthropods] remain uncertain". That uncertainty impedes understanding the significance or possible contributions of fossils.

The palaeontological context of Myriapoda has been reconsidered based on developments in arthropod phylogeny that have come from exclusively neontological data, such as gene order, neurogenesis, and molecular sequences. Budd (1999: 286), for example, considered the possibility of a crustaceanhexapod alliance to invite a radical repositioning of the Myriapoda: "It is hard to see how the myriapods may be considered to be the sister group to any of the arthropod stem-group taxa discussed here...; if the Tracheata [=Myriapoda + Hexapoda] are to be abandoned, the possibility of myriapods representing an independent line of arthropodisation (from a lobopodous ancestor) remains open...". Likewise, "Regarding insects as derived crustaceans certainly makes fitting in the myriapods difficult... But if they do not fit in here, then there is no other obvious place for them to be tied into arthropod phylogeny" (Budd, 2001: 71).

The enigmatisation of myriapods has not been exclusively palaeontological. Rejection of a myriapod-hexapod alliance (the Tracheata or Atelocerata) after decades of almost universal acceptance stemmed first from analyses of molecular sequence data, such as studies based on small subunit rRNA (Friedrich and Tautz, 1995, 2001; Giribet et al., 1996). These analyses offered an alternative resolution of myriapods as sister group of Chelicerata, though this result was rejected, or at best rendered ambiguous, for the same genes with denser taxonomic sampling (Giribet and Ribera, 1998, 2000). A division of Euarthropoda into (Chelicerata + Myriapoda) and (Crustacea + Hexapoda) has, however, been endorsed in some other molecular analyses, including those based on Hox gene sequences (Cook et al., 2001), sequences for much of the mitochondrial genome (Hwang et al., 2001; Delsuc et al., 2003), and hemocyanin sequences (Kusche and Burmester, 2001; Kusche et al., 2002). Independent support for the exclusion of Myriapoda from a crustacean-hexapod clade has come from nuclear coding genes (Regier and Shultz, 1997, 2001a, b; Shultz and Regier, 2001) as well as from several kinds of non-sequence data. The latter includes brain ultrastructure (Strausfeld, 1998; Loesel et al., 2002), neurogenesis (Duman-Scheel and Patel, 1999; Simpson, 2001), eye ultrastructure (Melzer et al., 1997), and mitochondrial gene order (Boore et al., 1998). These studies [reviewed by Dohle (2001) and Richter (2002a)] have contributed to a perception that myriapods are more "basal" than crustaceans and hexapods.

In short, Myriapoda is variably seen, even in the latest literature, as either monophyletic (Edgecombe and Giribet, 2002), paraphyletic (Kraus, 2001) or polyphyletic (Loesel et al., 2002). Myriapods are variably allied to either hexapods, chelicerates, or a crustacean-hexapod clade, or are left unassigned in the euarthropod stem-group. The present review aims to establish constraints on the systematic position of myriapods by synthesising character evidence available for their crown-group in the context of other extant Arthropoda. Data come from a range of non-sequence sources, including external morphology, internal anatomy, ultrastructure, embryology, gene expression, and gene order. Cladistic analysis of this evidence permits the ground pattern of the myriapod crown-group to be clarified. This in turn allows fossils, including potential stemgroup Myriapoda, to be evaluated more precisely.

\section{Arthropod phylogeny: the Recent tree}

It hardly need be said that extant taxa have some advantages over fossils. Some classes of character data, such as mitochondrial gene order and sperm ultrastructure, are confined to extant taxa, as is true for most other genetic and ultrastructural information and many soft anatomical characters. The escalation of missing data for fossils is not confined to molecular data; a sobering proportion of the nonsequence characters analysed in this study (see Appendix) are unknown for all fossils, e.g., whole blocks of characters for embryology, brain and eye structure, and muscles. For extant taxa, conjectures of primary homology can refer to gene expression patterns (see the example of Distal-less and dachshund expression in the mandible below), embryo- 
logical development, and details of ultrastructure that will be unknown for fossils. These details permit a rigour in formulating hypotheses of homology that may not be possible with fossils, and larger suites of character data (including more kinds of character data) are available. I shall not, however, endorse the conclusion drawn by Patterson and Rosen (1977) that these epistemological matters mean that fossils are subordinate to extant taxa in phylogenetic analysis. It has been amply demonstrated that a Recent-only tree may be overturned on the basis of including extinct taxa in the sample, a phenomenon that has been defended both theoretically and empirically (Gauthier et al., 1988; O'Leary, 1999).

The present analysis is confined to extant taxa because the terminal taxa are selected to include groups for which multiple-gene molecular samples are available, permitting combined-data approaches to arthropod phylogeny (Giribet et al., 2001). In a palaeontological context, it serves as the "Recent tree", a hypothesis that can be tested, and potentially overturned, by the inclusion of fossil taxa. Despite all missing codings for molecular (and many non-molecular) characters in fossils, extinct terminals could be included in the taxonomic sample (see Schram and Hof, 1998, and Giribet et al., 2002, for analyses of crustacean and arachnid relationships, respectively, that score fossil taxa for their morphological characters).

\section{Taxonomic and character sampling}

The present study expands upon the morphological character set of Giribet et al. (2001), which was modified from a synthesis by Edgecombe et al. (2000). The Edgecombe et al. (2000) dataset included 211 characters for Arthropoda s.l. (= Onychophora + Tardigrada + Euarthropoda or Arthropoda s. str.). Characters in that work that pertained to Annelida or which are invariant in the in-group for this study (autapomorphies of Arthropoda s.l.) are now excluded. The in-group is Euarthropoda, with peripatid and peripatopsid onychophorans and tardigrades used as out-groups. Participants in the Ecdysozoa versus Articulata debate [see SchmidtRhaesa et al. (1998) and Scholtz (2002), respec- tively, for summaries from opposing perspectives) have agreed on the monophyly of Onychophora + Tardigrada + Euarthropoda.

The taxonomic sample is designed to span the major groups within the extant Arthropoda. Taxonomic sampling is based on terminal taxa for which at least four of eight widely-sampled nuclear ribosomal, nuclear protein-coding, and mitochondrial genes are available (see Giribet et al., 2001). The terminal taxa used here are as in Giribet et al. (2001) with the addition of the myriapods Cryptops (Chilopoda: Scolopendromorpha) and Spirostreptoidea (Diplopoda: Spirostreptida) for which most of the genes used in the molecular character set are now available. In many cases, marker diversity is maximised by combining sequence data from different species to code for a supraspecific terminal taxon, the assumptions of monophyly of these supraspecific groupings, e.g., Scütigeridae, Polyxenidae, Stomatopoda, being relatively unproblematic in the context of the deep branchings in arthropod phylogeny.

The data include a range of non-sequence evidence, including characters describing gene expression patterns and mitochondrial gene order, together with more traditional "morphological" characters (external morphology, internal anatomy, ultrastructure, embryology, and development). I have not segregated molecular versus non-molecular data, since the homology concepts used in formulating these characters are similar, all are amenable to parsimony analysis, and none involve the issues specific to sequence data, e.g., base frequencies, treatment of gaps, transversion:transition costs.

Earlier versions of the dataset (Edgecombe et al., 2000; Giribet et al., 2001) coded the traditional hypothesis of segmental correspondence between chelicerae and second antennae, which implied a loss of deutocerebral appendages in Chelicerata (Bullock and Horridge, 1965; Weygoldt, 1985). The present version instead codes for segmental homology between the cheliceral and first antennal segments, based on Hox gene expression domains (Damen et al., 1998; Telford and Thomas, 1998; Scholtz, 2001; see Hughes and Kaufman, 2002a, fig. 10) and patterns in development of the nervous system in Limulus (Mittmann and Scholtz, 2003). The alignment of segments in the head of euarthropods and onychophorans follows a model 
for Onychophora outlined by Eriksson and Budd (2000) and Eriksson et al. (2003).

\section{Cladistic methods}

The dataset includes 319 characters (Appendix 1, Table 1). Most multistate characters are coded as unordered. Characters 3, 27, 76, 134, 151, 164 and 211 present information that justifies coding for a transformation series, and are scored as ordered. Two characters ( 8 and 128) involving ontogeny are scored as variable ("either 1 or 2 but not 0 ").

Minimal length cladograms were computed with PAUP* version $4 \mathrm{~b} 10$ (Swofford, 2002). A heuristic tree space search was implemented with the commands: hsearch addseq $=$ random nchuck $=10$ chuckscore $=1$ nreps $=5000$ randomize $=$ trees; hsearch start $=$ current nchuck $=0$ chuckscore $=0$. As discussed above, trees are rooted between Euarthropoda and the onychophoran and tardigrade out-groups. Group support was evaluated by parsimony jackknifing (Farris et al., 1996), using PAUP*, with a heuristic search using 1000 replicates and $33 \%$ character deletion, saving one tree per replicate. Bremer support (Bremer, 1994) of up to 5 extra steps was computed using a heuristic search with NONA version 2.0 (Goloboff, 1998). To select a cladogram for showing character optimisations, successive approximations weighting (Farris, 1969) was applied with PAUP*, using the maximum fit of the rescaled consistency index (RCI).

\section{Results}

With the analytical procedures outlined above, parsimony analysis finds 648 shortest cladograms of 619 steps (Consistency Index $=0.65$; Retention Index $=0.87$; Rescaled Consistency Index $=0.56$ ). The strict consensus of these is shown in Fig. 1, indicating jackknife frequencies and Bremer support. Successive approximations weighting selects 54 of the minimal length cladograms based on equal weights. Ambiguity in the cladograms based on the reweighted characters is confined to the internal relationships of the Pantopoda, Opiliones, Juliformia within the Diplopoda, and Phyllopoda within the Branchiopoda, such that character optimisations at the basal nodes of Mandibulata and Myriapoda are unaffected. Character optimisations are shown on a cladogram selected by both equal weights and successive weights (Fig. 2, Appendix 2).

The higher-level clades are as in the most congruent combined (morphological + molecular) cladogram of Giribet et al. (2001), with Euarthropoda resolved as (Pantopoda (Chelicerata (Myriapoda (Crustacea, Hexapoda)))). Myriapoda is monophyletic but not strongly supported, with a jackknife frequency of $63 \%$ and a Bremer support of 1 . It is composed of the sister taxa Chilopoda and Progoneata (see Fig. 3 for taxonomic groupings in the Myriapoda). In some suboptimal cladograms (one step longer than the shortest) myriapod monophyly is contradicted in favour of a sister group relationship between the Progoneata and the Hexapoda, which together constitute the Labiophora (Kraus and Kraus, 1994).

The internal phylogeny of the Chilopoda identifies the Notostigmophora (order Scutigeromorpha) as the sister group of the four orders that comprise the Pleurostigmophora. This scheme of relationships is widely endorsed by morphologists (Shinohara, 1970; Dohle, 1985; Shear and Bonamo, 1988; Borucki, 1996; Prunescu, 1996; Edgecombe et al., 1999), and is congruent with the analysis of nuclear rRNA (Edgecombe et al., 1999) and the combined analysis with multiple molecular markers (Giribet et al., 2001). The Pleurostigmophora hypothesis contradicts the phylogeny and classification outlined by Ax (1999), in which the Geophilomorpha was resolved as sister to all other Chilopoda. Relationships of classes in the Progoneata are as argued by Dohle $(1980,1998)$ and Kraus and Kraus (1994), with the Symphyla as the sister group of the Dignatha (=Pauropoda + Diplopoda). In the Diplopoda, Penicillata (=Polyxenida) is the sister group of Chilognatha, and in the latter, Pentazonia

Fig. 1. Strict consensus of 648 minimal length cladograms of arthropod relationships based on data in Table 1. Numbers above nodes are Bremer support; numbers below nodes are parsimony jackknife frequencies. 


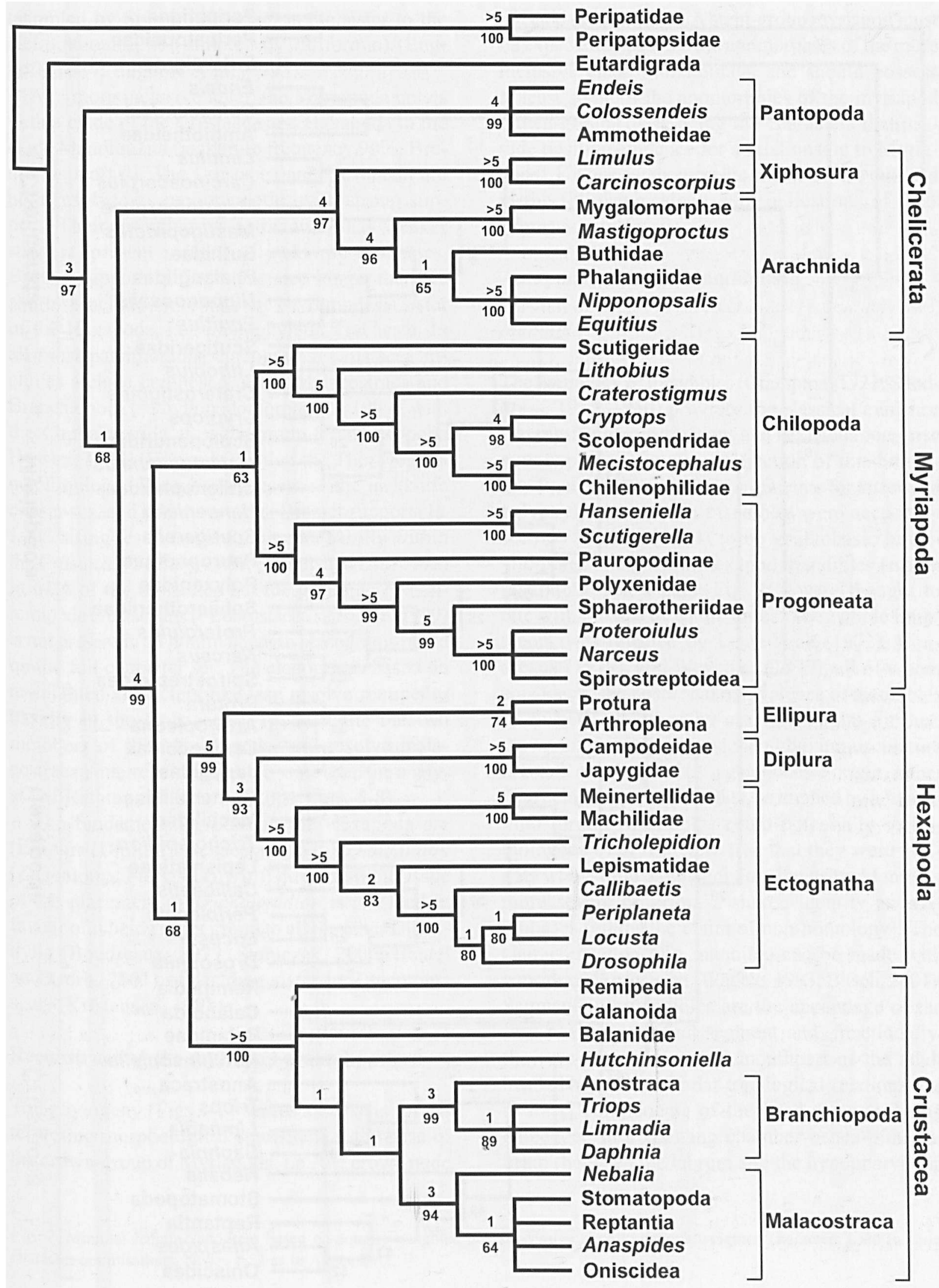




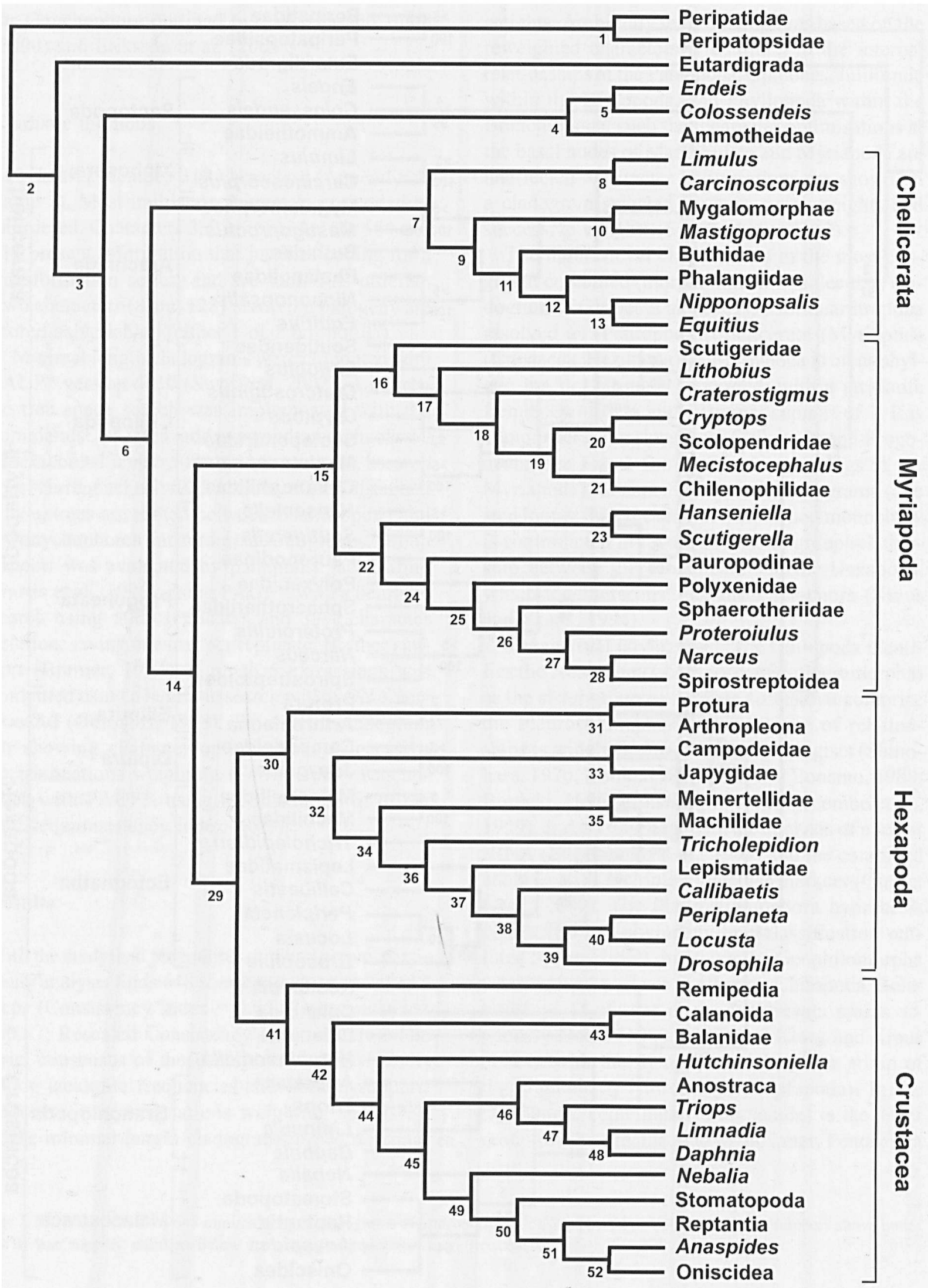


(sampled by Sphaerotheriidae) is the sister to the Helminthomorpha (sampled by Juliformia) (Enghoff, 1984; Enghoff et al., 1993).

At a more inclusive level, the Myriapoda unites with a clade of the Crustacea and Hexapoda in the clade Mandibulata (jackknife frequency $99 \%$, Bremer support 4). The Crustacea and Hexapoda are both resolved as monophyletic, with strong support. Their grouping as Tetraconata has weaker support (present in $68 \%$ of jackknife replicates, Bremer support 1). Trees one step longer than the shortest include some with the Myriapoda as sister of the Hexapoda, i.e., monophyletic Tracheata. In all most parsimonious cladograms, Crustacea includes a clade composed of the Malacostraca and Branchiopoda (=Phyllopodomorpha Ax, 1999), with the Cephalocarida as sister group (=Thoracopoda Hessler, 1992). However, neither the Thoracopoda nor Phyllopodomorpha is present in the jackknife consensus, and both have weak Bremer support (1). Jackknifing resolves the Remipedia basally within the Crustacea (Schram, 1986; Schram and Hof, 1998) in $61 \%$ of the replicates but the grouping of nonremipede crustaceans (=Eucrustacea sensu Ax, 1999) is not present in all minimal length cladograms based on the full character set. The cladograms based on reweighted characters likewise resolve remipedes basally in the Crustacea (Fig. 2), unite the two members of the Maxillopoda, and resolve malacostracan interrelationships the same as in the analysis of Richter and Scholtz (2001: figs. 5-8).

The fundamental groups in the Hexapoda are (Ellipura (Diplura (Archaeognatha (Tricholepidion (Zygentoma, Pterygota)))))). The contentious issue of the placement of Tricholepidion is resolved in favour of it being sister group to all the other Dicondylia (Boudreaux, 1979; Staniczek, 2000; Beutel and Gorb, 2001) rather than sister to Zygentoma s.str. (Kristensen, 1998).

\section{Reconstructing the myriapod, ground pattern}

The phylogeny (Figs 1-3) serves as a basis for interpreting morphological characters at the base of the crown-group of Myriapoda, i.e., the crown node of Budd (2001: fig. 1). A stem-group myriapod must be expected to possess the apomorphies of the more inclusive clade Mandibulata, and should possess at least some of the apomorphies of the myriapod crown-group (these being the characters that provide positive evidence for a relationship to Myriapoda). Unique autapomorphic characters are outlined in the following, along with indications of their expression in fossils.

\section{Autapomorphies of Mandibulata}

\section{Mandible}

The homology of mandibles (Crampton, 1921; Snodgrass, 1938, 1950) provides the classical evidence that myriapods, crustaceans and hexapods comprise a monophyletic group. A rejection of this homology figured prominently in arguments for arthropod polyphyly. Crustacean mandibles were accurately seen by Manton ..(1964) to be gnathobasic in origin, but myriapod and hexapod mandibles (which invariably lack a palp: Fig. $4 \mathrm{C}$ ) were thought to bite with the tips of whole limbs. The 'whole limb' theory was rejected by Lauterbach (1972), Boudreaux (1979), and Weygoldt (1979), all of whom considered the positional equivalence of mandibles to be best explained by a single origin. Further, they argued that myriapod mandibular musculature is coxal, as is implied by a gnathobasic origin, rather than being that of a telopodite, as implied by a 'whole limb' origin [mandibles could potentially be homologous even if it were true that they were variably whole limb or gnathobasic, but using Manton's more severe criterion, a shared identity as gnathobases refutes the claim of non-homology]. The characterisation of a mandible can be made with considerable precision (Wägele, 1993; Bitsch, 2001). Segmentally, mandibles are the appendage of the first post-tritocerebral segment and, functionally, they are the anteriormost mouthpart of the adult head. They share similar topological relationships to other components of the head capsule, being embedded in a chewing chamber beneath the labrum (between the labrum and the hypopharynx in

$\leftarrow$

Fig. 2. Minimal length cladogram based on equally weighted and successive approximations weighted characters used to show character optimisations. Nodes 1-52 as in Appendix 2.: 


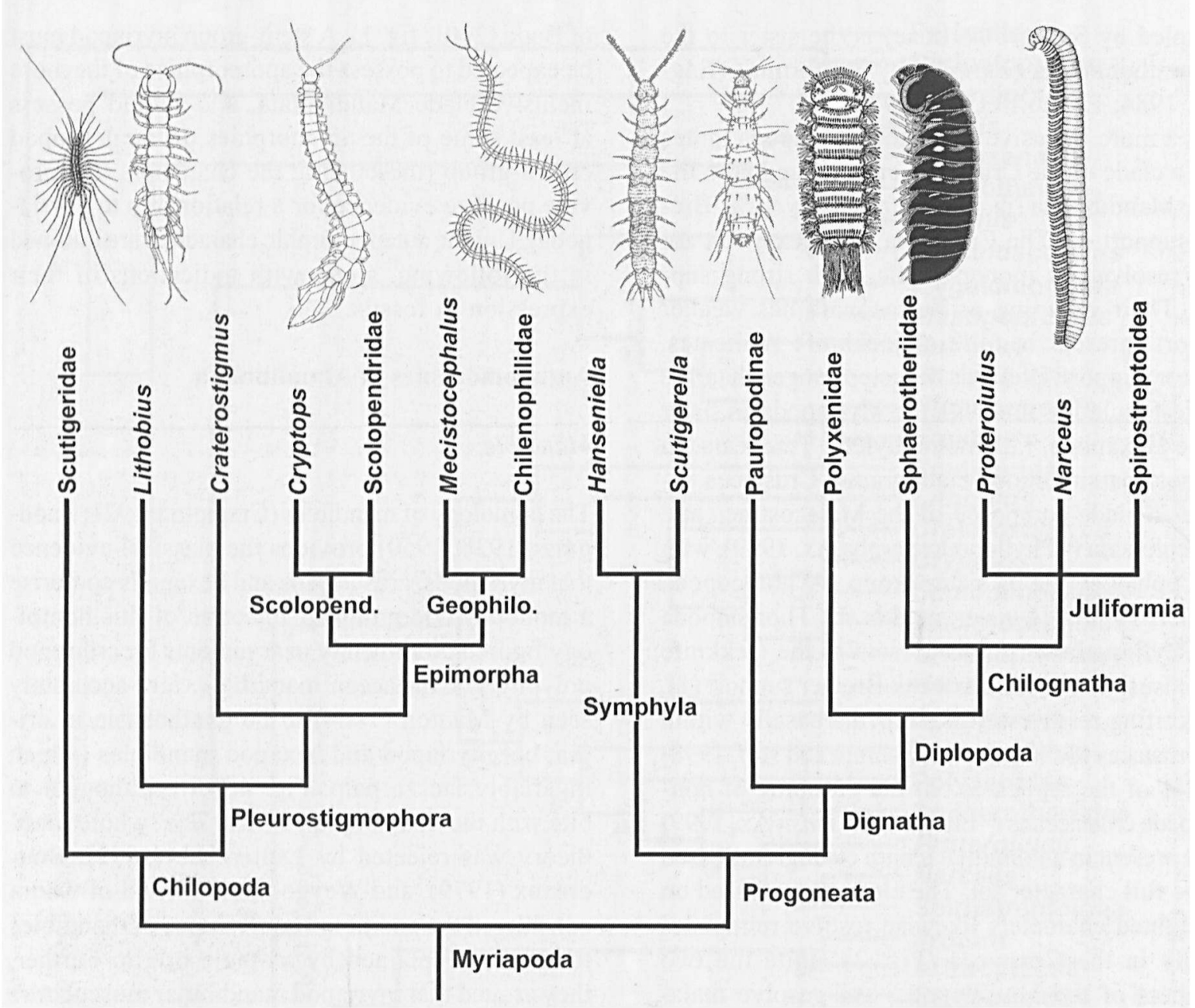

Fig. 3. Cladogram for extant Myriapoda using taxonomic sample in Figs. 1 and 2, showing higher-level systematic groupings and exemplar organisms. Ordinal names (Scolopendromorpha and Geophilomorpha) abbreviated within Epimorpha. Drawings from Eason (1964), Eisenbeis and Wichard (1985), Harvey and Yen (1989), Hennig (1972) and Snodgrass (1952).

myriapods: Fig. 4A), and have a coxal endite used for food manipulation.

Gene expression data are consistent with the homology of the mandibles throughout the Mandibulata. Though these data are not amenable to observations on fossils, they are important because they contribute to the general question of homology (Scholtz, 2001; Richter, 2002a). In the diplopod Glomeris, the Homeobox gene Distal-less has only a temporary expression in a lateral position, which, by comparison to Crustacea, is interpreted as the vestigial anlage of a palp (Scholtz et al., 1998). In adult myriapods, distal parts of the mandible are therefore lacking, which invalidates Manton's concept of a whole limb mandible, i.e., biting with the tip of a whole limb. Distal-less expression is entirely absent in hexapods (Panganiban et al., 1995; Niwa et al., 1997; Popadić et al., 1996, 1998; Scholtz et al., 1998). These data are consistent with myriapod and hexapod mandibles being gnathobasic like those of crustaceans. A coxal identity of the mandible is also suggested by dachshund expression in the beetle Tribolium (Prpic et al., 2001). Expression patterns are similar in all three gnathal appendages (mandible, maxilla and labium). This similarity suggests a serial homology between the entire mandible and the coxal parts of the maxilla and labium and the coxa of the legs.

Another important observation concerning the homology of mandibles is the absence of Distal- 

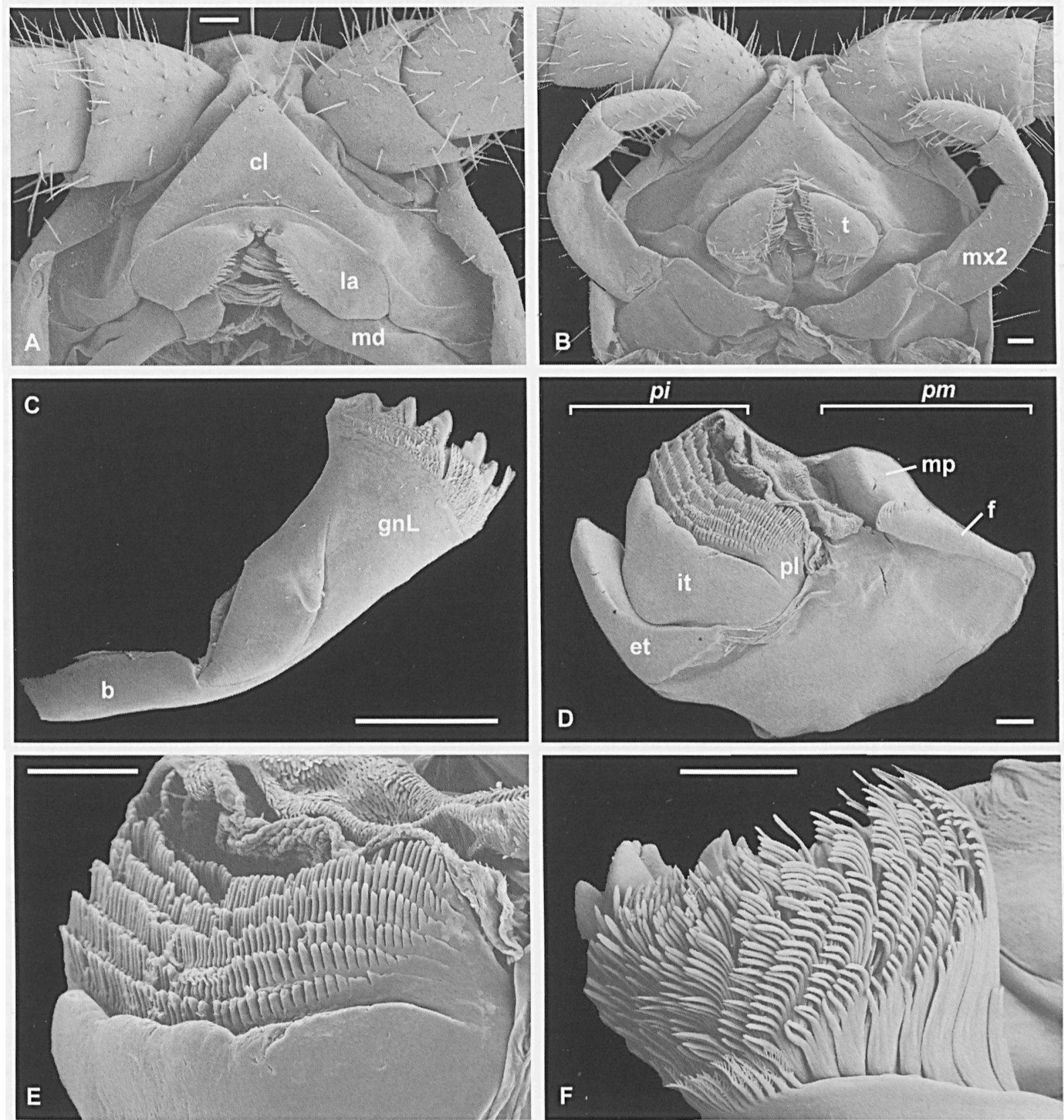

Fig. 4. Scanning electron micrographs of gnathal characters in extant Myriapoda. All scales $100 \mu \mathrm{m}$. A-C, Chilopoda, Lithobiomorpha; D-E, Diplopoda, Polydesmida; F, Chilopoda, Scutigeromorpha. A, Paralamyctes (Haasiella) subicolus. Ventral view of head, showing mandible (md) embedded beneath labrum (la) and clypeus (cl); B, Paralamyctes (Thingathinga) ?grayi. Ventral view of head, showing first maxillae bordering mouth. $\mathrm{t}$, telopodite of first maxilla. C, Paralamyctes (Haasiella) cammooensis. Mandible, showing division into gnathal lobe $(\mathrm{gnL})$ and base (b). D-E, Cladethosoma clarum. D, gnathal lobe of mandible, showing pars incisivus (pi) with external tooth (et), internal tooth (it) and pectinate lamellae (pl) and pars molaris (pm) with molar plate (mp) and anterior fringe (f); E, detail of pectinate lamellae. F, Scutigerina weberi. Distal part of gnathal edge, showing pectinate lamellae. 
less expression in the corpus mandibularis (Scholtz et al., 1998; Scholtz, 2001; Richter, 2002a). Distal-less expression is transitory if present at all, and is confined to an area that represents a palp anlage, whereas in the maxillula/first maxilla and in other limbs, Distal-less can be expressed in the inner lobes as well (Scholtz, 2001; Richter, 2002a). The mandible is thus differentiated from other, more posterior limbs with respect to this aspect of Distal-less expression.

The gnathal edge of the mandible in myriapods, crustaceans and hexapods shows further similarities that suggest correspondences in substructures (Edgecombe et al., 2003). In particular, the mandibular gnathal edge in taxa within each of these groups is differentiated into a distal incisor part, or pars incisivus, and a proximal molar part, or pars molaris (Fig. 4D). The pars incisivus is typically a blade-like process with a row of teeth (e.g., in Symphyla: Richter et al., 2002, figs. 39, 41, 43). The pars molaris typically has a flattened surface, displaying evidence for origination by fusion (or close contact) of spines that are arranged in rows (see Edgecombe et al., 2003, for examples from the Chilopoda, Symphyla, Ellipura, Insecta, Malacostraca and Branchiopoda). The pars molaris is fringed on one side by a row of spines with open gaps between the spines, and generally has a cluster of spines or bristles proximal to the molar plate or process. The broad homology of the pars molaris was suggested by Kraus (1998, his "Molar hook"), as a synapomophy for Myriapoda and Hexapoda, and subsequently extended to the pars molaris of Crustacea (Kraus, 2001).

In summary, a single origin of mandibles is indicated by topological relationships of the mandible within the head capsule, details of gene expression and musculature that indicate a coxal identity, and detailed substructures of the gnathal edge, including the pars molaris and its surface built up from spine rows. Fossils that are being evaluated as potential stem-group myriapods should possess mandibles of the same kind as other Mandibulata. The mandible in crown-group myriapods is strongly sclerotised, and this renders it especially prone to fossilisation. For example, the scolopendromorphs Mazoscolopendra richardsoni (Mundel, 1979: fig. 2) and Cratoraricus oberlii (Wilson, 2003: figs 3,
4) from the Carboniferous and Cretaceous, respectively, are known to have mandibles of the same size and topological relationships as the mandible of extant Scolopendromorpha. The Devonian chilopod Devonobius has the mandible in a comparable position under the labrum and paralabral sclerites as in extant Scolopendromorpha and Craterostigmus (Shear and Bonamo, 1988: figs. 14, 17 versus 49, 50 ). In any stem-group myriapod, the mandible is expected to be embedded in a chewing chamber between the labrum and the hypopharynx (character of the Mandibulata) (cf. Fig. 4A). Absence of the palp is a general character of the myriapod crown-group (Fig. 4C). The coding adopted for the mandibular palp (character 128) allows that its presence in larval stages is general for Crustacea, and it is likely that a palp is present in basal mandibulates.

\section{First maxilla}

All members of the mandibulate crown-group share a modification of the postmandibular appendage as a mouthpart, variably called a maxillula (Crustacea), maxilla (Hexapoda), first maxilla (Chilopoda), or incorporated into the gnathochilarium (Diplopoda). Detailed homology of substructures of the maxillae, however, is less developed than is the case for the mandible. Whether particular endites of the maxilla that are conserved across groups, such as the lobate maxillulary endites of crustaceans or the lacinia and galea of the Hexapoda, have broader homologies between groups is presently unknown. The serial comparison of gnathal appendages in embryos (Machida, 2000; Prpic et al. 2001) might shed light on this question.

Most evidence indicates that the first maxilla borders the mouth at the crown node of Myriapoda. The taxon Monomalata, which was conceived as including Chilopoda, Diplopoda and Pauropoda, was based on this relationship, "transformation of the first post-mandibular pair into a labium-like organ closing the pre-oral cavity from behind" (Sharov, 1966: 66). A debate over whether or not diplopods and pauropods express a second maxilla (Hilken and Kraus, 1994; Kraus and Kraus, 1994) or lack an appendage on the postmaxillary segment (Dohle, $1980,1998)$ impacts upon the question of which maxillary segment borders the mouth. The com- 
bined evidence from innervation, embryology, musculation, and gene expression favours the latter view (Scholtz et al., 1998). Dismissal of developmental data from the well-understood Glomeris as peculiarities of that taxon's distinctive gnathochilarium (Kraus, 2001) is weakened by helminthomorph diplopods, e.g., Oxidus (Popadić et al., 1998), showing the same embryological patterns as Glomeris.

Maxillary palps are uniformly present in Chilopoda, represented by a (generally) two-part telopodite (Fig. 4B). The absence of maxillary palps has been considered to be apomorphic for Progoneata (Kraus and Kraus, 1994). Claims that a palp is retained in penicillate diplopods (Shear, 1998) are disputed (Kraus and Brauckmann, 2003). Regardless of the interpretation in diplopods (or whether the lateral cone on the maxillary stipes in Symphyla is a vestigial palp), Chilopoda have a maxillary palp, as do Hexapoda and Crustacea, and its presence characterises the myriapod crown node.

Positive evidence for a fossil being a stem-group myriapod would therefore be provided by having a maxilla differentiated as a gnathal appendage rather than a locomotory limb. The maxilla would form the rear border of the pre-oral cavity (cf. Fig. 4B in Chilopoda), and should retain the presence of a palp or telopodite.

\section{Ommatidium with crystalline cone [Mandibulata] and multilayered rhabdom [Myriapoda]}

A crystalline cone composed of four cone (or Semper) cells is accepted as part of the ground pattern for Crustacea and Hexapoda (Paulus, 1979, 1989, 2000). Melzer et al. (1997) observed that processes from the cone cells pass between the retinula cells to the proximal basement membrane in the same, highly detailed manner in Crustacea (Triops, Lepidurus, Panulirus, Squilla, Argulus) and Insecta (Machilis, Drosophila), which Dohle (2001) cited as an important argument in favour of these taxa sharing a unique common ancestor. Interpretations of the myriapod stemmata (clusters of simple, singlelens ocelli) as a modified ommatidium (Paulus, 1986, 1989) have been more contentious. Most recently, Paulus (2000) suggested that remnants of cone cells may be represented by vitreous bodies between the lens and rhabdom in the pin-cushion millipede Poly xenus (Penicillata), and in this case the number of cells (four) is the same as in the typical "tetraconate" ommatidium. This agrees with the interpretation of Spies (1981) that the vitreous bodies of Polyxenus are relics of a crystalline cone. A crystalline cone has also been determined in Chilopoda, in the "pseudofaceted" eye of Scutigeromorpha (Hanström, 1934; Paulus, 1979, 2000), but with a larger number of cells than in Tetraconata. Other chilopods and diplopods lack a crystalline cone (Spies, 1981), but the data from Penicillata and Scutigeromorpha are significant because these lineages are sister groups of all other Diplopoda and Chilopoda, respectively (Fig. 3).

The possibility that a crystalline cone in the ommatidium is an apomorphy for the Mandibulata (Richter 2002a) is suggested by its shared presence in members of Chilopoda, Crustacea, Hexapoda, and possibly Diplopoda (Symphyla and Pauropoda are uniformly blind). Polarity is determined by outgroup comparison with Xiphosura, the only chelicerates that retain compound eyes. The faceted eye of Limulus has an extended cornea rather than a crystalline cone (Fahrenbach, 1999). A crystalline cone optimises on the cladogram in Fig. 2 as a mandibulate autapomorphy under accelerated transformation (ACCTRAN).

Another characteristic of myriapod lateral eyes, whether retaining evidence for being mandibulatetype ommatidia (Scutigeromorpha and, less confidently, Penicillata) or modified to form simple-eye stemmata (Chilognatha; Pleurostigmophora), is that the rhabdom is composed of multiple layers of retinular cells. In the case of Scutigeromorpha and Penicillata, the rhabdom has two layers of retinular cells, whereas many layers are present in Pleurostigmophora and Chilognatha (Paulus, 1979, 1986, 1989, 2000; Spies, 1981). Paulus (1986) viewed the layering of the rhabdom as a potential autapomorphy of Myriapoda because a similar construction occurs only in the larval eyes of some insects.

Fossils are unlikely to preserve ommatidial structure in adequate detail to determine the presence of a crystalline cone, the layering of the rhabdom, or other general conditions of myriapods, e.g., a variable and relatively large number of corneagenous cells compared to those of hexapods and crustaceans (Paulus, 2000). Concerning gross morphol- 
ogy of the lateral eyes, an arrangement into separated stemmata should be observable in fossil material, but distinguishing true ommatidia from "pseudofaceted" eyes can be difficult. For example, in Carboniferous diplopods, the eyes are composed of up to 1,000 units arranged in rows (Kraus, 1974), but whether these are faceted eyes is uncertain because the details needed to identify an ommatidium are not preserved (Spies, 1981). Stemmata appear to be diagnostic at less inclusive nodes than Myriapoda, possibly being apomorphic for Chilognatha within Diplopoda and Pleurostigmophora within Chilopoda (Kraus, 1998). Based on the ommatidia in the sister groups of these two clades, Penicillata and Scutigeromorpha, respectively, stem-group Myriapoda might be expected to possess a faceted (compound) eye with a crystalline cone.

\section{Other characters}

A few additional indicators for the monophyly of Mandibulata are not directly testable with fossil material. For example, a peritrophic membrane in the gut (character 188) and a restricted Antennapedia expression domain (character 317: Hughes and Kaufman, 2002b) are autapomorphies of Mandibulata under both accelerated and delayed transformation. Under accelerated transformation, additional autapomorphies of Mandibulata include fat body cells developed from walls of mesodermal somites (character 8: Anderson, 1973), a moulting gland (character 24: Wägele, 1993), three ganglia in the pre-oseophageal brain (character 50 ), midline neuropil 2 of Loesel et al. (2002) (character 54), and oocytes developing in the ovarian lumen (character 309: Makioka, 1988; Ikuta and Makioka, 1999).

\section{Autapomorphies of Myriapoda}

Reductive characters have figured in some arguments for monophyly of Myriapoda. For example, Ax (1999) cited the absence ("loss") of median eyes and a crystalline cone (but see above) as evidence for myriapod monophyly. Other shared absences noted in previous studies include the lack of a perforatorium in the sperm (Baccetti et al., 1979; Jamieson, 1987) and absence of scolopidial mecha- noreceptors (Paulus, 2000). The validity of a monolayered acrosome as a myriapod autapomorphy is called into question by the bilayered acrosome, with a perforatorium, in Scutigera (Mazzini et al., 1992). Of the characters noted above, only the presence of median eyes (known for fossil chelicerates and insects) is likely to be determinable in fossils being evaluated as stem-group myriapods (whereas absence of median eyes seems impossible to establish definitively in a fossil myriapod). Discussion below considers positive characters rather than absences.

\section{Tentorial bars and tentorial mobility}

Structural details of the cephalic endoskeleton and its functional role in mandibular movements provide the most compelling evidence for myriapod monophyly.

The tentorial cephalic endoskeleton is restricted to myriapods and hexapods. In myriapods, the tentorium includes so-called head apodemes (ectodermal invaginations of the premandibular region) as well as a complex of non-invaginated arms that are fused to the head apodemes (Fig. 5). The head apodemes of Myriapoda are rods or plates homologised by Snodgrass (1950) with the anterior tentorial arms of Ectognatha, in which they likewise arise as cuticular (ectodermal) invaginations. The probability of primary homology of these structures is maintained by recent workers (Bitsch and Bitsch, 2000, 2002; Koch, 2000, 2003; Klass and Kristensen, 2001). The positioning of the invagination site in Chilopoda and Symphyla was described by Koch (2001) as shared with Hexapoda, though Bitsch and Bitsch (2002) indicated that the head apodemes of myriapods have their anterior point of invagination more medial than that of the anterior tentorial pits in insects.

The detailed relationships of the anterior tentorial arms exhibit a common pattern in the Myriapoda. In particular, the head apodemes ('posterior process of the tentorium': Koch, 2003) in the Chilopoda as well as the Progoneata are fused to a transverse bar (Bitsch and Bitsch, 2002; Koch, 2003: "fultural sclerites" of Snodgrass, 1950, 1952), which may extend to the lateral cranial wall (tb in Fig. 5). The posterior processes are also merged with sclerites 

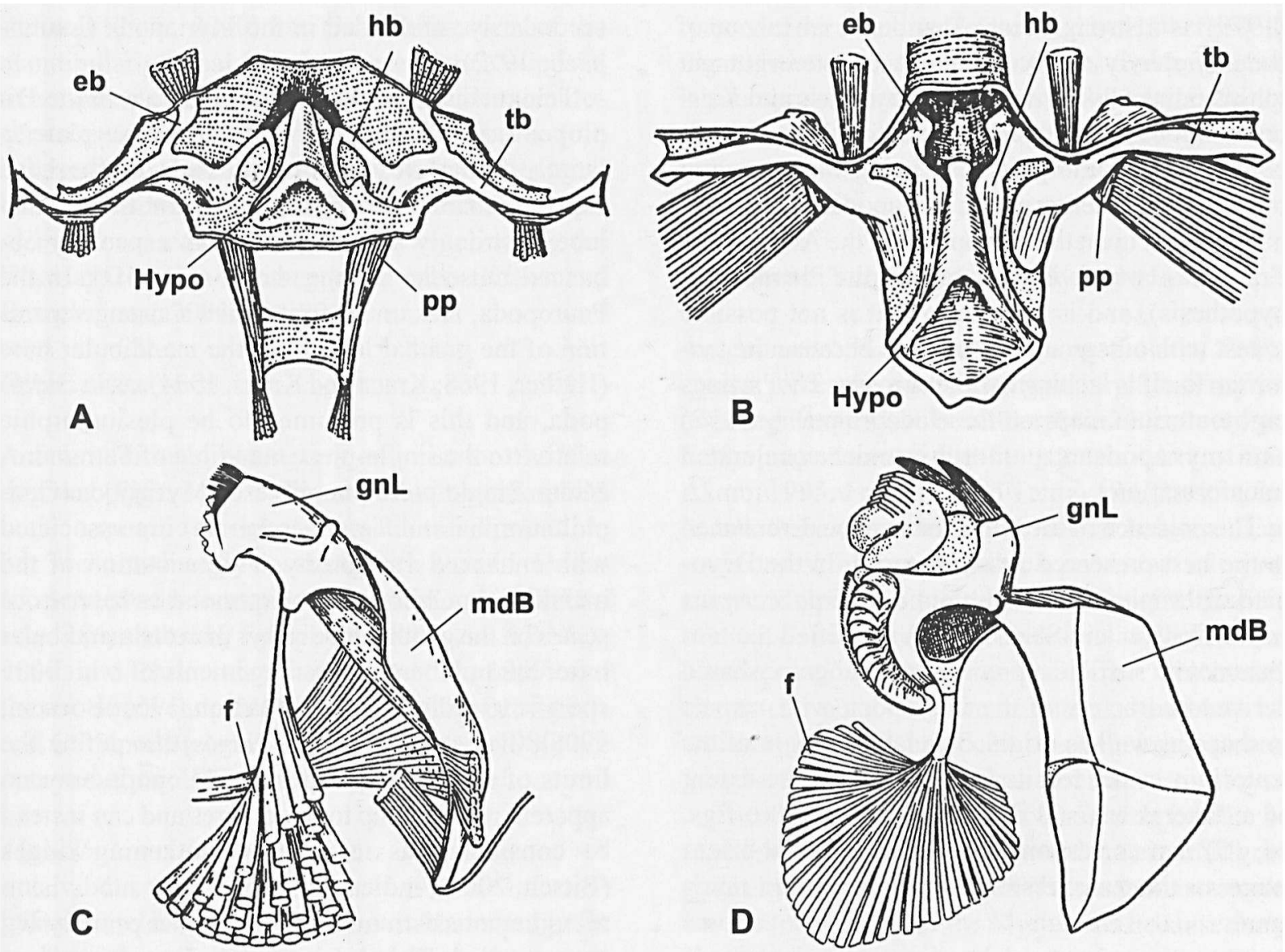

Fig. 5. Apomorphic similarities in the tentorial cephalic endoskeleton (A-B) and mandible (C-D) in Chilopoda and Diplopoda (from Snodgrass, 1950, 1952). A, C, Lithobius (Chilopoda: Lithobiomorpha); B, Arctobolus (Diplopoda: Spirobolida); D, 'Fontaria' (Diplopoda: Polydesmida). Abbreviations (after Koch, 2003): eb; epipharyngeal bar; f, gnathal lobe flexor; gnL, gnathal lobe; pp, posterior process of tentorium (=head apodeme of Snodgrass); hb, hypopharyngeal bar; Hypo, hypopharynx; mdB, mandibular base; tb, transverse bar (= fulturae of Snodgrass).

that form a hypopharyngeal bar (hb in Fig. 5), and serve as supports for the hypopharynx. An epipharyngeal bar (eb in Fig. 5) serves as the articulation of the mandible in the Chilopoda and the Symphyla (Koch, 2003). The similarity in the transverse bar was thought by Snodgrass (1952) to provide a "strong point in evidence of a relationship" between the Diplopoda, Pauropoda and Chilopoda. In each case, the transverse bar supports the apodemes that give rise to mandibular adductor muscles. Symphyla possess typically myriapodan posterior processes but were thought by Snodgrass (1950, 1952) to lack the transverse bar. However, the transverse apophysis shown by Ravoux (1975) in Scutigerella is the homologue of transverse bar in other myriapods (Bitsch and Bitsch, 2002). As such, the transverse bar is a general character for Myriapoda, except for Geophilomorpha (Koch, 2003), and a homologue is not known in Hexapoda or Crustacea. The transverse bar maps on the cladogram (Figs. 1,2 ) as a myriapod autapomorphy.

In addition to the particular sclerites that merge with the anterior tentorial arms in myriapods, the functional role of the tentorium in myriapods differs from that of hexapods in a fundamental manner. In Myriapoda, movements of the tentorial apodemes serve to abduct the mandibles, accompanied by a shift of the dorsoventral mandibular muscles to the tentorial apodeme. These tentorial movements were judged by Manton (1964) and Boudreaux 
(1979) as a strong point of evidence in favour of the monophyly of Myriapoda. A counterargument to this point of view was raised by Klass and Kristensen (2001) in the belief that tentorial movements could be plesiomorphic, i.e., being the precursor of an immobile tentorium in Hexapoda. That theory is dependent upon the monophyly of the Atelocerata/ Tracheata (which is disputed by the Tetraconata hypothesis), and is a scenario that is not possible to test with out-group comparison because the tentorium itself is lacking in other groups. The 'swinging' tentorium maps on the cladogram (Figs. 1, 2) as a myriapod aufapomorphy under accelerated transformation.

The presence of the tentorium can be determined in the best preserved fossil material. In the Devonian arthropleurid-like diplopod Microdecemplex rolfei, Wilson and Shear (2000) identified the tentorium with sufficient precision to recognise shared derived characters of the Diplopoda with respect to shape as well as origin. The lateral origin of the tentorium in the fossils. is indicated by the extent of a "lateral bar" (Wilson and Shear, 2000: figs. $14,15)$ that corresponds in its position and orientation to the transverse bar in crown-group myriapods.

\section{Separated, independently musculated gnathal lobe}

As discussed above, a gnathobasic mandible is an apomorphic character for the taxon Mandibulata (=Myriapoda + Tetraconata). Elaboration of the basic mandible with respect to structure and musculation is observed in the Myriapoda.

Most significant is the division of myriapod mandibles into an independently musculated gnatha lobe and a base plate, the latter subdivided in Hexamerocerata and Diplopoda, a condition that has been described as a telognathic mandible. Some workers (Kraus and Kraus, 1996; Kukalová-Peck 1998) have argued that telognathy (with the mandibular base including a cardo and stipes that correspond to podomeres) is more generally shared between myriapods and hexapods, but the evidence for telognathy in Hexapoda was criticised by Staniczek (2000) and Bitsch (2001). The conclusion of these studies is that mandibles are simply gnathobasic in the ground pattern of the Mandibulata, and are secondarily subdivided in the Myriapoda (Lauterbach, 1972).

Telognathy is perhaps most elaborate in the Diplopoda, in which the mandibular base plate is largely immobile, forming the side of the head capsule (shared with Symphyla), and the gnathal lobe is strongly separated, with an especially enhanced muscular independence (Fig. 5D). In the Pauropoda, Hexamerocerata have a strong separation of the gnathal lobe from the mandibular base (Hüther, 1968; Kraus and Kraus, 1994), as in Diplopoda, and this is presumed to be plesiomorphic relative to the single-piece mandible of Tetramerocerata. Single-piece mandibles in Myriapoda (Geophilomorpha and Tetramerocerata) are associated with enhanced entognathy. Fragmentation of the mandible in Chilopoda is expressed as a series of scutes on the gnathal lobe rather than the mandibular base, the numbers and arrangements of which are specific to ordinal groups (Manton, 1965; Borucki, 1996). The sutures/internal ridges that define the limits of mandibular scutes in Chilopoda have no apparent relationship to podomeres and can instead be considered as internal strengthening ridges (Bitsch, 2001), indicating a secondary subdivision of a gnathobasic mandible rather than primary leg segmentation. The primitive state for myriapods is likely a bipartite mandible composed of the base plate and gnathal lobe (Koch, 2003).

The separation of the gnathal lobe in Myriapoda has a characteristic pattern of musculation (Fig. 5CD). Chilopoda (Fig. 5C), Diplopoda (Fig. 5D), and Symphyla share the gnathal lobe musculated by a large flexor that arises in a common position on the dorsal surface of the cranium (Snodgrass, 1950; Kluge, 1999). The dorsal muscles of hexapods and crustaceans do not serve as gnathal lobe flexors. Traditionally this difference has been ascribed to the dorsal remotor, rather than the dorsal promotor, forming the cranial adductor (Manton, 1964). The view that the mandibular flexor is derived from extrinsic limb musculature has, however, been questioned by Koch (2003), who noted that an origin as endite musculation cannot be ruled out.

Though fossils will lack preservation of the mandibular musculature, the separation of the gnathal lobe can be determined in well preserved material. The arthropleurid-like Microdecemplex rolfei (Wil- 
son and Shear, 2000) has clear delineation of the mandibular gnathal lobe and base plate ("stipes"), in a manner comparable to Diplopoda, Hexamerocerata, and Symphyla. The gnathal lobe has an enlarged apodeme that certainly indicates its muscular independence. The arthropleurid Eoarthropleura devonica has a large condyle delimiting the basal articulation of its gnathal lobe (Kraus and Brauckmann, 2003: fig. 22).

\section{Other characters}

A few additional characters optimise on the cladogram (Figs. 1, 2) as myriapod autapomorphies under a specific model of character transformation, but are not directly testable with fossils. Under accelerated transformation, sperm dimorphism (character 286) shared by Symphyla (Dallai and Afzelius, 2000) and Chilopoda (Carcupino et al., 1999) and the axonemal endpiece plume shared by Pauropoda and Chilopoda (character 298: Jamieson, 1986) are autapomorphic for the Myriapoda.

\section{Mandibular comb lamellae}

Distally (relative to the mouth) on the mandibular gnathal edge, chilopods and diplopods share a series of multiple, imbricate, hyaline lamellae (comb or pectinate lamella). Multiple lamellae are present at the crown node of both the Chilopoda [present in Scutigeromorpha (Fig. 4F) and Pleurostigmophora] and the Diplopoda (present in Penicillata and Chilognatha: Fig. 4E). These comb lamellae are sufficiently similar in their positioning and details as to posit primary homology (Edgecombe and Giribet, 2002), and corresponding structures are not in the same position in crustaceans or hexapods. Some insects possess comb-like elements on the maxillary endites (Arens, 1994), but these do not share the more detailed topological correspondence observed in myriapods. The strongest counterargument against comb lamellae as a myriapod autapomorphy is their absence in Symphyla (Richter et al., 2002), and in the present dataset they are optimised as independently evolved in the Diplopoda and the Chilopoda. A more decisive answer to the question of homology would be provided by restudy of the "lamellenartige Chitinstruktur des Pha- rynx oder der Mandibel" described by Hüther (1968, Fig. 8) in hexamerocerate pauropods. Comb lamellae in pauropods would make a loss in Symphyla equally parsimonious as independent gains in chilopods and diplopods.

\section{"Tracheate" characters in Myriapoda}

Acceptance of a crustacean-hexapod clade, Tetraconata, forces the putative synapomorphies of myriapods and hexapods to be reinterpreted as convergent. Early proponents of the Tetraconata (Averof and Akam, 1995; Friedrich and Tautz, 1995) attempted to link these characters to terrestrial habits and, in some cases, this is a plausible a posteriori interpretation. Malpighian tubules, tracheae, and absence of exopods can be related to terrestrialisation. Similar a posteriori interpretations of other "tracheate" characters, notably the tentorium and limbless intercaläry segment / association of the tritocerebral ganglia in the brain, are less obvious.

The traditional Tracheata characters cannot be readily dismissed from the ground pattern of Myriapoda; indeed, acceptance of Tetraconata strengthens the monophyly of the Myriapoda because these characters serve as potential autapomorphies. Characters with this distribution, potential autapomorphies of Myriapoda under the Tetraconata hypothesis (Paulus, 2000), include: a limbless intercalary segment in the head; the association of the tritocerebral ganglia with the brain, with nerves to the labrum and frontal ganglion; the mandible lacking a palp; pretarsal segment of the legs with a single muscle, a depressor; cuticular anterior tentorial apodemes; postantennal (Tömösváry) organs; ectodermallyderived Malpighian tubules; absence of midgut glands; tracheae. These characters can be optimised as present at the crown node of the Myriapoda, with the possible exception of tracheae, for which the evidence of primary homology of all occurrences in the Myriapoda is inconclusive (see Hilken, 1998, for arguments in defense of convergent origins of myriapod tracheae; Klass and Kristensen, 2001, for a defense of tracheal homology). 


\section{Tagmosis: long-bodied fossils}

Budd et al. (2001) struggled with the question of whether the euarthropod ground pattern involved a serially homonymous, multisegmented body. This issue is brought to the forefront by fossils such as Xanthomyria Budd et al., 2001, and Pseudoiulia Hou and Bergström, 1998, which have very elongate, homonymous trunks. However, comparison of myriapod-like fossils and the euarthropod ground pattern (Budd et al., 2001) is influenced by an assumption that myriapods are basal euarthropods. In the context of the Mandibulata hypothesis, an especially elongate trunk is not necessarily (or even probably) associated with the myriapod ground pattern.

For the myriapod crown-group at least, the question of trunk segmentation can be addressed. Chilopoda have 15 post-maxillipede leg pairs at the crown node. This number is shared and invariant in the Scutigeromorpha, Lithobiomorpha and Craterostigmus, and is optimised as the basal state in Chilopoda and Pleurostigmophora (Minelli et al., 2000). Trunk segment numbers in Progoneata likewise indicate that the crown node involves only a moderate numer of segments. Symphyla have 12 trunk leg pairs and Pauropoda have 9-11. The diplopod ground pattern involves comparable segmentation to other progoneates. Penicillata, sister group of all other Diplopoda, have 11-17 trunk leg pairs (Enghoff et al., 1993). The escalation of trunk segment numbers within the Helminthomorpha (Diplopoda) and Geophilomorpha (Chilopoda) are apomorphic states, neither retentions from the myriapod ground pattern nor from the euarthropod ground pattern. As such, large trunk segment numbers in fossil taxa such as Xanthomyria and Pseudoiulia do not provide evidence for an especially close relationship to Myriapoda.

\section{Fossil candidates for the stem-group?}

The argument for fossils being allied to the Myriapoda has generally emphasised a lack of post-cephalic tagmosis and uniramous appendages. Given that the former state is a symplesiomorphy (Dohle, 1980) and the latter homoplastic with uniramy in hexa- pods (according to the phylogenetic hypothesis in Figs. 1 and 2), these characters are not profoundly informative.

The earliest well-corroborated Myriapoda in the fossil record (Fig. 6) are members of the crowngroup rather than parts of the stem-group. A species from the Stonehaven Group, Scotland (late-Wenlock-early Ludlow: Wilson and Anderson, 2004), was recognised by Almond (1985) as a definite member of the Diplopoda. The Stonehaven taxa Cowiedesmus, Albadesmus and Pneumodesmus were all assigned by Wilson and Anderson (2004) to the Archipolypoda, along with the Lower Devonian Archaedesmida and Upper Carboniferous Euphoberiida. Cowiedesmus has modified anterior trunk appendages that may represent gonopods (Wilson and Anderson, 2004), a character conventionally considered to diagnose the long-bodied millipedes, the Helminthomorpha. The mid Silurian members of the Archipolypoda date the crown-group for the Chilognatha, and probably Helminthomorpha, to a minimal age of late Wenlock-early Ludlow. By extension, the crown groups for the Diplopoda, Dignatha, Progoneata, and Myriapoda (Fig. 3) have a minimal age at least this old (Fig. 6).

Arthropleurids, formerly placed in various positions in or allied to the Myriapoda, are now established as members of the Diplopoda (Wilson and Shear, 2000; Kraus and Brauckmann, 2003). The Upper Silurian (Přidolí)-Upper Devonian Eoarthropleura (Størmer, 1976; Shear and Selden, 1995) and the Carboniferous-Lower Permian Arthropleura comprise the Arthropleurida sensu Kraus and Brauckmann, 2003. These taxa share several apomorphic characters with the extant polyxenid millipedes, the Penicillata (Kraus and Brauckmann, 2003). The Middle-Upper Devonian genus Microdecemplex has been considered an arthropleurid (Wilson and Shear, 2000), but this is disputed by Kraus and Brauckmann (2003), who allow that it may be more closely related to Chilognatha. Either interpretation nests the Arthropleurida within the clades Progoneata, Dignatha and Diplopoda, such that they are not particularly germane to questions concerning the myriapod stem-group.

The earliest known centipedes (Fig. 6) are also nested within the crown-group of Chilopoda. The record for Scutigeromorpha has been extended back 


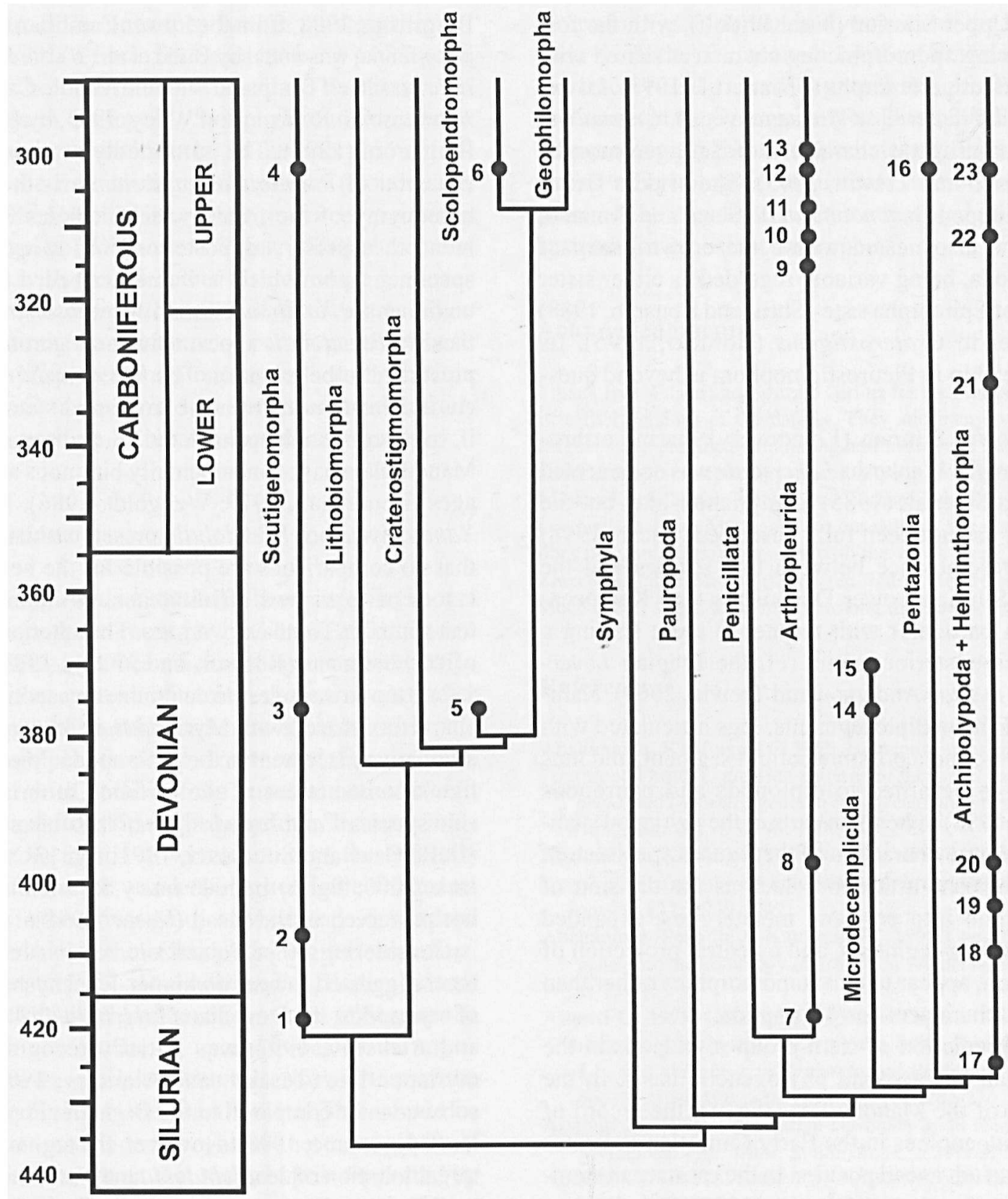

Fig. 6. Phylogeny of Myriapoda with minimal divergence dates calibrated by Silurian - Carboniferous fossil occurrences. Phylogenetic position of Arthropleurida and Microdecemplicida follows Kraus and Brauckmann (2003). Archipolypoda is as delimited by Wilson and Anderson (2004). Numbers refer to records as follow: 1-3. Crussolum spp. (Shear et al., 1998; Anderson and Trewin 2003); 4. Latzelia (Mundel, 1979); 5. Devonobius (Shear and Bonamo, 1988); 6. Mazoscolopendra (Mundel, 1979); 7-8. Eoarthropleura spp. (Shear and Selden, 1995); 9-13. Arthropleura spp. (Hahn et al., 1986; Briggs and Almond, 1994; Hannibal, 1997, and references therein); 14-15. Microdecemplex (Wilson and Shear, 2000); 16. Amynilyspes, Archiscudderia, Glomerospis (Hannibal and Feldmann, 1981); 17. Albadesmus, Cowiedesmus, Pneumodesmus (Wilson and Anderson, 2004); 18. Archidesmus (Wilson and Anderson, 2004); 19. Palaeodesmus (Wilson and Anderson, 2004); 20. Unnamed species (Shear et al., 1996), 21. Anthracodesmus (Wilson and Anderson, 2004), unnamed species (Shear, 1994); 22. Myriacantherpestes (Burke, 1979); 23. Acantherpestes, Euphoberia, Myriacantherpestes (Burke, 1979), Xyloiulus, Nyranius, Plagiascetus (Hoffman, 1963), Pleurojulus (Kraus, 1974), Hexecontasoma (Hannibal, 2000). 
to the Upper Silurian (basal Prídolí), with the fossils having apomorphic leg characters shared with extant Scutigeromorpha (Shear et al., 1998). Lower Devonian material of the same genus, Crussolum, adds maxillipede characters of Scutigeromorpha (Anderson and Trewin, 2003). The Middle Devonian chilopod Devonobius delta Shear and Bonamo, 1988 , is also nested within the crown-group of Chilopoda, being variably regarded as either sister group of Epimorpha s.str. (Shear and Bonamo, 1988) or sister to Craterostigmus (Borucki, 1996). Its membership in Pleurostigmophora is beyond question.

A Lower Silurian (Llandovery) marine arthropod from the Waukesha Lagerstatte was documented by Mikulic et al. (1985) as myriapod-like, but the species has not been fully described. Shear (1998) noted resemblance between this species and the Upper Silurian-Lower Devonian group Kampecarida, in particular with respect to them sharing a limbless posterior tagma (cf. the Pragian Leverhulmia mariae Anderson and Trewin, 2003). Kampecarids have diplosegments, legs articulated with the sterna, and a possible collum segment, and thus appear to be allied to diplopods and pauropods (Shear, 1998) rather than parts of the myriapod stemgroup. Some characters of the figured specimen of the Waukesha arthropod, such as the division of the tergum into pre- and metatergites, expanded proximal leg segments, and a ventral projection of the telson, appear to be autapomorphies rather than general characters for Myriapoda.

The prediction of stem-group myriapods in the Cambrian has a sound phylogenetic basis. In the context of the Mandibulata (Fig. 1), the record of phosphatocopines in the Early Cambrian indicates taxa in an advanced position in the crustacean stemgroup by that time (Walossek, 1999). This implies that the divergence of the Myriapoda from the Tetraconata (or between Crustacea and Tracheata) dates at least to the Early Cambrian. A few Cambrian arthropods have been compared to myriapods in recent literature, all of these taxa sharing a serially homonymous trunk with a large number of tergites, a pattern that is also found within the crown group of Crustacea in remipedes. Resemblance between the Upper Cambrian Xanthomyria Budd et al. 2001, and Pseudoiulia cambriensis Hou and
Bergström, 1998, from the Lower Cambrian Chengjiang fauna, was noted by Budd et al. (2001). Pseudoiulia was itself compared with the Middle Cambrian Meristosoma Robison and Wiley, 1995, by Hou and Bergström (1998). The purportedly myriapod-like character of Pseudoiulia cambriensis is the serial homonymy of the trunk, which includes 32 segments in its preserved (posterior) portion in the sole specimen upon which it was described. Legs are unknown for Xanthomyria and Meristosoma, whilst those of Pseudoiulia appear to have setigerous flaps, presumed to be exopods. The latter would not exclude Pseudoiulia from the myriapod stem-group if, as is commonly considered, Euarthropoda and Mandibulata have fundamentally biramous appendages (Boudreaux, 1979; Weygoldt, 1986). Neither Xanthomyria nor Pseudoiulia preserve a head, such that no comparisons are possible for the best indicators of myriapod affinity, i.e., the mandibles, tentorium, or Tömösváry organs. The anterior shield of Meristosoma (Robison and Wiley, 1995: figs. 1,2 ) is too structureless to determine any apomorphic characters shared with Myriapoda or to suggest an alternative placement in the Arthropoda. Myriapodlike reconstructions of the Middle Cambrian marine species Cambropodus gracilis Robison, 1990 (Delle Cave and Simonetta, 1991: fig. 13C; Retallack, 2000: fig. 6) include many features that are not preserved in the fossil (Shear, 1998).

Considering other Palaeozoic fossils that have been suggested to bear on higher-level systematics of myriapods, the Devonian Maldybulakia Tesakov and Alekseev, 1997, was initially recognised as myriapod-like (Tesakov and Alekseev, 1992) and subsequently compared to the Dignatha in particular (Edgecombe, 1998). However, the tagmosis and tergal lobation of Maldybulakia may be more compatible with those seen in certain aberrant chelicerates, such as the synziphosuran Willwerathia (Anderson et al., 1998). This is an indication of the limits of tergal material when attempting to identify problematic arthropods as myriapods. Tergal characters provide strong apomorphies for membership in clades within Myriapoda, e.g., heterotergy with an alternation in tergite lengths between pedigerous segments seven and eight in Chilopoda; diplotergy in Diplopoda, and calcification in Chilognatha, but tergal apomorphies for Myriapoda as a 
whole are difficult to specify. The paratergal lobes may provide a basis for characterising Myriapoda that can be determined in fossils. The absence of paraterga in Chilopoda, Symphyla and Pauropoda has been considered to be an apomorphic reduction in the myriapod ground pattern (Boudreaux, 1979), though this interpretation forces paraterga in diplopods (Wilson and Shear, 2000) to be convergent with those in other arthropods, e.g., hexapods, crustaceans, trilobites. Still, fit to the tree (Figs. 1-3) optimises an absence of paraterga at the base of the myriapod crown-group, and a lack of paraterga in a fossil taxon would be consistent with an advanced position on the myriapod stem-group.

\section{Conclusions}

Morphological data that have been cited in support of myriapod non-monophyly (Kraus, 2001; Loesel et al., 2002) have been included in the current analysis. In the context of more exhaustive character sampling; Myriapoda unites as a clade, with particular support from the structure of the mandible, together with details of the tentorial endoskeleton and its relationship to the mandible. In those midPalaeozoic fossils in which some of these details can be observed, evidence is available for membership in the crown-group of Myriapoda, and indeed membership within Chilopoda, e.g., Devonobius, or Diplopoda, e.g., Microdecemplex. Earlier Palaeozoic fossils that have been compared to Myriapoda possess no convincing apomorphies of the myriapod crown-group or even the crown-group of the more inclusive clade Mandibulata. This cannot be construed as evidence against the monophyly of Mandibulata, given that the group is supported by detailed similarity in extant members, whereas the Early Palaeozoic fossils in question are poorly known. From the kinds of characters that provide the data in defense of myriapod monophyly, as based on extant arthropods, it seems that interpreting Early Palaeozoic fossils as stem-group myriapods will require truly exceptional preservation. This is not meant to discourage the search, since all competing theories of arthropod phylogeny predict stemgroup myriapods before the Silurian. Indeed, the best supported phylogeny based on the extant Ar- thropoda (Fig. 1) demands divergence of the Myriapoda from the Tetraconata by the Cambrian, and the trace fossil record suggests the presence of myriapods in the Ordovician (Retallack, 2000, 2001). Assignments to the myriapod stem-group require strong morphological arguments and a consideration of the character evidence that underpins the systematics of extant arthropods.

\section{Acknowledgments}

I thank Buz Wilson and Gonzalo Giribet for their collaboration in earlier versions of the dataset. They and many other colleagues have provided stimulating and instructive discussions about arthropod morphology. Shane Ahyong, Wolfgang Dohle, Markus Koch, Stefan Richter, and Gerhard Scholtz have been especially helpful. My thanks for our debates and discussions does not imply their agreement with the views herein. Yongyi Zhen (Australian Museum) prepared figures. The referees provided useful suggestions for improving the manuscript.

\section{References}

Abzhanov A, Kaufman TC. 1999. Homeotic genes and the arthropod head: expression patterns of the labial, prosboscipedia, and Deformed genes in crustaceans and insects. Proc. Natl. Acad. Sci. USA 96: 10224-10229.

Abzhanov A, Kaufman TC. 2000. Crustacean (malacostracan) Hox genes and the evolution of the arthropod trunk. Development 127: 2239-2249.

Abzhanov A, Popadić A, Kaufman TC. 1999. Chelicerate $H o x$ genes and the homology of arthropod segments. Evol. Dev. 1: $77-89$.

Alberti G. 1995. Comparative spermatology of Chelicerata: review and perspective. In: Jamieson, BGM, Ausio J, Justone $\mathrm{J}-\mathrm{L}$, eds. Advances in Spermatozoal Phylogeny and Taxonomy. Mém. Mus. natl. Hist. nat. 166: 203-230.

Almond JE. 1985. The Silurian-Devonian fossil record of the Myriapoda. Phil. Trans. R. Soc. Lond. B 309: 227-237.

Anderson DT. 1973. Embryology and Phylogeny in Annelids and Arthropods. Oxford: Pergamon Press.

Anderson DT. 1979. Embryos, fate maps, and the phylogeny of arthropods. In: Gupta AP, ed. Arthropod Phylogeny. New York: Van Nostrand Reinhold, 59-105.

Anderson LI, Poschmann M, Brauckmann C. 1998. On the Emsian (Lower Devonian) arthropods of the Rhenish Slate Mountains: 2. The synziphosurine Willwerathia. Paläontol. Z. 72: 325-336.

Anderson LI, Selden P. 1997. Opisthosomal fusion and phylogeny of Palaeozoic Xiphosura. Lethaia 30: 19-31.

Anderson LI, Trewin NH. 2003. An Early Devonian arthropod fauna from the Windyfield Cherts, Aberdeenshire, Scotland. Palaeontol. 46: 467-509. 
Arens W. 1994. Striking convergence in the mouthpart evolution of some stream-living algae grazers. J. Zool. Syst. Evol. Research 32: 319-342.

Attems CG. 1926. Chilopoda. In: Kükenthal W, Krumbach T, eds. Handbuch der Zoologie. Eine Naturgeschichte der Stamme des Tierreiches. Berlin, Leipzig: Walter de Gruyter, 17-402.

Attems CG 1930. Myriapoda 2. Scolopendromorpha. In Schulze FE, Kükenthal W, eds. Das Tierreich, 54. Berlin Walter de Gruyter, 1-308.

Averof M, Akam M. 1995. Insect-crustacean relationships: insights from comparative developmental and molecular studies. Phil. Trans. R. Soc. London, Biol. Sci. B347: 293303.

Ax P. 1999. Das System der Metazoa II. Ein Lehrbuch der phylogenetischen Systematik. Stuttgart: Gustav Fischer Verlag.

Baccetti B, Burrini AG, Dallai R, Pallini V. 1979. Recent work in myriapod spermatology (The spermatozoon of Arthropoda XXXI). In: Camatini, M., ed. Myriapod Biology. London: Academic Press, 97-104.

Baccetti B, Dallai R. 1978. The evolution of myriapod spermatozoa. Abh. Verh. naturwiss. Ver. Hamburg 21/22: 203-217.

Barth FG. 1985. Slit sensilla and the measurement of cuticular strains. In: Barth FG, ed. Neurobiology of Arachnids. Berlin: Springer-Verlag, 162-188.

Bergström J, Stürmer W, Winter G. 1980. Palaeoisopus, Palaeopantopus and Palaeothea, pycnogonid arthropods from the Lower Devonian Hunsrück Slate, West Germany. Paläont. Z. 54: 7-54.

Beutel RG, Gorb SN. 2001. Ultrastructure of attachment specializations of hexapods (Arthropoda): evolutionary patterns inferred from a revised ordinal phylogeny. J. Zool. Syst. Evol. Research 39: 177-207.

Bitsch J. 2001. The arthropod mandible: morphology and evolution. Phylogenetic implications. Ann. Soc. Entomol. Fr. (N.S.) 37: 305-321.

Bitsch C, Bitsch J. 1998. Internal anatomy and phylogenetic relationships among apterygote insect clades (Hexapoda). Ann. Soc. Entomol. Fr. (N.S.) 34: 339-363.

Bitsch C, Bitsch J. 2000. The phylogenetic interrelationships of the higher taxa of apterygote hexapods. Zool. Scriptq 29: 131-156.

Bitsch C, Bitsch J. 2002. The endoskeletal strauctures in arthropods: cytology, morphology and evolution. Arthropod Struct. Dev. 30: 159-177.

Bonato L, Minelli A. 2002. Parental care in Dicellophilus carniolensis (C. L. Koch, 1847): new behavioural evidence with implications for the higher phylogeny of centipedes (Chilopoda). Zool. Anz. 241: 193-198.

Boore JL, Collins TM, Stanton D, Daehler LL, Brown WM. 1995. Deducing the pattern of arthropod phylogeny from mitochondrial DNA rearrangements. Nature 376: 163-165.

Boore JL, Lavrov DV, Brown WM. 1998. Gene translocation links insects and crustaceans. Nature 392: 667-668.

Borucki H. 1996. Evolution und phylogenetisches system der Chilopoda (Mandibulata, Tracheata). Verh. naturwiss. Ver. Hamburg 35: 95-226.
Boudreaux HB. 1979. Arthropod Phylogeny with Special Reference to Insects. New York: J. Wiley \& Sons.

Boxshall G. 1998. Comparative limb morphology in major crustacean groups: The coxa-basis joint on postmandibular limbs. In: Fortey RA, Thomas RH, eds. Arthropod Relationships. London: Chapman \& Hall, 155-167.

Bremer K. 1994. Branch support and tree stability. Cladistics 10: $295-304$.

Briggs DEG, Almond JE. 1994. The arthropleurids from the Stephanian (Late Carboniferous) of Montceau-les-Mines. In: Poplin C, Heyler D, eds. Quand le Massif Central était sous l'équateur: un écosystème Carbonifère à Montceaules-Mines. Mém. Sec. Sci. 12. Paris: Comité des Travaux Historiques et Scientifiques, 127-135.

Budd GE. 1998. Stem group arthropods from the Lower Cambrian Sirius Passet fauna of North Greenland. In: Fortey RA, Thomas RH, eds. Arthropod Relationships. London: Chapman \& Hall, 125-138.

Budd GE. 1999. The morphology and phylogenetic significance of Kerygmachela kierkegaardi Budd (Buen Formation, Lower Cambrian, N Greenland). Trans. R. Soc. Edinburgh: Earth Sci. 89: 249-290.

Budd GE. 2001. Tardigrades as 'stem-group arthropods': the evidence from the Cambrian fauna. Zool. Anz. 240: 65-279.

Budd GE, Högström AES, Gogin I. 2001. A myriapod-like arthropod from the Upper Cambrian of East Siberia. Paläontol. Z. 75: 37-41.

Bullock TH, Horridge GA. 1965. Structure and Function of the Nervous System of Invertebrates, Vols. I, II. San Francisco: W. H. Freeman and Co.

Burke JJ. 1979. A new millipede genus, Myriacantherpestes (Diplopoda, Archipolypoda) and a new species Myriacantherpestes bradebirksi, from the English Coal measures. Kirtlandia 30: 1-24.

Carcupino M, Baldacci A, Fausto AM, Scapigliati G, Mazzini M. 1999. Sperm dimorphism in Chilopoda: comparison of Scolopendromorpha and Geophilomorpha. Invert. Reprod. Dev. 35: 45-53.

Cassagnau P, Juberthie C. 1983. Neurohemal organs in Apterygota. In: Gupta AP, ed. Neurohemal Organs of Arthropods: Their Development, Evolution, Structures, and Functions. Springfield: Charles C Thomas, 281-318.

Clarke KU. 1979. Visceral anatomy and arthropod phylogeny. In: Gupta AP, ed. Arthropod Phylogeny. New York: Van Nostrand Reinhold, 467-549.

Cook CE, Smith ML, Telford MJ, Bastianello A, Akam M. 2001. Hox genes and the phylogeny of the arthropods. Curr. Biol. 11: 759-763.

Crabill RE Jr. 1960. A new American genus of cryptopid centipede, with an annotated key to the scolopendromorph genera from America north of Mexico. Proc. U.S. Natl. Mus. 111: $1-15$

Crampton GC. 1921. The phylogenetic origin of the mandibles of insects and their arthropodan relatives - a contribution to the study of the evolution of the Arthropoda. J. N.Y. Entomol. Soc. 29: 63-100.

Dahms H-U. 2000. Phylogenetic implications of the crustacean nauplius. Hydrobiologia 417: 91-99. 
Dallai R, Afzelius BA. 1993. Characteristics of the sperm tail of the velvet worm, Euperipatoides leuckarti (Onychophora). Tissue Cell 25: 907-913.

Dallai R, Afzelius BA. 1999. Accessory microtubules in insect spermatozoa: structure, function and phylogenetic significance. In: Gagnon C, ed. The Male Gamete - From Basic Science to Clinical Applications. Vienna, IL: Cache River Press, 333-350.

Dallai R, Afzelius BA. 2000. Spermatozoa of the 'primitive type' in Scutigerella (Myriapoda, Symphyla). Tissue Cell 32: 18.

Dallai R, Frati F, Lupetti P, Adis J. 2003. Sperm ultrastructure of Mantophasma zephyra (Insecta, Mantophasmatodea). Zoomorphol. 122: 67-76.

Dallai R, Lupetti P, Frati F, Nardi F, Afzelius, BA. 2001. Binucleate and biflagellate spermatozoa in Tricholepidion gertschi Wygodzinsky (Insecta, Zygentoma). Tissue Cell 33: 606-613.

Damen WGM, Hausdorf M, Seyfarth E-A, Tautz D. 1998. A conserved mode of head segmentation in arthropods revealed by the expression pattern of Hox genes in a spider. Proc. Natl. Acad. Sci. USA 95: 10665-10670.

Delle Cave L, Simonetta AM. 1991. Early Palaeozoic arthropods and problems of arthropod phylogeny: with some notes on taxa of doubtful affinities. In: Simonetta AM, Conway Morris S, eds. The Early Evolution of the Metazoa and the Significance of Problematic Taxa. Cambridge: Cambridge Univ. Press, 189-244.

Delsuc F, Phillips MJ, Penny D. 2003. Comment on "Hexapod origins: monophyletic or paraphyletic?". Science 301: 1482d.

Dewel RA, Budd GE, Castano DF, Dewel WC. 1999. The organization of the subesophageal nervous system in tardigrades: insights into the evolution of the arthropod hypostome and tritocerebrum. Zool. Anz. 238: 191-203.

Dewel RA, Dewel WC. 1996. The brain of Echiniscus viridissimus Peterfi, 1956 (Heterotardigrada): a key to understanding the phylogenetic position of tardigrades and the evolution of the arthropod head. Zool. J. Linn. Soc. 116: 35-49.

Dewel RA, Dewel WC. 1998. The place of tardigrades in arthropod evolution. In: Fortey RA, Thomas RH, eds. Arthropod Relationships. London: Chapman and Hall, 109-123.

Diederich RJ, Merrill VKL, Pultz MA, Kaufman TC. 1989. Isolation, structure, and expression of labial, a homeotic gene of the Antennapedia Complex involved in Drosophila head development. Genes Dev. 3: 399-414.

Dohle W. 1980. Sind die Myriapoden eine monophyletische Gruppe? Eine Diskussion der Verwandtschaftsbeziehungen der Antennaten. Abh. naturwiss.' Ver. Hamburg 23: 45-104.

Dohle W. 1985. Phylogenetic pathways in the Chilopoda. Bijdr. Dierkunde 55: 55-66.

Dohle W. 1998. Myriapod-insect relationships as opposed to an insect-crustacean sister group relationship. In: Fortey RA, Thomas RH, eds. Arthropod Relationships. London: Chapman and Hall, 306-315.

Dohle W. 2001. Are the insects terrestrial crustaceans? A dis-" cussion of some new facts and arguments and the proposal of the proper name Tetraconata for the monophyletic unit
Crustacea + Hexapoda. In: Deuve $\mathrm{T}$, ed. Origin of the Hexapoda. Ann. Soc. Entomol. France (N. S.) 37: 85-103.

Duman-Scheel M, Patel NH. 1999. Analysis of molecular marker expression reveals neuronal homology in distantly related arthropods. Development 126: 2327-2334.

Dunlop JA. 1996. Evidence for a sister group relationship between Ricinulei and Trigonotarbida. Bull. Br. arachnol. Soc. 10: 193-204.

Dunlop JA. 1998. The origins of tetrapulmonate book lungs and their significance for chelicerate phylogeny. In: Selden PA, ed. Proceedings of the $17^{\text {th }}$ European Colloquium of Arachnology, 9-16.

Dunlop JA. 1999. A redescription of the Carboniferous arachnid Plesiosiro madeleyi Pocock, 1911 (Arachnida: Haptopoda). Trans. R. Soc. Edinburgh: Earth Sci. 90: 29. 47.

Dunlop JA, Webster M. 1999. Fossil evidence, terrestrialization and arachnid phylogeny. J. Arachnol. 27: 86-93.

Eason TH. 1964. Centipedes of the British Isles. London: Warne and $\mathrm{Co}$.

Edgecombe GD. 1998. Early myriapodous arthropods from Australia: Maldybulakia from the Devonian of New South Wales. Rec. Aust. Mus. 50: 293-314.

Edgecombe GD, Giribet G. 2002. Myriapod phylogeny and the relationships of Chilopoda. In: Llorente Bousquets J, Morrone JJ, eds̈. Biodiversidad, Taxonomia y Biogeografia de Artrópodos de México: Hacia una Síntesis de su Conocimiento. México: Prensas de Ciencias, Universidad Nacional Autómoma de México, 143-168.

Edgecombe GD, Giribet G, Wheeler WC. 1999. Filogenia de Chilopoda: combinando secuencias de los genes ribosómicos $18 \mathrm{~S}$ y $28 \mathrm{~S}$ y morfología. In: Melic A, de Haro JJ, Mendez M, Ribera I, eds. Evolución y Filogenia de Arthropoda. Bol. Soc. Entomol. Aragon. 26: 293-331.

Edgecombe GD, Richter S, Wilson GDF. (2003) The mandibular gnathal edge: Homologous structures throughout Mandibulata? In: Hamer M, ed. Proceedings of the $12^{\text {th }}$ International Congress of Myriapodology. Afr. Inverts. 44: 115-135.

Edgecombe GD, Wilson GDF, Colgan DJ, Gray MR, Cassis G. 2000. Arthropod cladistics: combined analysis of Histone $\mathrm{H} 3$ and U2 snRNA sequences and morphology. Cladistics 16: 155-203.

Eisenbeis G, Wichard W. 1985. Atlas zur Biologie der Bodenarthropoden. Berlin, Heidelberg: Springer-Verlag.

Elofsson R. 1965. The nauplius eye and frontal organs in Malacostraca (Crustacea). Sarsia 19: 1-54.

Elofsson R. 1966. The nauplius eye and frontal organs of the non-Malacostraca (Crustacea). Sarsia 25: 1-128.

Enghoff H. 1984. Phylogeny of the millipedes - a cladistic analysis. Z. Zool. Syst. Evol.-forsch. 22: 8-26.

Enghoff H, Dohle W, Blower JG. 1993. Anamorphosis in millipedes (Diplopoda) - the present state of knowledge, with some developmental and phylogenetic considerations. Zool. J. Linn. Soc. 109: 103-234.

Eriksson BJ, Budd GE. 2000. Onychophoran cephalic nerves and their bearing on our understanding of head segmentation and stem-group evolution of Arthropoda. Arthropod Struct. Dev. 29: 197-209.

Eriksson BJ, Tait NN, Budd GE. 2003. Head development in 
the onychophoran Euperipatoides kanangrensis with particular reference to the central nervous system. J. Morphol. 255: 1-23.

Fahlander K. 1938. Beiträge zur Anatomie und systematischen Einteilung der Chilopoden. Zool. Bidr. Uppsala 17: 1-148.

Fahrenbach WH. 1999. Merostomata. In: Harrison FW, Foelix RF, eds. Microscopical Anatomy of Invertebrates, Volume 8A. Chelicerate Arthropoda. New York: Wiley-Liss, 21-115.

Farris JS. 1969. A successive approximations approach to character weighting. Syst. Zool. 18: 374-385.

Farris JS, Albert VA, Källersjö M, Lipscomb A, Kluge AG. 1996. Parsimony jackknifing outperforms neighbor-joining. Cladistics 12: 99-124.

Firstman B. 1973. The relationship of the chelicerate arterial system to the evolution of the endosternite. J. Arachnol. 1: $1-54$.

Foddai D, Minelli A. 2000. Phylogeny of geophilomorph centipedes: old wisdom and new insights from morphology. In: Wytwer J, Golovatch S, eds. Progress in Studies on Myriapoda and Onychophora. Fragm. faun. Suppl. 43: 6171.

François J. 1969. Anatomie et morphologie céphalique des protoures (Insecta Apterygota). Mém. Mus. natn. Hist. nat. Paris A 59: 1-144.

Friedrich M, Tautz D. 1995. Ribosomal DNA phylogeny of the major extant arthropod classes and the evolution of myriapods. Nature 376: 165-167.

Friedrich M, Tautz D. 2001. Arthropod rDNA phylogeny revisited: a consistency analysis using Monte Carlo simulation. In: Deuve T, ed. Origin of the Hexapoda. Ann. Soc. Entomol. France (N. S.) 37: 21-40.

Füller H. 1960. Untersuchungen über den Bau der Stigmen bei Chilopoden. Zool. Jahrb. (Anat.) 78: 129-144.

Fürst von Lieven A. 2000. The transformation from monocondylous to dicondylous mandibles in the Insecta. Zool. Anz. 239: 139-146.

Gabe M. 1972. Contribution à l'histologie du rein maxillaire des Chilopodes. Ann. Sci. Nat. Zool. 14: 105-129.

Gauthier J, Kluge AG, Rowe T. 1988. Amniote phylogeny and the importance of fossils. Cladistics 4: 105-209.

Gerberding M. 1997. Germ band formation and early neurogenesis of Leptodora kindti (Cladocera): first evidence for neuroblasts in the entomostracan crustaceans. Invert Reprod. Dev. 32: 63-73.

Gereben-Krenn B-A, Pass G. 1999. Circulatory organs of Diplura (Hexapoda): the basic design in Hexapoda? Intl. J. Insect Morphol. Embryol. 28: 71-79.

Giribet G, Carranza S, Baguñà J, Ruitort $M$, and Ribera $C$. 1996. First molecular evidence for the existence of a Tardigrada + Arthropoda clade. Mol. Biol. Evol. 13: 76-84.

Giribet G, Edgecombe GD, Wheeler WC. 2001. Arthropod phylogeny based on eight molecular loci and morphology. Nature 413: 157-161.

Giribet G, Edgecombe GD, Wheeler WC, Babbitt C. 2002. Phylogeny and systematic position of Opiliones: a combined analysis of chelicerate relationships using morphological and molecular data. Cladistics 18: 5-70.

Giribet G, Ribera C. 1998. The position of arthropods in the animal kingdom: a search for a reliable outgroup for internal arthropod phylogeny. Mol. Phylog. Evol. 9: 481-488.

Giribet G, Ribera C. 2000. A review of arthropod phylogeny: new data based on ribosomal DNA sequences and direct character optimization. Cladistics 16: 204-231.

Goloboff PA. 1998. NONA Version 2.0. New York: Amer. Mus. Nat. Hist.

Goodwin TW. 1960. Biochemistry of pigments. In: Waterman TH, ed. The Physiology of Crustacea. I. Metabolism and Growth. New York, London: Academic Press, 101-140.

Grenier JK, Garber TL, Warren R, Whitington PM, Carroll S. 1997. Evolution of the entire arthropod Hox gene set predated the origin and radiation of the onychophoran/arthropod clade. Current Biol. 7: 547-553.

Gupta AP. 1983. Neurohemal and neurohemal-endocrine organs and their evolution in arthropods. In: Gupta AP, ed. Neurohemal Organs of Arthropods. Their Development, Evolution, Structures, and Functions. Springfield: Charles C Thomas, 17-50.

Hackman RH. 1984. Cuticle: Biochemistry. In: Bereiter-Hahn J, Matoltsy AG, Sylvia Richards K, eds. Biology of the Integument. 1. Invertebrates. Berlin: Springer-Verlag, 583-610.

Hahn G, Hahn R, Brauckmann C. 1986. Zur Kenntnis von Arthropleura (Myriapoda; Ober-Karbon). Geol. Paleontol. 20: $125-137$.

Hannibal JT. 1997. Remains of Arthropleura, a gigantic myriapod arthropod, from the Pennsylvanian of Ohio and Pennsylvania. Kirtlandia 50: 1-9.

Hannibal JT. 2000. Hexecontasoma, a new helminithomorph millipede (Hexecontasomatidae $\mathrm{n}$. fam.) from the Mazon Creek, Illinois, fauna (Carboniferous, North America). In: Wytwer J, Golovatch S, eds. Progress in Studies on Myriapoda and Onychophora. Fragm. faun. Suppl. 43: 19. 35.

Hannibal JT, Feldmann RM. 1981. Systematics and functional morphology of oniscomorph millipeds (Arthropoda: Diplopoda) from the Carboniferous of North America. $J$. Paleontol. 54: 730-746.

Hanström B. 1934. Bemerkungen über das Komplex-Auge der Scutigeriden. Lunds Univ. Arks. 30: 1-13.

Harvey MS, Yen AL. 1989. Worms to Wasps. An Illustrated Guide to Australia's Terrestrial Invertebrates. Melbourne: Oxford Univ. Press.

Haupt J. 1979. Phylogenetic aspects of recent studies on myriapod sense organs. In: Camatini M, ed. Myriapod Biology. London: Academic Press, 391-406.

Hennig W. 1969. Der Stammegeschichte der Insekten. Frankfurt: Verlag W. Kramer.

Hennig W. 1972. Taschenbuch der Speziellen Zoologie. Teil 2. Wirbellose II. Gliedertiere. Frankfurt/Main, Zürich: Verlag Harri Deutsch.

Herbst C. 1891. Beiträge zur Kenntnis der Chilopoden. Bibl. Zool. 3: $1-42$.

Hessler RR. 1992. Reflections on the phylogenetic position of the Cephalocarida. Acta Zool. 73: 315-316.

Hilken G. 1997. Tracheal systems in Chilopoda: A comparison under phylogenetic aspects. Entomol. Scand. Suppl. 51: 4960. 
Hilken G. 1998. Vergleich von Tracheensystemen unter phylogenetischen Aspekt. Verh. naturwiss. Ver. Hamburg 37: 5-94.

Hilken G, Kraus O. 1994. Struktur und Homologie der Komponenten des Gnathochilarium der Chilognatha (Tracheata, Diplopoda). Verh. naturwiss. Ver. Hamburg 34: 33-50.

Hoffman R. 1963. New genera and species of Upper Paleozoic Diplopoda. J. Paleontol. 37: 167-174.

Hou X-G, Bergström J. 1998. Three additional arthropods from the Early Cambrian Chengjiang fauna, Yunnan, southwest China. Acta Palaeontol. Sinica 37: 395-401.

Hughes CL, Kaufman TC. 2002a. Exploring the myriapod body plan: expression patterns of the ten Hox genes in a centipede. Development 129: 1225-1238.

Hughes CL, Kaufman TC. 2002b. Hox genes and the evolution of the arthropod body plan. Evol. Dev. 4: 459-499.

Hüther W. 1968. Erstnachweis der Pauropoda Hexamerocerata für Südamerika, mit Beschreibung einer neuen Art. Rev. Écol. Biol. Sol 5: 561-567.

Hwang UW, Friedrich M, Tautz D, Park CJ, Kim W. 2001. Mitochondrial protein phylogeny joins myriapods and chelicerates. Nature 413: 154-157.

Ikeda Y, Machida R. 1998. Embryogenesis of the dipluran Lepidocampa weberi Oudemans (Hexapoda, Diplura, Campodeidae): external morphology. J. Morphol. 237: 101115.

Ikuta K, Makioka T. 1999. Evolution of ovarian structure and oogenesis in maxillopodan crustaceans. In: Schram FR, Vaupel Klein JC von, eds. Crustaceans and the Biodiversity Crisis. Proceedings of the Fourth International Crustacean Congress. Leiden: Brill, 91-100.

Imms AD. 1939. On the antennal musculature in insects and other arthropods. Quart. J. Micros. Sci. 81: 273-320.

Jamieson BGM. 1986. The spermatozoa of the Chilopoda (Uniramia): an ultrastructural review with data on dimorphism in Ethmostigmus rubripes and phylogenetic discussion. J. Submicros. Cytol. 18: 543-558.

Jamieson BGM. 1987. The Ultrastructure and Phylogeny of Insect Spermatozoa. Cambridge: Cambridge Univ. Press.

Jamieson BGM. 1991. Ultrastructure and phylogeny of crustacean spermatozoa. Mem. Qld. Mus. 31: 109-142.

Jamieson BGM, Dallai R, Afzelius BA. 1999. Insects, Their Spermatozoa and Phylogeny. New Delhi: Oxford Publishing.

Juberthie C, Bonaric JC. 1990. Ecdysial glands and ecdysteroids in terrestrial Chelicerata. In: Gupta AP, ed. Morphogenetic Hormones of Arthropods. Volume I. 2. Embryonic and Postembryonic Sources. New Brunswick, London: Rutgers Univ. Press, 269-305.

Kaufman ZS. 1967. The phylogenetic relationships of the Chilopoda to other groups of the Atelocerata. Rev. Entomol. USSR 48: 12-20.

Klass K-D. 1998. Possible homologies in the proventriculi of Dicondylia (Hexapoda) and Malacostraca (Crustacea). Zool. Anz. 237: 43-58.

Klass K-D, Kristensen NP. 2001. The ground plan and affinities of hexapods: recent progress and open problems. In:
Deuve T, ed. Origin of the Hexapoda. Ann. Soc. Entomol. France (N. S.) 37: 265-298.

Kluge NJ. 1999. Mitos en Sistemática y principios de Nomeclatura Zoológica. In: Melic A, de Haro JJ, Mendez M, Ribera I, eds. Evolución y Filogenia de Arthropoda. Bol. Soc. Entomol. Aragon. 26: 347-377.

Koch M. 1997. Monophyly and phylogenetic position of the Diplura (Hexapoda). Pedobiologia 41: 9-12.

Koch M. 2000. The cuticular cephalic endoskeleton of primarily wingless hexapods: ancestral state and evolutionary changes. Pedobiologia 44: 374-385.

Koch M. 2001. Mandibular mechanisms and the evolution of hexapods. In: Deuve T, ed. Origin of the Hexapoda. Ann. Soc. Entomol. France (N. S.) 37: 129-174.

Koch M. 2003. Monophyly of the Myriapoda? Reliability of current arguments. Proceedings of the $12^{\text {th }}$ International Congress of Myriapodology. Afr. Inverts. 44: 137-153.

Kraus O. 1974. On the morphology of Palaeozoic diplopods. In: Blower JG, ed. Myriapoda. Symp. Zool. Soc. Lond. 32: 13-22.

Kraus O. 1998. Phylogenetic relationships between higher taxa of tracheate arthropods. In: Fortey RA, Thomas RH, eds. Arthropod Relationships. London: Chapman and Hall, 295303:

Kraus 0.2001. "Myriapoda" and the ancestry of the Hexapoda. In: Deuve T, ed. Origin of the Hexapoda. Ann. Soc. Entomol. France (N. S.) 37: 105-127.

Kraus O, Brauckmann C. 2003. Fossil giants and surviving dwarfs. Arthropleurida and Pselophognatha (Atelocerata, Diplopoda): characters, phylogenetic relationships and construction. Verh. naturwiss. Ver. Hamburg 40: 5-50.

Kraus O, Kraus M. 1994. On "Myriapoda"-Insecta interrelationships, phylogenetic age and primary ecological niches (Arthropoda, Tracheata). Verh. naturwiss. Ver. Hamburg 34: 5-31.

Kraus O, Kraus M. 1996. On myriapod / insect interrelationships. In: Geoffroy J-J, Mauriès J-P, Nguyen Duy-Jacquemin M, eds. Acta Myriapodologica. Mém. Mus. natn. Hist. nat. 169: 283-290.

Kristensen NP. 1981. Phylogeny of insect orders. Ann. Rev. Entomol. 26: 135-157.

Kristensen NP. 1991. Phylogeny of extant hexapods. In: CSIRO, ed. The Insects of Australia. Melbourne: Melbourne Univ. Press, 125-140.

Kristensen NP. 1998. The groundplan and basal diversification of the hexapods. In: Fortey RA, Thomas RH, eds. Arthropod Relationships. London: Chapman and Hall, 281-293.

Kukalová-Peck J. 1991. Fossil history and the evolution of hexapod structures. In: CSIRO, ed. The Insects of Australia. Melbourne: Melbourne Univ. Press, 141-179.

Kukalová-Peck J. 1998. Arthropod phylogeny and 'basal' morphological structures. In: Fortey RA, Thomas RH, eds. $\mathrm{Ar}$ thropod Relationships. London: Chapman and Hall, 249-268.

Kunze JC. 1983. Stomatopoda and the evolution of the Hoplocarida. In: Schram FR. ed., Crustacean Phylogeny. Crustacean Issues, 1. Rotterdam: A. A. Balkema, 165-188. 
Kusche K, Burmester T. 2001. Diplopod hemocyanin sequences and the phylogenetic position of the Myriapoda. Mol. Biol. Evol. 18: 1566-1573.

Kusche K, Ruhberg H, Burmester T. 2002. A hemocyanin from the Onychophora and the emergence of respiratory pigments. Proc. Natl. Acad. Sci. USA 99: 10545-10548.

Larink O. 1997. Apomorphic and plesiomorphic characteristics in Archaeognatha, Monura, and Zygentoma. Pedobiologia 41: 3-8.

Lauterbach K-E. 1972. Uber die sogenannte GanzbeinMandibel der Tracheata, insbesondere der Myriapoda. Zool. Anz. 188: 145-154.

Lauterbach K-E. 1983. Zum Problem der Monophylie der Crustacea. Verh. naturwiss. Ver. Hamburg 26: 293-320.

Lavrov DV, Boore JL, Brown WM. 2002. Complete mtDNA sequences of two millipedes suggest a new model for mitochondrial gene rearrangements: Duplication and nonrandom loss. Mol. Biol. Evol. 19: 163-169

Legendre R. 1985. The stomogastric nervous system and neurosecretion. In: Barth FG, ed. Neurobiology of Arachnids. Berlin: Springer-Verlag, 38-49.

Locke M, Huie P. 1977. Bismuth staining of Golgi complex is a characteristic arthropod feature lacking in Peripatus. $\mathrm{Na}$ ture 270: 341-343.

Loesel R, Nässel DR, Strausfeld NJ. 2002. Common design in a unique midline neuropile in the brains of arthropods. $A r-$ thropod Struct. Dev. 31: 77-91.

Machida R. 2000. Serial homology of the mandible and maxilla in the jumping bristletail Pedetontus unimaculatus Machida, based on external embryology (Hexapoda, Archaeognatha, Machilidae). J. Morphol. 245: 19-28.

Machida R, Ando H. 1998. Evolutionary changes in developmental potentials of the embryo proper and embryonic membranes along with the derivative structures in Atelocerata, with special reference to Hexapoda (Arthropoda). Proc. Arthropod Embryol. Jpn. 33: 1-13.

Makioka T. 1988. Ovarian structure and oogenesis in chelicerates and other arthropods. Proc. Arthropod. Embryol. Soc. Jpn. 23: 1-11.

Manton SM. 1964. Mandibular mechanisms and the evolution of arthropods. Phil. Trans. R. Soc. Lond., B 247: 1-183.

Manton SM. 1965. The evolution of arthropodan locomotory mechanisms, Part 8. Functional requirements and body def sign in the Chilopoda, together with a comparative account of their skeleto-muscular systems and an Appendix on a comparison between burrowing forces of annelids and chilopods and its bearing upon the evolution of the arthropodan haemocoel. J. Linn. Soc. Lond. (Zool.) 45: 251483.

Manton SM. 1972. The evolution of arthropodan locomotory mechanisms, Part 10. Locomotory habits, morphology and evolution of the hexapod classes. Zool. J. Linn. Soc. 51: 203-400.

Manton SM. 1979. Functional morphology and the evolution of the hexapod classes. In: 'Gupta AP, ed. Arthropod Phylogeny. New York: Van Nostrand Reinhold, 387-465.

Martin JW. 1992. Branchiopoda. In: Harrison FW, Humes AG, eds. Microscopical Anatomy of Invertebrates, Volume 9. Crustacea. New York: Wiley-Liss, 25-224.
Martin JW, Laverack MS 1992. On the distribution of the crustacean dorsal organ. Acta Zool. 73: 357-368.

Mazzini M, Carcupino M, Fausto AM, Puri C, Zapparoli M. 1992. Further observations on the ultrastructure of mature sperm of Scutigera coleoptrata (L.) (Chilopoda-Scutigeromorpha). J. Sumicrosc. Cytol. Pathol. 24: 251-256.

Melzer RR, Diersch R, Nicastro D, Smola U. 1997. Compound eye evolution: highly conserved retinula and cone cell patterns indicate a common origin of the insect and crustacean ommatidium. Naturwiss. 84: 542-544.

Mikulic DG, Briggs DEG, Klussendorf J. 1985. A new exceptionally preserved biota from the Lower Silurian of Wisconsin, USA. Phil. Trans. R. Soc. B 311: 75-85.

Minelli A, Foddai D, Pereira LA, Lewis JGE. 2000. The evolution of segmentation of centipede trunk and appendages. J. Zool. Syst. Evol. Research 38: 103-117.

Minet J, Bourgoin T. 1986. Phylogenie et classification de Hexapodes (Arthropoda). Cah. Liason 63: 23-28.

Mittmann B, Scholtz G. 2003. Development of the nervous system in the "head" of Limulus polyphemus (Chelicerata: Xiphosura): morphological evidence for a correspondence between the segments of the chelicerae and of the (first) antennae of Mandibulata. Dev. Genes Evol. 213: 9-17.

Miyazaki K. 2002. On the shape of the forgeut lumen in sea spiders (Arthropoda: Pycnogonida). J. Mar. Biol. Ass. U.K. 82: 1037-1038.

Monge-Nájera J. 1995. Phylogeny, biogeography and reproductive trends in the Onychophora. Zool. J. Linn. Soc. 114: 21-60.

Mundel P. 1979. The centipedes (Chilopoda) of the Mazon Creek. In: Nitecki, MH, ed. Mazon Creek Fossils. New York: Academic Press, 361-378.

Nielsen C. 1995. Animal Evolution. Interrelationships of the Living Phyla. Oxford: Oxford Univ. Press.

Nielsen C. 1998. The phylogenetic position of the Arthropoda. In: Fortey RA, Thomas RH, eds. Arthropod Relationships. London: Chapman \& Hall, 11-22.

Nilsson D-E. 1989. Optics and evolution of the compound eye. In: Stavenga DG, Hardie RC, eds. Facets of Vision. Berlin: Springer-Verlag, 30-73.

Niwa N, Saitoh M, Ohuchi H, Yoshioka H, Noji S. 1997. Correlations between Distal-less expression patterns and structures of appendages in development of the two-spotted cricket, Gryllus bimaculatus. Zool. Sci. 14: 115-125.

O'Leary M. A. 1999. Parsimony analysis of total evidence from extinct and extant taxa and the cetacean-artiodactyl question (Mammalia, Ungulata). Cladistics 15: 315-330.

Osorio D, Averof M, Bacon JP. 1995. Arthropod evolution: great brains, beautiful bodies. Trends Ecol. Evol. 10: 449454.

Panganiban G, Sebring A, Nagy L, Carroll S. 1995. The development of crustacean limbs and the evolution of arthropods. Science 270: 1363-1366.

Pass G. 1991. Antennal circulatory organs in Onychophora, Myriapoda and Hexapoda: Functional morphology and evolutionary implications. Zoomorphol. 110: 145-164.

Pass G. 2000. Accessory pulsatile organs: evolutionary innovations in insects. Ann. Rev. Entomol. 45: 495-518.

Patterson C, Rosen DE. 1977. Review of ichthyodectiform and 
other Mesozoic teleost fishes and the theory and practice of classifying fossils. Bull. Amer. Mus. Nat. Hist. 158: 81172 ,

Paulus HF. 1979. Eye structure and the monophyly of the Arthropoda. In: Gupta AP, ed. Arthropod Phylogeny. New York: Van Nostrand Reinhold, 299-383.

Paulus HF. 1986. Evolutionswege zum Larvalauge der Insekten - ein Modell für die Entstehung und die Ableitung der ozellären Lateralaugen der Myriapoda von Fazettenaugen. Zool. Jb. Syst. 113: 353-371.

Paulus HF. 1989. Das Homologisieren in der Feinstrukturforschung: Das Bolwig-Organ der höheren Dipteren und seine Homologisierung mit Stemmata und Ommatidien eines ursprünglichen Fazettenauges der Mandibulata. Zool. Beiträge (N.F.) 32: 437-478.

Paulus HF. 2000. Phylogeny of the Myriapoda - Crustacea Insecta: a new attempt using photoreceptor structure. J. Zool. Syst. Evol. Research 38: 189-208.

Peterson M, Rogers BT, Popadic A, Kaufman TC. 1999. The embryonic expression pattern of labial, posterior homeotic complex gene and the teashirt homologue in an apterygote insect. Dev. Genes Evol. 209: 77-90.

Popadić A, Panganiban G, Rusch D, Shear WA, Kaufman TC. 1998. Molecular evidence for the gnathobasic derivation of arthropod mandibles and for the appendicular origin of the labrum and other structures. Dev. Genes Evol. 208: 142-150.

Popadić A, Rusch D, Peterson M, Rogers BT, Kaufman TC. 1996. Origin of the arthropod mandible. Nature 380: 395.

Prpic N-M, Wigand B, Damen WGM, Klinger M 2001. Expression of dachshund in wild-type and Distal-less mutant Tribolium corroborates serial homologies in insect appendages. Dev. Genes Evol. 211: 467-477.

Prunescu CC. 1996. Plesiomorphic and apomorphic character states in the Class Chilopoda. In: Geoffroy J-J, Mauriès J-P, Nguyen Duy-Jacquemin M, eds. Acta Myriapodologica. Mém. Mus. natn. Hist. nat. 169: 299-306.

Prunescu CC. 1997. The anatomy and evolution of the genital system in Scolopendromorpha (Chilopoda). Ent. Scand. Suppl. 51: 41-47.

Ravoux P. 1975. Endosquellete et musculature céphaliques de Scutigerella immaculata Newport (Symphyla: Scutigerellidae). Bull. Mus. natl. Hist. nat. 332: 1189-1238.

Regier JC, Shultz JW. 1997. Molecular phylogeny of the major arthropod groups indicates polyphyly of crustaceans and a new hypothesis for the origin of hexapods. Mol. Biol. Evol. 14: 902-913.

Regier JC, Shultz JW. 2001a. A phylogenetic analysis of Myriapoda (Arthropoda) using two nuclear protein-encoding genes. Zool. J. Linn. Soc. 132: 469-486.

Kegier JC, Shultz JW. 2001b. Elongation Factor-2: a useful gene for arthropod phylogenetics. Mol. Phylog. Evol. 20: 136-148.

Reissland A, Görner P. 1985. Trichobothria. In: Barth FG, ed. Neurobiology of Arachnids. Berlin: Springer-Verlag, 138161.

Retallack GJ. 2000. Ordovician life on land and Early Paleozoic global change. In: Gastaldo RA, Dimichele WA, eds. Phanerozoic Terrestrial Ecosystems. Paleontol. Soc. Papers 6: 21-45.

Retallack GJ. 2001. Scoyenia burrows from Ordovician palaeosols of the Juniata Formation in Pennsylvania. Palaeontol. 44: 209-235.

Richter S. 1999. The structure of the ommatidia of the Malacostraca (Crustacea) - a phylogenetic approach. Verh. naturwiss. Ver. Hamburg (NF) 38: 161-204.

Richter S. 2002a. The Tetraconata concept: hexapod-crustacean relationships and the phylogeny of Crustacea. Org. Divers. Evol. 2: 217-237.

Richter S. 2002b. Evolution of optical design in the Malacostraca. In: Wiese K, ed. The Crustacean Nervous System. Berlin: Springer-Verlag, 512-524.

Richter S, Edgecombe GD, Wilson GDF. 2002. The lacinia mobilis and similar structures - a valuable character in arthropod phylogenetics? Zool. Anz. 241 : 339-361.

Richter S, Scholtz G. 2001. Phylogenetic analysis of the Malacostraca. J. Zool. Syst. Evol. Research 39: 113-136.

Rilling G. 1968. Lithobius forficatus. Grosses Zoologisches Praktikum 13b. Stuttgart: Gustav Fischer.

Robison RA. 1990. Earliest known uniramous arthropod. $\mathrm{Na}$ ture 343: 163-164.

Robison RA, Wiley EO. 1995. A new arthropod, Meristosoma: more fallout from the Cambrian explosion. J. Paleontol. 69: 447-459.

Rosenberg J. 1979. Topographie und Feinstruktur des Maxillarnephridium von Scutigera coleoptrata (L.) (Chilopoda, Notostigmophora). Zoomorphol. 92: 141-159.

Rosenberg J. 1983. Coxal organs in Scolopendromorpha (Chilopoda): Topography, organization, fine structure and signification in centipedes. Zool. Jb., Anat. 110: 383-393.

Sanders HL. 1963. Significance of the Cephalocarida. In: Whittington HB, Rolfe WDI, eds. Phylogeny and Evolution of Crustacea. Cambridge: Mus. Comp. Zool., Spec. Publ., 163-175.

Scheller, U. 1982. Symphyla. In: Parker SP, ed. Synopsis and Classification of Living Organisms. New York: McGraw Hill, 688-689.

Schmidt-Rhaesa A, Bartolomaeus T, Lemburg C, Ehlers U, Garey JR. 1998. The position of the Arthropoda in the phylogenetic system. J. Morphol. 238: 263-285.

Scholtz G. 1998. Cleavage, germ band formation and head segmentation: the ground pattern of the Euarthropoda. In: Fortey RA, Thomas RH, eds. Arthropod Relationships. London: Chapman and Hall, 317-332.

Scholtz G. 2000. Evolution of the nauplius stage in malacostracan crustaceans. J. Zool. Syst. Evol. Research 38: 175187.

Scholtz G. 2001. Evolution of developmental patterns in arthropods - the analysis of gene expression and its bearing on morphology and phylogenetics. Zool. 103: 99-111.

Scholtz G. 2002. The Articulata hypothesis - or what is a segment? Org. Divers. Evol. 2: 197-215.

Scholtz G, Mittmann B, Gerberding M. 1998. The pattern of Distal-less expression in the mouthparts of crustaceans, 
myriapods and insects: new evidence for a gnathobasic mandible and the common origin of Mandibulata. Int. J. Dev. Biol. 42: 801-810.

Schram FR. 1986. Crustacea. Oxford: Oxford Univ. Press.

Schram FR, Hof CHJ. 1998. Fossils and the interrelationships of major crustacean groups. In: Edgecombe GD, ed. $A r$ thropod Fossils and Phylogeny. New York: Columbia, 233302.

Schram FR, Koenemann S. 2001. Developmental genetics and arthropod evolution: part I, on legs. Evol. Dev. 3: 343-354.

Schürmann FW. 1995. Common and special features of the nervous system of Onychophora: a comparison with Arthropoda, Annelida and some other invertebrates. In: Breidbach $\mathrm{O}$, Kutsch W, eds. The Nervous System of Invertebrates. An Evolutionary and Comparative Approach. Basel: Birkhäuser Verlag, 139-158.

Seifert G. 1990. Morphology, histology, and ultrastructure of the ecdysial glands in Myriapoda. In: Gupta AP, ed. Morphogenetic Hormones of Arthropods. Volume I. 2. Embryonic and Postembryonic Sources. New Brunswick, London: Rutgers Univ. Press, 307-341.

Selden PA, Shear WA, Bonamo PM. 1991. A spider and other arachnids from the Devonian of New York, and reinterpretations of Devonian Araneae. Palaeontol. 34: 241-281.

Sharov AG. 1966. Basic Arthropodan Stock. New York: Pergamon Press.

Shear WA. 1994. Myriapodous arthropods from the Viséan of East Kirkton, West Lothian, Scotland. Trans. R. Soc. Edinburgh: Earth Sci. 84: 309-316.

Shear WA. 1998. The fossil record and evolution of the Myriapoda. In: Fortey RA, Thomas RH, eds. Arthropod Relationships. London: Chapman and Hall, 211-219.

Shear WA, Bonamo PM. 1988. Devonobiomorpha, a new order of centipeds (Chilopoda) from the Middle Devonian of Gilboa, New York State, USA, and the phylogeny of centiped orders. Amer: Mus. Novitates 2927: 1-30.

Shear WA, Gensel PG, Jeram AJ. 1996. Fossils of large terrestrial arthropods from the Lower Devonian of Canada. Nature 384: 555-557.

Shear WA, Jeram AJ, Selden PA. 1998. Centiped legs (Arthropoda, Chilopoda, Scutigeromorpha) from the Silurian and Devonian of Britain and the Devonian of North America. Amek. Mus. Novitates 3231: 1-16.

Shear WA, Selden PA. 1995. Eoarthropleura (Arthropoda, Arthropleurida) from the Silurian of Britain and the Devonian of North America. N. Jb. Geol. Paläontol. Abh. 196: 347-375.

Shear WA, Selden PA, Rolfe WDI, Bonamo PM, Grierson JD. 1987. New terrestrial arachnids from the Devonian of Gilboa, New York (Arachnida, Trigonotarbida). Amer. Mus. Novitates 2901: 1-74.

Shinohara K. 1970. On the phylogeny of Chilopoda. Proc. Jap. Soc. Syst. Zool. 65: 35-42.

Shultz JW. 1989. Morphology of locomotory appendages in Arachnida: evolutionary trends and phylogenetic implications. Zool. J. Linn. Soc. 97: 1-56.

Shultz JW. 1990. Evolutionary morphology and phylogeny of the Arachnida. Cladistics 6: 1-38.

Shultz JW. 2000. Skeletomuscular anatomy of the harvestman
Leiobunum aldrichi (Weed, 1893) (Arachnida: Opiliones: Palpatores) and its evolutionary significance. Zool. J. Linn. Soc. 128: 401-438.

Shultz JW. 2001. Gross muscular anatomy of Limulus polyphemus (Xiphosura, Chelicerata) and its bearing on evolution in the Arachnida. J. Arachnol. 29: 283-303.

Shultz JW, Regier JC. 2001. Phylogenetic analysis of arthropods using two nuclear protein-encoding genes supports a crustacean + hexapod clade. Proc. R. Soc. Lond. B 267: 1011-1019.

Siewing R. 1963. Studies in malacostracan morphology. In: Whittington HB, Rolfe WDI, eds. Phylogeny and Evolution of Crustacea. Cambridge: Mus. Comp. Zool., Spec. Publ., 85-110.

Simpson P. 2001. A review of early development of the nervous system in some arthropods: comparison between insects, crustaceans and myriapods. In: Deuve T, ed. Origin of the Hexapoda. Ann. Soc. Entomol. France (N. S.) 37: 71-84.

Snodgrass RE. 1938. Evolution of the Annelida, Onychophora, and Arthropoda. Smithsonian Misc. Coll. 97: 1-159.

Snodgrass RE. 1950. Comparative studies on the jaws of mandibulate arthropods. Smithsonian Misc. Coll. 116: 185.

Snodgrass RE. 1952. A Textbook of Arthropod Anatomy. Ithaca Cornell Univ. Press.

Spies T. 1981. Structure and phylogenetic interpretation of diplopod eyes (Diplopoda). Zoomorphol. 98: 241-260.

Staniczek AH. 2000. The mandible of silverfish (Insecta: Zygentoma) and mayflies (Ephemeroptera): its morphology and phylogenetic significance. Zool. Anz. 239: 147-178.

Storch V, Ruhberg H. 1993. Onychophora. In: Harrison FW, Rice ME, eds. Microscopic Anatomy of Invertebrates, Volume 12. Onychophora, Chilopoda, and Lesser Protostomata. New York: Wiley-Liss, 11-56.

Stormer L. 1976. Arthropods from the Lower Devonian (Lower Emsian) of Alken-an-der-Mosel, Germany. Part 5: Myriapoda and additional forms, with general remarks on fauna and problems regarding invasion of land by arthropods. Senckenbergiana lethaea 57: 87-183.

Strausfeld NJ. 1998. Crustacean - insect relationships: the use of brain characters to derive phylogeny amongst segmented invertebrates. Brain Behav. Evol. 52: 186-206.

Strausfeld NJ, Buschbeck EK, Gomez RS. 1995. The arthropod mushroom body: its functional roles, evolutionary enigmas and mistaken identities. In: Briedbach O, Kutsch W, eds. The Nervous System of Invertebrates. An Evolutionary and Comparative Approach. Basel: Birkhäuser, 349-381.

Sturm H. 1997. The mating behaviour of Tricholepidion gertschi Wygod., 1961 (Lepidotrichidae, Zygentoma) and its comparison with the behaviour of other "Apterygota". Pedobiologia 41: 44-49.

Stys P, Bilinski S. 1990. Ovariole types and the phylogeny of hexapods. Biol. Rev. 65: 401-429.

Stys P, Zrzavý J, Weyda F. 1993. Phylogeny of the Hexapoda and ovarian metamerism. Biol. Rev. 68: 365-379.

Swofford DL. 2002. PAUP*: Phylogenetic Analysis Using Parsimony (*and Other Methods). Sunderland, MA: Sinauer.

Telford MJ, Thomas RH. 1998. Expression of homeobox genes 
shows chelicerate arthropods retain their deutocerebral segment. Proc. Natl. Acad. Sci. USA 95: 10671-10675.

Tesakov AS, Alekseev AS. 1992. Myriapod-like arthropods from the Lower Devonian of central Kazakhstan. Paleontol. $J$. 26: $18-23$.

Tiegs OW. 1947. The development and affinities of the Pauropoda, based on a study of Pauropus sylvaticus. Q.J. Microsc. Sci. 88: 165-336.

Verhoeff KW. 1902-25. Chilopoda. In: Bronn HG, ed. Klassen und Ordnungen des Tierreichs, 5, Abt. 2, Buch 1. Leipzig: Akad. Verlagsges, 1-725.

Wägele J-W. 1993. Rejection of the "Uniramia" hypothesis and implications of the Mandibulata concept. Zool. Jb., Syst. 120: 253-288.

Wägele J-W, Stanjek G. 1995. Arthropod phylogeny inferred from partial 12SrRNA revisited: monophyly of the Tracheata depends on sequence alignment. J. Zool. Syst. Evol. Research 33: $75-80$.

Walossek D. 1993. The Upper Cambrian Rehbachiella and the phylogeny of Branchiopoda and Crustacea. Fossils and Strata 32: 1-202.

Walossek D. 1995. The Upper Cambrian Rehbachiella, its larval development, morphology, and significance for the phylogeny of Branchiopoda and Crustacea. Hydrobiologia 31: $1-13$.

Walossek D. 1999. On the Cambrian diversity of Crustacea. In: Schram FR, Vaupel Klein JC von, eds. Crustaceans and the Biodiversity Crisis. Proceedings of the Fourth International Crustacean Congress. Leiden: Brill, 3-27.

Waloszek D, Dunlop JA. 2002. A larval sea spider (Arthropoda: Pycnogonida) from the Upper Cambrian 'Orsten' of Sweden, and the phylogenetic position of pycnogonids. Palaeontol. 45: 421-446.

Walossek D, Müller KJ. 1990. Upper Cambrian stem-lineage crustaceans and their bearing upon the monophyletic origin of Crustacea and the position of Agnostus. Lethaia 23: 409427.

Walossek D, Müller KJ. 1992. The 'alum shale window' - contribution of 'Orsten' arthropods to the phylogeny of Crustacea. Acta Zool. 73: 305-312.

Walossek D, Müller KJ. 1998a. Cambrian 'Orsten'-type arthropods and the phylogeny of Crustacea. In: Fortey RA, Thomas RH, eds. Arthropod Relationships. London: Chapman and Hall, 139-153.

Walossek D, Müller KJ. 1998b. Early arthropod phylogeny in light of the Cambrian "Orsten" fossils. In: Edgecombe GD, ed. Arthropod Fossils and Phylogeny. New York: Columbia Univ. Press, 185-231.

Wegerhoff R, Breidbach O. 1995. Comparative aspects of the chelicerate nervous system. In: Breidbach O, Kutsch W, eds. The Nervous System of Invertebrates. An Evolutionary and Comparative Approach. Basel: Birkhäuser Verlag, 159-179.

Weygoldt P. 1979. Significance of later embryonic stages and head development in arthropod phylogeny. In: Gupta AP, ed. Arthropod Phylogeny. New York: Van Nostrand Reinhold, 107-135.

Weygoldt P. 1985. Ontogeny of the arachnid central nervous system. In: Barth FG, ed. Neurobiology of Arachnids. Berlin: Springer-Verlag, 20-37.
Weygoldt P. 1986. Arthropod interelationships - the phylogenetic-systematic approach. Z. Zool. Syst. Evol.-forsch. 24: 19-35.

Weygoldt P, Paulus HP. 1979. Untersuchung zur Morphologie, Taxonomie und Phylogenie der Chelicerata. II. Cladogramme und die Entfaltung der Chelicerata. Z. Zool. Syst. Evol.-forsch. 17: 177-200.

Williams TA. 1999. Morphogenesis and homology in arthropod limbs. Amer. Zool. 39: 664-675.

Wilson HM. 2003. A new scolopendromorph centipede (Myriapoda: Chilopoda) from the Lower Cretaceous (Aptian) of Brazil. J. Paleontol. 77: 73-77.

Wilson, HM, Anderson, LI. 2004. Morphology and taxonomy of Paleozoic millipedes (Diplopoda: Chilognatha: Archipolypoda) from Scotland. J. Paleontol. 77: 169-184.

Wilson HM, Shear WA. 2000. Microdecemplicida, a new order of minute arthropleurideans (Arthropoda: Myriapoda) from the Devonian of New York State, U.S.A. Trans. R. Soc. Edinburgh: Earth Sci. 90: 351-375.

Winter G. 1980. Beiträge zur Morphologie und Embryologie des vorderen Körperabschnittes (Cephalosoma) der Pantopoda Gerstaecker, 1963. I. Entstehung und Struktur des.Zentralnervensystems. Z. Zool. Syst. Evol.-forsch. 18: 27-61

Wirkner CS, Pass G. 2002. The circulatory system in Chilopoda: functional morphology and phylogenetic aspects. Acta Zool. 83: 193-202.

Yahata K, Makioka T. 1994. Phylogenetic implications of structure of adult ovary and oogenesis in the penicillate diplopod, Eudigraphus nigricians (Miyosi) (Diplopoda: Myriapoda). J. Morphol. 222: 223-230.

Zrzavý J, Stys P. 1995. Evolution of metamerism in Arthropoda: developmental and morphological perspectives. $Q$ Rev. Biol. 70: 279-295.

Received: 12 November 2002

\section{Appendix 1. Characters used in phylogenetic analysis}

For characters described by Edgecombe et al. (2000), a citation E\# indicates the relevant character number in that study. Descriptions of additional characters used by Giribet et al. (2001) are available electronically as Supplementary Information from www.nature.com., and

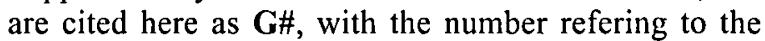
character number in that study.

1. Non-migratory gastrulation: (0) absent; (1) present [E1] (Anderson, 1973).

2 . Early cleavage: $(0)$ total cleavage with radially oriented position of cleavage products; (1) intralecithal cleavage [E3; G2] (Scholtz, 1998).

3. Blastokinesis with amnioserosal fold: $(0)$ absent; (1) amniotic cavity open; (2) amniotic cavity closed, 
amnioserosal fold fuses beneath the embryo [E5; G3] (Machida and Ando, 1998). ORDERED

4. Blastoderm cuticle (cuticular egg envelope): (0) absent; (1) present [E6; G4] (Anderson, 1973; Machida and Ando, 1998).

5. Dorsal closure of embryo: (0) definitive dorsal closure (dorsal covering of embryo participates in the definitive dorsal closure); (1) provisional dorsal closure (embryonic dorsal covering degenerates without participating in the definitve closure, which is exclusively derived from the embryo) [G5] (Machida and Ando, 1998).

6. Ectoteloblasts forming part of metanaupliar/eggnaupliar region of germ band: (0) absent; (1) present, at anterior border of blastopore [E7; G6] (Gerberding, 1997).

7. Caudal papilla: (0) absent; (1) present, anteroventrally folded, derived from preanal growth zone [G7] (Scholtz, 2000).

8. Fat Body: (0) absent; (1) fat body cells develop from vitellophages in yolk; (2) fat body cells develop from walls of mesodermal somites [E9] (Anderson, 1973).

9. Midgut developed within the yolk: (0) midgut cells enclose the yolk; (1) lumen of embryonic midgut lacking yolk globules (Tiegs, 1947; Dohle 1980).

10. Fate map ordering of embryonic tissues: (0) presumptive mesoderm posterior to presumptive midgut; (1) presumptive mesoderm anterior to midgut; (2) mesoderm midventral, cells sink and proliferate, midgut internalises during cleavage; (3) mesoderm diffuse through the ectoderm; (4) midgut develops from anterior and posterior rudiments at each end of midventral mesoderm band $[$ E10; G9] (Anderson, 1973, 1979).

11. Embryological development: (0) with a growth zone giving rise to both the prosoma and opisthosoma; (1) with a growth zone giving rise to the opisthosoma [G10] (Anderson, 1973; Dunlop and Webster, 1999).

12. Engrailed expressed in mesoderm patterning: (0) present; (1) absent [E2; G11] (Zrzavý and Štys) 1995; Dohle, 1998).

13. Epimorphic development: (0) absent; (1) present [E11].

14. Nauplius larva or egg-nauplius: (0) absent; (1) present [E12; G13] (Dahms, 2000; Scholtz, 2000).

15. Pupoid stage (motionless stage after hatching, pupoid remains encased in embryonic cuticle): (0) absent; (1) present [E13] (Anderson, 1973; Dohle, 1980).

16. Imaginal (post-adult) moult: (0) present; (1) absent (Kristensen 1991; Beutel and Gorb 2001).

17. Sclerotisation of cuticle into hard, articulated tergal exoskeleton: (0) absent; (1) present [E14].

18. Cuticle calcification: (0) absent; (1) present [G17] (Enghoff, 1984).

19. Cilia: (0) present in several organ systems (includ- ing nephridia, genital tract, and photoreceptors); (1) present in (at most) sperm. This refines the coding of Edgecombe et al. (2000: character 17), which coded the euarthropod state with reference to cilia being present only in sperm (versus also present in the photoreceptors in Onychophora, and in some other tissues, such as the nephridia, genital tracts and developing ventral organ of the anteriormost segment: Eriksson et al., 2003).

20. Tendon cells with tonofilaments penetrating epidermis: (0) absent; (1) present [E 18] (Boudreaux, 1979; Dewel and Dewel, 1998).

21. Dorsal longitudinal ecdysial suture with forking on head: (0) absent; (1) present [G20] (Kaufman, 1967; Boudreaux, 1979).

22. Transverse and antennocellar sutures on head shield: (0) absent; (1) present [G21] (Edgecombe et al., 1999].

23. Resilin protein: (0) absent; (1) present [E21] (Hackman, 1984).

24. Moulting gland: (0) absent; (1) present [E22] (Seifert, 1990; Wägele, 1993). Wägele (1993) noted that the moulting glands in insects and crustaceans are hypodermal derivations of the second maxilla, and are absent in chelicerates. The ultrastructure of the so-called moulting gland of spiders has, however, led some workers to consider these endocrine cells as homologous with the insect prothoracic gland (Juberthie and Bonaric, 1990).

25. Bismuth staining of Golgi complex beads: $(0)$ not staining; (1) staining [E23; G24] (Locke and Huie, 1977).

26. Metanephridia with sacculus with podocytes: $(0)$ absent; (1) present [E24] (Nielsen, 1998; SchmidtRhaesa et al., 1998).

27. Distribution of segmental glands: (0) on many segments; (1) on at most last four cephalic segments and first two post-cephalic segments; (2) on at most second antennal and/or maxillary segments [E25] (Lauterbach, 1983; Wägele, 1993). ORDERED

28. Maxillary nephridia: $(0)$ absent in postembryonic stadia; (1) paired; (2) fused nephridia of both maxillary segments. Edgecombe et al. (1999: character 31) employed states 0 and 2 for Chilopoda (describing Craterostigmus + Epimorpha s.str. and Scutigeromorpha + Lithobiomorpha, respectively), but an additional state is added to accommodate the paired maxillary nephridia in Symphyla, Pauropoda and Diplopoda. Dohle (1985) accordingly considered presence of maxillary nephridia to be symplesiomorphic for Chilopoda. Sampling for chilopods employs descriptions by Herbst (1891), Fahlander (1938), Manton (1965), Rilling (1968), Gabe (1972), and Rosenberg (1979). Coding for the homologue in Hexapoda, the labial kidneys (Gabe, 1972), follows Bitsch and Bitsch (1998: character 13). Codings for Crustacea are based on 
the paired maxillary glands (Martin, 1992 for branchiopods; Richter and Scholtz, 2001, character 58 for malacostracans).

29. Coxal gland orifice, leg I: (0) absent; (1) present [G301]. Gabe (1972) and Shultz (1990) indicated that the coxal glands of chelicerates are likely homologous with paired excretory organs of other arthropods and onychophorans (see characters 27, 28 ). Given the segmental correspondence of chelicerate leg I and the mandible of Mandibulata, an absence of mandibular nephridia permits coding of this character.

30. Tömösváry organ (protocerebral "temporal organs" at side of head behind insertion of antenna): (0) absent; (1) present [E26; G27] (Haupt, 1979). Similarities between Bellonci's organ in crustaceans and the temporal organs of myriapods and hexapods allow for a possibility of homology (Klass and Kristensen, 2001).

31. Salivary gland reservoir: (0) absent; (1) present [E27] (Monge-Nájera, 1995).

32. Malpighian tubules formed as endodermal extensions of the midgut: (0) absent, (1) [E28] (Shultz, 1990).

33. Malpighian tubules formed as ectodermal extensions of the hindgut: (0) absent; (1) single pair of Malpighian tubules at juncture of midgut and hindgut; (2) multiple pairs of tubules at anterior end of hindgut [E29] (Clarke, 1979; Bitsch and Bitsch, 1998).

34. Form of ectodermal Malpighian tubules: (0) elongate; (1) papillate [E30] (Bitsch and Bitsch, 1998).

35. Neck organ: (0) absent; (1) present [E31; G32] (Martin and Laverack, 1992; Walossek, 1993).

36. Hemoglobin: (0) absent; (1) present [G34] (Goodwin, 1960; Clarke, 1979).

37. Subcutaneous hemal channels in body wall: (0) absent; (1) present [E34] (Monge-Nájera, 1995).

38. Dorsal heart with segmental ostia and pericardial sinus: (0) absent; (1) present [E36; G36].

39 . Interval valves formed by lips of ostiae projecting deeply into the heart lumen to prevent haemolymph backflow within the heart: (0) absent; (1) present. Codings are restricted to Chilopoda, using data from Wirkner and Pass (2002).

40. Circumesophageal circulatory vessel ring with ventral, trumpet-shaped opening towards head: $(0)$ absent; (1) present [G37] (Gereben-Krenn and Pass, 1999; Wirkner and Pass, 2002).

41. Slit sensilla: (0) absent; (1) present [E38; G38] (Barth, 1985; Shultz, 1990).

42. Ganglion formation: ( 0 ) ganglia formed from an invagination of the ventral organ; (1) neuroblasts [E39; G39] (Duman-Scheel and Patel, 1999; Dohle, 2001).

43. Early differentiating neurons aCC, pCC, RP2, U/ CQ, EL and AUN: (0) absent; (1) present [G40] (Duman-Scheel and Patel, 1999).
44. EC neurons: (0) ECa and EPa only; (1) ECa, ECp and ECI. A series of Engrailed-postive neurons can be identified as homologues in malacostracans, collembolans and insects (Dumen-Scheel and Patel, 1999). Collembola and Insecta share more detailed similarity in having a third EC neuron (ECI) versus two in Malacostraca. As for character 43, Oniscidea is coded from Porcellio and Arthropleona from Folsomia (Dumen-Scheel and Patel, 1999).

45. Globuli cells: (0) confined mainly to brain, in massive clusters; (1) making up majority of neuropil and ventral layer of ventral nerve cord [E40] (Schürmann, 1995).

46. Corpora allata: (0) absent; (1) present [E41] (Cassagnau and Juberthie, 1983; Wägele, 1993).

47. Intrinsic secretory cells in protocerebral neurohemal organ: (0) absent; (1) present [E42] (Gupta, 1983).

48. Enlarged epipharyngeal ganglia: (0) absent; (1) present [E43] (François, 1969; Kristensen, 1991).

49. Innervation of mouth area by anterior stomogastric nervous system: (0) absent; (1) present. Tardigrades and euarthropods share innervation of the stomodeum, pharynx and integument near the mouth by the anterior stomogastric nervous system (Dewel et al., 1999), whereas oynchophorans lack this innervation in the mouth area (Eriksson and Budd, 2000). The corresponding structures in Onychophora are the muscular lips or oral papillae, which Eriksson and Budd (2000) suggested are epidermal derivatives rather than part of the stomogastric system. In arthropods, the anterior sympathetic ganglia in the mouth region function as endocrine organs similar to the neurosecretory cells of the CNS (Legendre, 1985).

50. Ganglia of pre-oesophageal brain: $(0)$ protocerebrum; (1) protocerebrum and deutocerebrum; (2) proto-, deuto- and tritocerebra [E44] (Dewel and Dewel, 1996; Walossek and Müller, 1998a).

51. Ganglia of post-oral appendages fused into single nerve mass: (0) absent; (1) present [E45] (Wegerhoff and Breidbach, 1995).

52. Fan-shaped body with neurons extending laterally into protocerebral lobes: (0) absent; (1) present [G47] (Strausfeld, 1998).

53. Midline neuropil 1: (0) absent; (1) present. Immunostaining permits midline neuropils to be identified in chilopods, crustaceans, hexapods and chelicerates (arcuate body: see character 55) but they are absent in Diplopoda (Loesel et al., 2002).

54. Midline neuropil 2: (0) absent; (1) present. The stratified midline neuropil of Chilopoda (Scolopendra spp.) shares immunoreactivity properties (allostatin-like immunoreactivity and tachykinin-related peptide) with the modular central complex of the brain in hexapods and crustaceans (Loesel et al., 2002).

55. Arcuate body in brain: (0) absent; (1) present [G48]. 
Strausfeld (1998) regarded the arcuate body, which has highly conserved structure (e.g., palisades of columnar neurons intersected by discrete layers of tangential processes), to be a chelicerate/pycnogonid synapomorphy. Loesel et al. (2002) allowed for a possible homology with the central body of other arthropods.

56. Ellipsoid body in brain: (0) absent; (1) present [G50] (Strausfeld, 1998).

57. Noduli in brain: (0) absent; (1) present [G51] (Strausfeld, 1998).

58. Protocerebral bridge, composed of small bushy dendrites that intersect axons between the two halves of the brain; dendrites supply complex pattern of axonal projections to the fan-shaped body: (0) absent; (1) present [G52] (Strausfeld, 1998).

59. Mushroom body calyces: (0) absent; (1) present (Strausfeld et al., 1995).

60. Cephalon composed of one pair of preoral appendages and (at least) three pairs of postoral appendages: (0) absent; (1) present [E47] (Walossek, 1993; Scholtz, 1998).

61. Cephalic kinesis (movable ophthalmic / antennular segments and articulated rostrum): (0) absent; (1) present [E48; G54] (Siewing, 1963; Kunze, 1983).

62. Flattened head capsule, with head bent posterior to the clypeus, accommodating antennae at anterior margin of head: (0) absent; (1) present [E49; G55] (Dohle, 1985).

63. Clypeofrontal sulcus (epistomal suture): (0) absent; (1) present [G56] (Bitsch and Bitsch, 2000).

64. Lateral eyes: (0) absent; (1) simple lens with cup-shaped retina; (2) stemmata with rhabdom of multilayered retinular cells; (3) facetted; (4) onychophoran eye [E52] (Paulus, 2000).

65. Compound eyes medial margins: (0) separate; (1) medially contiguous [E53] (Hennig, 1969).

66. Compound eye stalked, basally articulated: (0) absent (eye sessile); (1) present [G59].

67. Compound eyes internalised early in ontogeny, shifted dorsally into a cuticular pocket: $(0) \mathrm{ap}-$ sent; (1) present [G60] (Walossek, 1995).

68. Ophthalmic ridges: (0) absent; (1) present [G61] (Anderson and Selden, 1997).

69. Ommatidium with crystalline cone: $(0)$ absent; (1) present. See text discussion of ommatidia.

70. "Tetraconate" eye (two corneageneous cells, four Semper cells in crystalline cone, retinula with eight cells): (0) absent (variable, higher number of parts); (1) present [E55; G62] (Paulus, 2000).

71. Pigment cells in ommatidium: $(0)$ corneagenous cells not primary pigment cells; (1) two corneagenous cells are primary pigment cells [E51] (Paulus, 1979).

72. Crystalline cone cells: $(0)$ tetrapartite crystalline cone; (1) cone bipartitite, with two accessory cells; (2) five cone cells [G64] (Martin, 1992; Richter, 1999).
73. Reduction of processes of crystalline cone-producing cells: (0) all cells have processes that pass through clear zone and rhabdom; (1) only accessory cells have processes [G65] (Richter, 1999).

74. Distally displaced nuclei of accessory crystalline cone cells: (0) absent; (1) present [G66] (Richter, 1999).

75. Clear zone between dioptric apparatus and retina: (0) absent (apposition eye); (1) present (superposition eye). Codings for apposition and superposition eyes in Malacostraca follow Richter (2002b). Of terminals with a clear zone coded here, Anaspides (refracting superposition eye) differs in detail from Homarus and the presumed basal state for Reptantia (reflecting superposition eye). Branchiopods except for some Cladocera have simple apposition eyes, and apposition eyes are likewise present in basal insects (Nilsson, 1989; Richter, 2002b).

76. Optic neuropils: (0) no chiasmata; (1) one chiasma (between lamina ganglionaris and medulla); (2) two chiasmata (between lamina ganglionaris and medulla / between medulla and lobula) [E54; G67] (Osorio et al., 1995; Strausfeld, 1998). ORDERED

77. Lateral eye rhabdomes with quadratic network: $(0)$ absent; (1) present [G68] (Weygoldt and Paulus, 1979; Dunlop and Webster, 1999).

78. Number of median eyes: (0) none; (1) four; (2) three; (3) two; (4) one (embryonic) [E57] (Paulus, 1979).

79. Inverted median eye: (0) absent; (1) present [E58] (Paulus, 1979).

80. Median eyes fused to naupliar eyes: $(0)$ absent; (1) present [E56] (Lauterbach, 1983).

81. Type of sensory cells in naupliar eye: $(0)$ inverse; (1) everse [G72] (Elofsson, 1966; Paulus, 1979).

82. Tapetal cells in cups of naupliar eye: (0) absent; (1) present [G73] (Elofsson, 1966).

83. Dorsal frontal organs: (0) absent; (1) present [G74] (Elofsson, 1965, 1966).

84. Posterior medial frontal organ: (0) absent; (1) present [G75] (Elofsson, 1966).

85. Ocular tubercle: (0) absent; (1) present [G77] (Giribet et al., 2002).

86. Trichobothria innervated by several sensory cells, with dendrites having only indirect contact with the hair base: (0) absent; (1) present [G78] (Reissland and Görner, 1985).

87. Basal bulb in trichobothria: (0) absent; (1) present [E59] (Haupt, 1979).

88. Head/mouth orientation: $(0)$ head prognathous, mouth directed anteroventrally; (1) head hypognathous, mouth directed ventrally; (2) mouth directed posteriorly [G81] (Bitsch and Bitsch, 2000).

89. Labrum: (0) absent; (1) present [E64]. According to Eriksson and Budd (2000) the so-called labrum of Onychophora is pharyngeal and non-homologous with the euarthropod labrum, which devel- 
ops from a bilobed anlage (Scholtz, 1998).

90. Fleshy labrum with setulate sides and specialised glands: (0) absent; (1) present [E65] (Walossek and Müller, 1990).

91. Entognathy (overgrowth of mandibles and maxillae by cranial folds): (0) absent; (1) present [E66] (Kluge, 1999).

92. Admentum differentiated latero-ventrally on each side of head capsule, developed from posterior part of mouth fold: (0) absent; (1) present [G85] (Koch, 1997; Ikeda and Machida, 1998).

93. Sclerotic sternum formed by antennal to maxillulary sternites: (0) absent; (1) present [E67] (Walossek, 1999).

94. Tritosternum: (0) absent; (1) present [G87] (Shultz, 1990).

95. Clypeolabrum and labium mobility: (0) free; (1) immobile [E68] (Kukalová-Peck, 1991).

96. Hypopharynx: (0) absent or only a median lingua; (1) complete hypopharynx consisting of lingua and paired superlinguae [G89] (Bitsch and Bitsch, 2000).

97. Fulturae: (0) absent or limited to a hypopharyngeal suspensorium; (1) present, in groove between arthrodial membrane of maxilla and labium, connecting hypopharynx with posterior tentorial apodemes [G90] (Bitsch and Bitsch, 2000). So-called fulturae of myriapods are not positionally equivalent to the fulturae of hexapods, the details of which are added to the character definition (Koch, 2003).

98. Posterior process of tentorium fused anteriorly with hypopharyngeal bar and transverse bar: (0) absent; (1) present [G91] (Bitsch and Bitsch, 2002; Koch, 2003).

99. Triradiate pharyngeal lumen: (0) absent; (1) present [E69] (Schmidt-Rhaesa et al., 1998; Miyazaki, 2002).

100. Three-branched epistomal skeleton supporting the pharyngeal dilator muscles: (0) absent; (1) present [G93] (Shultz, 2000).

101. Stomothecae: (0) absent; (1) present [E70; G94] (Shultz, 2000).

102. Post-cephalic filter feeding apparatus with sternitic food groove: (0) absent; (1) present [E71] (Walossek, 1993).

103. Appendage of second (deutocerebral) head segment: (0) locomotory leg 1; (1) antenna; (2) chelicera/chelifore; (3) jaw. Segmental correspondence between leg 1 of Onychophora and Tardigrada and the antennal segment of arthropods was proposed by Dewel and Dewel (1996: table 1), whereas Eriksson et al. (2003), followed here, considered the jaw of Onychophora to be the segmental equivalent of the euarthropod antenna, with the first leg of onychophorans corresponding to the mandible (and homologues) of euarthropods. Winter (1980) defended primary homology of chelicerae and chelifores.
104. Antennal rami: (0) uniramous; (1) multiramous [E72; G96].

105. Antennal apical cone sensilla: (0) absent; (1) present [E74] (Enghoff, 1984).

106. Two lateral areas bearing club-like sensilla basiconica on terminal antennal article: (0) absent; (1) present (Foddai and Minelli, 2000).

107. Intrinsic muscles of antenna: (0) present; (1) absent (flagellum) [E75; G99] (Imms, 1939).

108. Scape and pedicel differentiated in antenna, with Johnson's organ: (0) absent; (1) present [G100] (Imms, 1939).

109. Antennal circulatory vessels: $(0)$ antennal vessels joined with dorsal vessel; (1) antennal and dorsal vessels separate; (2) antennal vessels absent [E77] (Pass, 1991).

110. Ampullo-ampullary dilator and ampullo-aortic dilator muscle: (0) absent; (1) present [G103] (Pass, 2000).

111. Statocyst in basal segment of first antenna: (0) absent; (1) present [G104] (Richter and Scholtz, 2001).

112. Cheliceral segmentation: (0) three segments, the last two forming a chela; (1) two segments, subchelate, "clasp-knife" type [G106] (Shear et al., 1987).

113. Plagula ventralis: (0) absent; (1) present [G107] (Shear et al., 1987).

114. Cheliceral tergo-deutomerite muscles: $(0)$ absent; (1) present [G108] (Shultz, 2000).

115. Appendage on third (tritocerebral) head segment: (0) unspecialised locomotory leg; (1) second antenna; (2) intercalary appendage absent; (3) pedipalp; (4) oral papilla with slime glands and adhesive glands [E78]. The presumed plesiomorphic state is that observed in fossil groups such as trilobites, in which this post-antennal limb is undifferentiated from other cephalic limbs (or, for that matter, from trunk limbs). This state is grouped with that in tardigrades (locomotory leg 2: Dewel and Dewel, 1996, table 2) as an undifferentiated locomotory leg. Coding for Onychophora follows Eriksson and Budd (2000) and Eriksson et al. (2003), with the oral/slime papilla identified as segmental equivalent of the tritocerebrum-innervated limb in euarthropods).

116. Single segmented antennal scale: (0) absent; (1) present [G110] (Schram, 1986).

117. Antennal naupliar protopod: (0) short; (1) long [E80] (Sanders, 1963).

118. Distal-less expressed in mandible: (0) present (including transient expression in embryo and in palp); (1) absent in all ontogenetic stages [E81; G112] (Popadić et al., 1998; Scholtz et al., 1998).

119. Mandible (gnathobasic appendage of third limbbearing metamere is main feeding limb of adult head, embedded beneath labrum, lacking Distalless expression at inner margin): (0) absent; (1) present [E82; G113] (Bitsch, 2001; Scholtz, 2001). 
120. Mandibular base plate forming side of head: (0) absent; (1) present [E83] (Manton, 1979).

121. Independently musculated gnathal lobe, flexor arising dorsally on the cranium: ( 0 ) absent; (1) present [G115] (Kluge, 1999; Staniczek, 2000).

122. Pectinate lamellae on mandible: (0) absent; (1) present. See discussion in text ("Mandibular comb lamellae").

123. Mandibular 'shovel' with terminal teeth: $(0)$ absent; (1) present (Koch, 2001).

124. Second (anterior) mandibular articulation with the cranium, movement limited to transverse adduction around a horizontal axis of swing: (0) absent; (1) present [G116] (Fürst von Lieven, 2000; Staniczek, 2000). Arguments that an anterior articulation is present in non-dicondylian hexapods (Collembola, Diplura, Archaeognatha: Koch, 2001) are dismissed by Bitsch (2001); these articulations are non-permanent.

125. Ball-and-socket mandibular articulation: (0) absent; (1) present, formed between clypeal condyle and mandibular ridges [G117] (Fürst von Lieven, 2000; Staniczek, 2000).

126. Mandibular scutes: (0) absent; (1) present (mandible composed of 2-5 movable scutes formed by subdivision of gnathal lobe) [E85] (Boudreaux, 1979).

127. Four sclerites of mandible intersecting at cruciform suture: (0) absent; (1) present. Homologies of particular sclerites/laminae of the mandible in Chilopoda were considered by Manton (1965). Four consistently-defined sclerites in Scolopendromorpha [=laminae condylifera, dentifera, triangularis and manubrii of Crabill (1960)] meet at a cruciform intersection [Nähtekreuz of Verhoeff (1918 in Verhoeff, 1902-1925)]. Coding is confined to the telognathic mandible of myriapods.

128. Mandibular palp: (0) present (appendage of third limb-bearing cephalic metamere with telopodite); (1) absent throughout ontogeny; (2) present in larva, absent in adult [E86; G119].

129. Hand-shaped 'movable appendage' between pałs incisivus and pars molaris on mandible: (0) absent; (1) present (Richter et al., 2002).

130. Posterior tentorial apodemes: (0) absent; (1) present as metatentorium. Posterior tentorial apodemes are lacking in myriapods. Manton (1964) regarded the anatomy, connections, and associated muscles of "posterior tentorial arms" in Collembola and Diplura to indicate homology with the fused posterior tentorial bar (metatentorium) of Ectognatha. Koch (2000) defended this homology, but Bitsch and Bitsch (2002) considered the structures in question (lingual stalks of Collembola; hypopharyngeal apodemes of Diplura - both fulturae sensu Bitsch and Bitsch, 2002) to be entirely exoskeletal structures, and thus not homologous with the endoskeletal formations in insects.
131. Pre- and metatentorium fused: (0) absent; (1) present [G122] (Koch, 2000).

132. Anterior tentorial arms: (0) absent; (1) cuticular tentorium developing as ectodermal invaginations; (2) cuticular fulcro-tentorium. Bitsch and Bitsch (2000: character 20) coded the fulcro-tentorium of Protura (here state 2) as non-homologous with the true tentorium of Ectognatha (state 1), and interpreted the endoskeletal formations of Collembola and Diplura to be a complex endosternite composed of connective fibers rather than a cuticular tentorium. Koch (2000), however, endorsed homology between the anterior tentorial apodemes of Collembola, Diplura and Ectognatha, citing common points of origin, e.g., identical sclerotic connections with the labrum. Bitsch and Bitsch (2002) allow that Folsom's arms of Collembola, which are cuticular structures, are reasonably homologised with the anterior tentorial plates of insects. The slender rods considered as the tentorial apodemes in Diplura (Metajapyx) by Koch (2001) are regarded by Bitsch and Bitsch (2002) as tendons of the mandibular muscle. This point of view implies an absence of anterior apodemes in Diplura.

133. Posterior suspension of anterior apodemes to cranial wall: (0) absent; (1) present [G124] (Koch, 2000) (see discussion of character 132 for Diplura).

134. Anterior tentorium: (0) absent (separate rod-like anterior tentorial apodemes); (1) anterior part of tentorial apodemes forms arched, hollow plates that approach each other mesially but remain separate; (2) anterior tentorium an unpaired roof [G125] (Koch, 2000). ORDERED

135. Swinging tentorium (mandible adbucts by tentorial movements): (0) absent; (1) present [E89] (Manton, 1964).

136. Mandibular articulation with tentorium: $(0)$ gnathal lobe articulates with epipharyngeal bar; (1) mandible articulates with hypopharyngeal bar (Koch, 2003).

137. Suspensory bar from mandible: (0) absent; (1) present [E90] (Boudreaux, 1979).

138. Intergnathal connective lamina: (0) present; (1) absent [G128] (Bitsch and Bitsch, 2000; Staniczek, 2000).

139. Mandibulo-hypopharyngeal muscle: (0) absent; (1) present [G129] (Staniczek, 2000).

140. Complete postoccipital ridge: (0) absent; (1) present [E91] (Staniczek, 2000).

141. Ovigers: (0) absent; (1) present [G131].

142. Salivary glands: (0) arise as ectodermal invaginations on second maxilla/labium; (1) arise as mesodermal segmental organs of first maxillae [E92] (Anderson, 1973).

143. Opening of maxillulary salivary glands: $(0)$ pair of openings at base of second maxillae; (1) median opening in midventral groove of labium; (2) 
median opening in salivarium, between labium and hypopharynx [E93] (Bitsch and Bitsch, 1998).

144. Maxillae on fourth limb-bearing metamere: $(0)$ absent; (1) present [E94].

145. First maxillary precoxal segment: (0) absent; (1) present [E95] (Boxshall, 1998).

146. Number of medially-directed lobate endites on basal podomere of first maxilla: (0) two endites; (1) one endite [E96] (Boxshall, 1998; Walossek, 1999). Applicability to non-crustaceans and possibly homologous endites (e.g., lacinia and galea) are uncertain.

147. First maxillary palps: (0) present (telopodite present on appendage of fourth metamere); (1) absent [E98] (Kraus, 1998).

148. Hypertrophied maxillary palp: (0) absent; (1) present [E99] (Kristensen, 1998).

149. First maxilla divided into cardo, stipes, lacinia, and galea, with similar musculation and function: (0) absent; (1) present [E100] (Manton, 1964; Kluge, 1999).

150. Interlocking of galea and superligua: (0) absent; (1) present [G141] (Kristensen, 1998; Koch, 2001).

151. First maxilla coalesced with sternal intermaxillary plate: (0) absent; (1) present, with unfused stipital and intermaxillary components; (2) mental elements of gnathochilarium consolidated [E101]. Pauropods and diplopods have classically been united based on the maxilla being combined with an intermaxillary plate, with similar embryonic relations between the components (e.g., Dohle, 1980, figs. 10-13). This complex is fused in chilognathan diplopods to form the gnathochilarium (state 2 here). Hilken and Kraus (1994) and Kraus and Kraus $(1994,1996)$ disputed the view that polyxenid diplopods possess a true gnathochilarium (considering the median portion to be the second maxillae) and restrict a "perfect" gnathochilarium to the Chilognatha. As noted by Ax (1999), the structural and functional union of the maxillae in pauropods and diplopods provides an apomorphy regardless of whether or not second maxillae are considered to be incorporated. The consolidation of the mental elements of the gnathochilarium in Chilognatha (Wilson and Shear, 2000), with specialised lobi on the stipes, is scored as a transformation of the unfused stipital/palpal and intermaxillary components in Pauropoda and Penicillata. ORDERED

152. Second maxillae on fifth metamere: $(0)$ appendage developed as trunk limb; (1) well developed maxilla differentiated as mouthpart; (2) vestigial appendage; (3) appendage lacking [E102].

153. Egg tooth on second maxilla: $(0)$ absent (no embryonic egg tooth on cuticle of fifth limb-bearing metamere); (1) present [E103] (Dohle, 1985).

154. Maxillary plate [basal parts of fifth limb-bearing metamere (second maxilla or labium) medially merged, bordering side of mouth cavity]: (0) absent; (1) present [E97] (Kraus and Kraus, 1994; Dohle, 1998).

155. Coxae of second maxilla medially fused: $(0)$ absent (coxae of fifth metamere not fused); (1) present [E104] (Dohle, 1985).

156. Comb-like fringe of simple bristles on tarsus of telopod of second maxilla: (0) absent; (1) present. Scolopendromorpha have a comb-like fringe along the side of the tarsus of the second maxillary telopodite [see, e.g., Scolopendra (Attems 1930, figs. 61, 63; Borucki 1996, fig. 49); Cryptops (Attems 1930, fig. 12)]. Borucki (1996, fig. 47) identified putatively homologous elements, the kapillare Besen, in Craterostigmus. The scolopendromorph kapillare Besen differ from those of Craterostigmus in that a denser fringe of simple bristles arises as outgrowths of a narrow band. In Craterostigmus, the fringe is composed of bifurcating or multifurcating spines that arise directly from the edge of the telopodite, and intergrade with the terminal claw.

157. Symphylan-type labium (anterior plate with a row of papilla-bearing lobes distally and tapering proximal arms that extend back to a pair of cervical sclerites): (0) absent; (1) present [G146] (Kraus and Kraus, 1994, 1996).

158. Linea ventralis: (0) absent; (1) present [E105] (Koch, 1997).

159. Divided glossae and paraglossae: (0) undivided pair of glossae and paraglossae; (1) glossae and paraglossae bilobed [E106] (Kristensen, 1991).

160. Rotation of labial Anlagen: (0) absent; (1) present [G149] (Ikeda and Machida, 1998).

161. Widened apical segment of labial palp: (0) absent; (1) present [G150] (Kristensen, 1998).

162. Collum covering posterior part of head capsule and part of segment II: (0) absent; (1) present [G152] (Enghoff, 1984).

163. Direct articulation between first and fourth articles of telopodite of maxilliped: (0) absent; (1) present [E107] (Attems, 1926).

164. Coxosternite of maxilliped sclerotised in midline: (0) coxae separated medially, with sternite present in adult; (1) coxosternal plates meeting medially, with flexible hinge; (2) coxosternal plates meeting medially, hinge sclerotised and non-functional [E108] (Shear and Bonamo, 1988). ORDERED

165. Maxilliped coxosternite deeply embedded into cuticle above second trunk segment: $(0)$ not embedded; (1) embedded [E109] (Manton, 1965).

166. Maxilliped segment with pleurite forming a girdle around coxosternite: (0) small lateral pleurite; (1) large girdling pleurite [E110] (Manton, 1965).

167. Tergite of maxillipede segment fused with tergite of first pedigerous segment: (0) separate tergites; (1) single tergite. Fusion of the maxillipede tergite to the first pedigerous trunk tergite is unique to Scolopendromorpha. 
168. Sternal muscles truncated in maxilliped segment, not extending into head: $(0)$ sternal muscles extended into head; (1) sternal muscles truncated [E111] (Manton, 1965).

169. Maxilliped tooth plate (anteriorly-projecting, serrate coxal endite): (0) absent; (1) present [E112] (Shear and Bonamo, 1988).

170. Maxilliped poison gland: (0) absent; (1) present [E113].

171. Maxilliped distal segments fused as a tarsungulum: (0) separate tarsus and pretarsus; (1) tarsus and pretarsus fused as tarsungulum [E114] (Borucki, 1996).

172. Oblique muscle layer in body wall, with fibres organised in a chevron pattern: (0) absent; (1) present [E115] (Storch and Ruhberg, 1993).

173. Longitudinal muscles: (0) united sternal and lateral longitudinal muscles; (1) separate sternal and lateral longitudinal muscles, with separate segmental tendons [E116] (Manton, 1965).

174. Superficial pleural muscles: (0) absent; (1) present [E117] (Manton, 1965).

175. 'Box truss' trunk axial musculature including crossed, oblique dorsoventral muscles, paired anterior and posterior oblique muscles: (0) absent; (1) present [E118]. The dorsoventral suspensors of the endosternum and the abdominal dorsoventral muscles of arachnids lack certain muscles, e.g., anterior oblique muscles (Shultz, 2001) of the box-truss arrangement of mandibulates, but Shultz (2001) indicated that the axial muscles of the abdomen in Limulus share all components.

176. Deep dorsoventral muscles in the trunk: (0) absent; (1) present [E119] (Manton, 1965).

177. Circular body muscle: (0) present; (1) suppressed [E120].

178. Discrete segmental cross-striated muscles attached to cuticular apodemes: (0) absent; (1) present [E121] (Nielsen, 1995).

179. Abdominal muscles: (0) straight; (1) twisted [E 122] (Manton, 1972).

180. Proventriculus in the foregut: (0) absent; (1) present [E123] (Bitsch and Bitsch, 1998; Klass, 1998)]

181. Lateralia and inferolateralia in the cardiac chamber: (0) absent; (1) present [G170] (Richter and Scholtz, 2001).

182. Unpaired superomedianum at transition from cardia to pyloric chamber: (0) absent; (1) present [G171] (Richter and Scholtz, 2001).

183. Inferomedianum anterius (midventral cardiac ridge): (0) absent; (1) present [G172] (Richter and Scholtz, 2001).

184. Inferomedianum posterius (midventral pyloric ridge): (0) absent; (1) present [G173] (Richter and Scholtz, 2001).

185. Atrium between the inferomediana connecting the cardiac primary filter grooves with the pyloric filter grooves: (0) absent; (1) present [G174] (Richter and Scholtz, 2001).
186. Gut caeca: (0) absent; (1) present along midgut; (2) restricted to anterior part of midgut [E124; G175] (Clarke, 1979; Bitsch and Bitsch, 1998).

187. Proctodeal dilation: (0) posterior section of hindgut simple, lacking a dilation; (1) proctodeum having a rectal ampulla with differentiated papillae [E125] (Bitsch and Bitsch, 1998).

188. Peritrophic membrane: (0) absent; (1) present [E126] (Clarke, 1979).

189. Radiating, tubular diverticula with intracellular final phase of digestion: (0) absent; (1) present [E127] (Snodgrass, 1952).

190. Prosomal / opisthosomal boundary: (0) absent; (1) behind sixth prosomal appendage pair [E128] (Waloszek and Dunlop, 2002).

191. Transverse furrows on prosomal carapace corresponding to margins of segmental tergites: $(0) \mathrm{ab}$ sent; (1) present [E129] (Shultz, 1990).

192. Fusion of all (opisthosomal) tergites behind opercular tergite into a thoracetron: (0) absent; (1) present [G181] (Anderson and Selden, 1997).

193. Opisthosoma greatly reduced, forming a slender tube emerging from between the posteriormost legs, with terminal anus: (0) absent; (1) present [G182].

194. Lamellate respiratory organs derived from posterior wall of opisthosomal limb buds: (0) absent; (1) present [G183] (Dunlop 1998).

195. Position of lamellate respiratory organs: $(0)$ on opisthosomal segments $3-7$; (1) on opisthosomal segments $4-7$; (2) on opisthosomal segments 2-3 [G184].

196. Type of lamellate respiratory organs: (0) book gills; (1) book lungs [G185].

197. Appendage on first opisthosomal segment: (0) appendage present on first opisthosomal segment in post-embryonic stages; (1) appendage absent [E131; G186] (Shultz, 1990).

198. Limb VII as chilaria: (0) absent; (1) present [G187].

199. First opisthosomal segment: (0) broad; (1) narrow, developed as pedicel [G188] (Shultz, 1990; Dunlop, 1996).

200. Abdomen (limb-free somites between the terminal segment and limb-bearing trunk segments, posterior to expression domain of $U b x, a b d A$ and $a b d B)$ : (0) absent; (1) present [E137] (Grenier et al., 1997).

201. Pereion tagmosis: (0) one locomotory tagma; (1) two locomotory tagmata [E138; G190] (Walossek, 1999; Abzhanov and Kaufman, 2000).

202. Thorax with three limb-bearing segments: (0) absent; (1) present [E139].

203. Meso- and metathorax in mature stages bearing wings: (0) absent; (1) present [G192].

204. Wing flexion: (0) absent; (1) present [G193] (Hennig, 1969).

205. Segmentation of pleon: (0) seven segments; (1) six segments (including sixth pleomere fused with telșon) [G194] (Richter and Scholtz, 2001). 
206. Diplosegments: (0) absent; (1) present [E140] (Enghoff, 1984).

207. Endosternum (ventral tendons fused into prosomal endosternum): (0) absent; (1) present [E141]. Various arthropods have mesodermally-derived endoskeletal structures composed of a matrix of fibrils (summarised by Bitsch and Bitsch, 2002) but the chelicerate endosternum can be characterised by its consolidation of multiple prosomal tendons and serving as the attachment site of many extrinsic muscles of the pedal coxae (Firstman, 1973; Shultz, 2001).

208. Dorsal endosternal suspensor of fourth postoral segment with anterolateral carapacal insertion: (0) absent; (1) present [G197] (Shultz, 1990).

209. Tergal scutes extend laterally into paratergal folds: (0) absent; (1) present [E142; G198] (Boudreaux, 1979).

210. Paramedian sutures: (0) absent; (1) present [E143] (Manton, 1965).

211. Intercalary sclerites: (0) absent; (1) developed as small rings; (2) developed as pretergite and presternite [E144] (Manton, 1965; Dohle, 1985). ORDERED

212. Trunk heterotergy: (0) absent; (1) present (alternating long and short tergites, with reversal of lengths between seventh and eighth pedigerous segments) [E145] (Borucki, 1996).

213. Trunk sternites: (0) each segment with large sternum; (1) sternal area divided into two hemisternites by linea ventralis; (2) sternal area mostly membranous, with pair of small sternites; (3) sternal plate (at least that of thoracic segments II and III) bears a Y-shaped ridge/apodeme; (4) sternites extended rearwards to form substernal laminae; (5) thoracic sternal areas reduced and partly invaginated along median line; (6) sternites lacking [G202] (Bitsch and Bitsch, 2000).

214. Trunk endoskeleton in each segment: (0) pair of lateral connective plates; (1) pair of sternocoxal rods (ventral apodemes); (2) complex connective endosternite; (3) endoskeleton mainly cuticular, composed of two intrasegmental furcal arms and an intersegmental spinal process [G203] (Bitsch and Bitsch, 2000; Klass and Kristensen, 2001).

215. Pleural part of trunk segments: (0) pleurites absent; (1) supracoxal arches (catapleural and anapleural arches) on each segment; (2) pleural part of thoracic segments II and III consisting of single sclerite with large pleural process; (3) pleuron in each thoracic segment consists of single sclerite divided into anterior and posterior parts by pleural suture, from which pleural apophysis is invaginated, internal end connected to furcal arm [G204] (Bitsch and Bitsch, 2000).

216. Procoxal and metacoxal pleurites surround coxa: (0) pleurites absent or incompletely surrounding coxa; (1) procoxa and metacoxa surround coxa [E147].
217. Elongate coxopleurites on anal legs: $(0)$ absent; (1) present [E148] (Borucki, 1996).

218. Pleuron filled with small pleurites: (0) absent; (1) present [E149].

219. Complete body rings: (0) absent (sternites and/or pleurites free); (1) present (Enghoff et al. 1993).

220. Longitudinal muscles attach to intersegmental tendons: (0) absent; (1) present [E150] (Boudreaux, 1979).

221. Lobopods with pads and claws: (0) absent; (1) present [E133].

222. Articulated limbs with intrinsic muscles: (0) absent; (1) present [E135] (Nielsen, 1995).

223. Fundamentally biramous post-antennal limbs (endopod and exopod): (0) absent; (1) present [E136; G213] (Walossek and Müller, 1998a, b).

224. Coxopodite(s) with gnathobasic endite lobes medially: (0) absent; (1) present [E151; G214] (Wägele and Stanjek, 1995).

225. Protopod composed of basis and coxa or proximal endite: (0) absent; (1) present [E160; G215] (Walossek and Müller, 1990, 1998a, b).

226. Paddle-like epipods: (0) absent; (1) present [E166] (Hessler, 1992).

227. Trunk limbs with lobate endites formed by folds in limb bud, with indistinct proximal-distal axis of polarity: (0) absent; (1) present [E167] (Williams, 1999; Schram and Koenemann, 2001).

228. Coxal swing: (0) coxa mobile, promotor-remotor swing between coxa and body; (1) coxa with limited mobility or immobile, promotor-remotor swing between coxa and trochanter [E152].

229. Coxopodite articulation: (0) arthrodial membrane; (1) pleural condyle; (2) sternal condyle; (3) sternal and pleural condyles; (4) internal plate [E153; G219] (Manton, 1972).

230. Coxal vesicles: (0) absent; (1) present at limb base on numerous trunk segments; (2) on distal part of first abdominal appendage [E155] (Dohle, 1980; Klass and Kristensen, 2001).

231. Styli: (0) absent; (1) present [E156] (Dohle, 1980).

232. Musculi laterales: (0) absent; (1) present [G223] (Shultz, 1990).

233. Coxotrochanteral joint: (0) simple; (1) complex [G224] (Shultz, 1989, 1990).

234. Trochanteronotal muscle: (0) absent; (1) present [G225] (Bitsch and Bitsch, 2000).

235. Trochanter distal joint: (0) mobile; (1) short, ringlike trochanter lacking mobility at joint with prefemur [E157] (Manton, 1965).

236. Trochanterofemoral joint of walking legs: $(0)$ transverse bicondylar; (1) vertical bicondylar [G227] (Shultz, 1989, 1990).

237. Unique trochanteral femur-twisting muscle: (0) absent; (1) present [G228] (Kristensen, 1998).

238. Monocondylic femur-tibia pivot joint: (0) absent; (1) present [G229] (Kristensen, 1998).

239. Patella/tibia joint: (0) free; (1) fused [E168] (Kristensen, 1991). 
240. Patellotibial joint of walking legs: (0) dorsal monocondylar; (1) simple bicondylar; (2) vertical bicondylar [E169; G231] (Shultz, 1989, 1990).

241. Femoropatellar joint: (0) transverse dorsal hinge; (1) bicondylar articulation [E170] (Shultz, 1989, 1990).

242. Origin of posterior transpatellar muscle: $(0)$ arises on distodorsal surface of femur, traverses femoropatellar joint ventral to axis of rotation, receives fibres from wall of patella; (1) arises on distal process of femur, traverses femoropatellar joint dorsal to axis of rotation, does not receive fibres from patella [E171; G233] (Shultz, 1989).

243. Elastic arthrodial sclerites spanning tibia-tarsus joint: (0) absent; (1) present [G234] (Shultz, 2000).

244. Tarsus segmentation: (0) not subsegmented; (1) subsegmented [E173].

245. Tarsal organ: (0) absent; (1) present [G236] (Selden et al., 1991).

246. Origin of pretarsal depressor muscle: (0) pretarsal depressor originates on tarsus; (1) pretarsal depressor originates on patella [E 158; G237] (Shultz, 1990).

247. Pretarsal levator muscle: (0) present; (1) absent (depressor is sole pretarsal muscle) [E159] (Snodgrass, 1952).

248. Pretarsal claws: (0) paired; (1) unpaired [E172; G239].

249. Pretarsal claw(s) articulation: (0) on pretarsal base; (1) on distal tarsomere [E174] (Beutel and Gorb, 2001).

250. Plantulae: (0) absent; (1) present [G241] (Minet and Bougoin, 1986).

251. Tracheae/spiracles: (0) absent; (1) pleural spiracles; (2) spiracles at bases of walking legs, opening into tracheal pouches; (3) single pair of spiracles on head; (4) dorsal spiracle opening to tracheal lungs; (5) open-ended tracheae with spiracle on second opisthosomal segment; (6) many spiracles scattered on body [E161] (Hilken, 1998).

252. Longitudinal and transverse connections between segmental tracheal branches: (0) tracheae not connected; (1) tracheae connected [E162] (Dohle, 1985; Bitsch and Bitsch, 1998).

253. Pericardial tracheal system with chiasmata: (0) dendritic tracheae; (1) long, regular, pipe-like tracheae with specialised moulting rings [E163] (Hilken, 1997).

254. Abdominal spiracles: (0) present (pleural spiracles on posterior part of trunk); (1) absent on first abdominal segment; (2) absent on all abdominal segments [E164] (Štys and Bilinski, 1990; Larink, 1997).

255. Spiracle muscles: (0) absent; (1) present. Muscles with an apodemal function insert on the dorsal and ventral sides of the subatrial pocket/tracheal pouches in scolopendromorphs, e.g., Scolopendra and Cryptops, but not in other chilopods examined by Füller (1960) or Hilken $(1997,1998)$.
256. Abdominal segmentation: (0) six segments; (1) 10 segments; (2) 11 segments; (3) 12 segments [G246] (Ikeda and Machida, 1998).

257. Annulated caudal filament: (0) absent; (1) present [E176] (Kristensen, 1998).

258. Abdominal segment XI modified as cerci: (0) absent; (1) present [E178] (Kristensen, 1991).

259. Articulate furcal rami: (0), absent; (1) present [E179] (Walossek and Müller, 1992).

260. Uropods: (0) absent; (1) present [G250] (Richter and Scholtz, 2001).

261. Styliform post-anal telson: (0) absent; (1) present [G251] (Bergström et al., 1980).

262. Paired terminal spinnerets: (0) absent; (1) present [G252] (Kraus and Kraus, 1994).

263. Anal segment with a pair of large sense calicles, each with a long sensory seta: (0) absent; (1) present [G253] (Scheller, 1982).

264. Egg cluster guarded until hatching, female coiling around egg cluster: (0) absent; (1) females coils ventrally around cluster; (2) female coils dorsally around cluster [E180] (Dohle, 1985; Bonato and Minelli, 2002).

265. Peripatoid and foetoid stages protected by mother: (0) absent; (1) present [G255] (Dohle, 1985).

266. Female gonopod used to manipulate single eggs: (0) absent; (1) present [E182] (Ax, 1999).

267. Female abdomen with ovipositor formed by gonapophyses of segments VIII and IX: (0) absent; (1) present [E183; G257] (Bitsch and Bitsch, 2000).

268. Gonangulum sclerite fully developed as ovipositor base, articulating with tergum IX and attached to $1^{\text {st }}$ valvula/valvifer: (0) absent; (1) present [E184] (Kristensen, 1981, 1998).

269. Ovipositor opening at anteroventral part of opisthosoma: (0) absent; (1) present [G259] (Shultz, 1990; Giribet et al., 2002).

270. Legs on seventh trunk segment transformed into gonopods: (0) absent; (1) present [G260] (Enghoff et al., 1993).

271. Dignathan-type penes: (0) absent; (1) present [E186] (Dohle, 1980).

272. Penis (spermatopositor) opening on anteroventral part of opisthosoma: (0) absent; (1) present [G262] (Giribet et al., 2002).

273. Male parameres: (0) undifferentiated; (1) pair of 'lateral plates' on segment XI; (2) pair of parameres on segment IX (second pair variably present on segment VIII); (3) incorporated into phallic apparatus as sclerites [G263] (Bitsch and Bitsch, 2000).

274. Penis on abdominal segment IX: (0) absent; (1) present [G264] (Bitsch and Bitsch, 2000).

275. Male gonopore location: $(0)$ posterior end (opisthogoneate); (1) somite 11 (sixth pereion segment); (2) somite 12 (seventh pereion segment); (3) somite 8 (first opithosomal segment); (4) behind legs of somite 8 (second pair of trunk legs); (5) somite 13 (eighth pereion segment); (6) somite 17 (twelfth 
pereion segment); (7) somite 16 ; (8) on multiple leg bases; (9) between segments VIII and IX, more or less hidden by hind border of sternum VIII; (A) somite 19 (fourteenth trunk segment) [E187; G265].

276. Female gonopore position: (0) on same somite as male; (1) two segments anterior to male; (2) six segments anterior to male; (3) seven segments anterior to male [E188; G266].

277. Genital operculum divided, incorporated into pedicel: (0) absent; (1) present [G267] (Shultz, 1990).

278. Genital operculum overlapping third opisthosomal sternite: (0) absent; (1) present [G268] (Shultz, 1990; Dunlop, 1999).

279. Postgenital appendages: (0) opercular and/or lamellar; (1) poorly sclerotized or eversible; (2) absent [G269] (Shultz, 1990).

280. Embryonic gonoduct origin: (0) gonoduct arising as a mesodermal coelomoduct; (1) gonoduct arising as a secondary ectodermal ingrowth; (2) gonoduct arising in association with splanchnic mesoderm [E189] (Anderson, 1973).

281. Lateral testicular vesicles linked by a central, posteriorly-extended deferens duct: (0) absent; (1) present [E191] (Prunescu, 1996).

282. Testicular follicles with pectinate arrangement: $(0)$ absent (elongated testicular sac or sacs); (1) several pectinate follicles present [E192] (Bitsch and Bitsch, 1998).

283. Spermatophore web produced by 'Spingriffel' structure: (0) absent; (1) present [E193; G274] (Dohle, 1985).

284. "By-passing" foreplay, spermatophore transfer on web, "waiting" ritual by female: (0) absent; (1) present [G275] (Sturm, 1997).

285. Bean-shaped spermatophore with tough multilayered wall: (0) absent; (1) present (Edgecombe et al., 1999: character 112).

286. Sperm dimorphism: (0) absent; (1) present (microsperm and macrosperm) [E194; G276] (Carcupino et al., 1999; Dallai and Afzelius, 2000). See Giribet et al. (2001: footnote to character 276) for taxonomic sampling of sperm characters.

287. Acrosomal complex in sperm: (0) filamentous actin perforatorium present; (1) monolayered (perforatorium absent); (2) acrosome absent [E195; G277] (Jamieson et al., 1999).

288. Perforatorium bypasses núcleus: (0) absent (perforatorium penetrates nucleus); (1) present [G278] (Jamieson, 1991).

289. Periacrosomal material: (0) absent; (1) present [G279] (Jamieson, 1987).

290. Striated core in subacrosomal space: (0) absent; (1) present [G280] (Baccetti and Dallai, 1978; Dallai and Afzelius, 2000).

291. Centrioles in sperm: (0) proximal and distal centrioles present, not coaxial; (1) coaxial centrioles; (2) single centriole; (3) centrioles absent in ma- ture sperm; (4) doublet centrioles, each with a radial 'foot' [E196; G281] (Jamieson et al., 1999).

292. Centriole adjunct: (0) absent; (1) present [E197; G282] (Jamieson et al., 1999).

293. Sperm 'accessory bodies' developed from the centriole: (0) absent; (1) present [E198] (Jamieson, 1987; Dallai et al., 2003).

294. Cristate, non-crystalline mitochondrial derivatives in sperm: (0) absent; (1) present [E199] (Jamieson, 1987).

295. Connecting bands between axoneme and mitochondria: (0) absent; (1) present (Dallai et al., 2003).

296. Supernumary axonemal tubules (peripheral singlets): (0) absent; (1) formed from the manchette; (2) formed from axonemal doublets [E200] (Dallai and Afzelius, 1993, 1999).

297. Number of protofilaments in wall of accessory tubules: (0) 13; (1) 16 (Dallai and Afzelius, 1999).

298. Axonemal endpiece 'plume': (0) endpiece not extended; (1) endpiece extended, plume-like [E201] (Jamieson, 1986).

299. Sperm flagellum: (0) present; (1) absent [E203].

300. Nucleus of sperm forms spiral ridge: (0) absent; (1) present*[E202; G288] (Dohle, 1985; Alberti, 1995).

301. Nucleus of sperm with a manchette of microtubules: (0) absent; (1) present [G289] (Alberti, 1995).

302. Coiling of spermatozoan flagellum: (0) absent (filiform sperm); (1) present [G290] (Alberti, 1995).

303. Medial microtubules in spermatozoan axoneme: (0) two $(9+2) ;(1)$ three $(9+3)$; (2) none $(9+0)$ [G291] (Alberti, 1995).

304. Sperm conjugation: (0) absent; (1) present [G292] (Dallai et al., 2001).

305. Female spermathecae formed by paired lateral pockets in mouth cavity: (0) absent; (1) present [G293] (Kraus, 1998).

306. Ovary shape: (0) sac- or tube-shaped, entire; (1) divided into ovarioles; (2) ovarian network [E204] (Makioka, 1988; Štys et al., 1993).

307. Asymmetry of oviducts and ejaculatory ducts: (0) left and right ducts symmetrical; (1) left ducts rudimentary or absent. Dominance or presence of the right ejaculatory duct alone is shared by Scolopendromorpha, including Cryptops and Scolopendra (Prunescu, 1997) but not other chilopods. Most scolopendromorphs, including Cryptops and Scolopendridae, also have at most a rudimentary left oviduct (Prunescu, 1997).

308. Location of ovary germarium: (0) germarium forms elongate zone in the ventral or lateral ovarian wall; (1) germarium in the terminal part of each egg tube; (2) single, median mound-shaped germarium on the ovarian floor; (3) paired germ zones on ovarian wall [E205; G295] (Makioka, 1988; Yahata and Makioka, 1994; Bitsch and Bitsch, 1998).

309. Site for oocyte growth: (0) in ovarian lumen; (1) 
on outer surface of ovary, in hemocoel, connected by egg stalk [E206] (Makioka, 1988; Ikuta and Makioka, 1999).

310. Coxal organs: (0) absent; (1) present [E207] (Rosenberg, 1983).

311. Crural glands: (0) absent; (1) present [E208] (Storch and Ruhberg, 1993; Monge-Nájera, 1995).

312. Pair of repugnatorial glands in the carapace: $(0)$ absent; (1) present [G299] (Giribet et al., 2002).

313. Pleural defense glands with benzoquinones: $(0)$ absent; (1) present [G300] (Enghoff, 1984).

314. labial expression domain: (0) expressed over multiple segments; (1) expression confined to second antennal/intercalary segment. The Hox gene $l a-$ bial has strong expression in the pedipalp segment of arachnids (the araneomorph Cupiennus coded as a proxy for Mygalomorphae; Damen et al., 1998) and in the intercalary segment in Lithobius (Hughes and Kaufman, 2002a), and weak or transient expression in additional, more posterior segments. In crustaceans and insects, labial expression is confined to the second antennal and intercalary segments, respectively (Hughes and Kaufman, 2002a, b) (Diederich et al., 1989 for Drosophila). Codings use data from Porcellio (Abzhanov and Kaufman, 1999) for Onsicidea, and Thermobia (Peterson et al., 1999) as a representative of Lepismatidae.

315. proboscipedia expression domain: (0) colinear with labial and Deformed domains; (1) anterior boundary of main expression domain of proboscipedia behind anterior boundary of Deformed. The general condition of colinearity of Hox genes upstream is altered in insects (Abzhanov and Kaufman, 1999), in which the main expression of proboscipedia is in the maxilla and labium. This is shared by Thermobia, in which $p b$ expression more anteriorly (in the intercalary segment) is weak and transient.

316. Deformed expression domain: (0) expressed over three or more segments; (1) expression confined to mandibular and first maxillary segment. Deformed expression in arachnids is strong on all four walking leg segments, and on the mandibular and both maxillary segments in Lithobius (Hughes and Kaufman, 2002a, b). It is expressed on the mandibular and first maxillary segments alone in crustaceans and insects. Taxonomic sampling is as in the preceding character, with Steatoda and Achaearanea (Abzhanov et al., 1999) providing additional data for spiders.

317. Antennapedia expression domain: (0) strong throughout trunk; (1) restricted from the posterior of embryo (Hughes and Kaufman, 2002b).

318. Relative position of $\mathrm{COI}$ and COII: $(0) \mathrm{COI} / \mathrm{COII}$; (1) $\mathrm{COI} / \mathrm{tRNA}{ }^{\mathrm{L}(\mathrm{UUR})} / \mathrm{COII}[\mathbf{E 2 1 0} ; \mathbf{G 3 0 2}]$ (Boore et al., 1995, 1998; Lavrov et al., 2002).

319. Relative position of tRNA $\mathrm{L}^{\mathrm{L}(\mathrm{CUN})}$ : (0) l-rRNA/ tRNA $^{\text {L(CUN)/ND1; (1) l-rRNA/ tRNA }}{ }^{\text {L(CUN) }}$ /

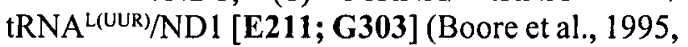
1998).

Table 1 - Codings for 319 characters listed in Appendix 1. Multistate taxa are in the form "(1/2)" (=either 1 or 2 but not 0 ).

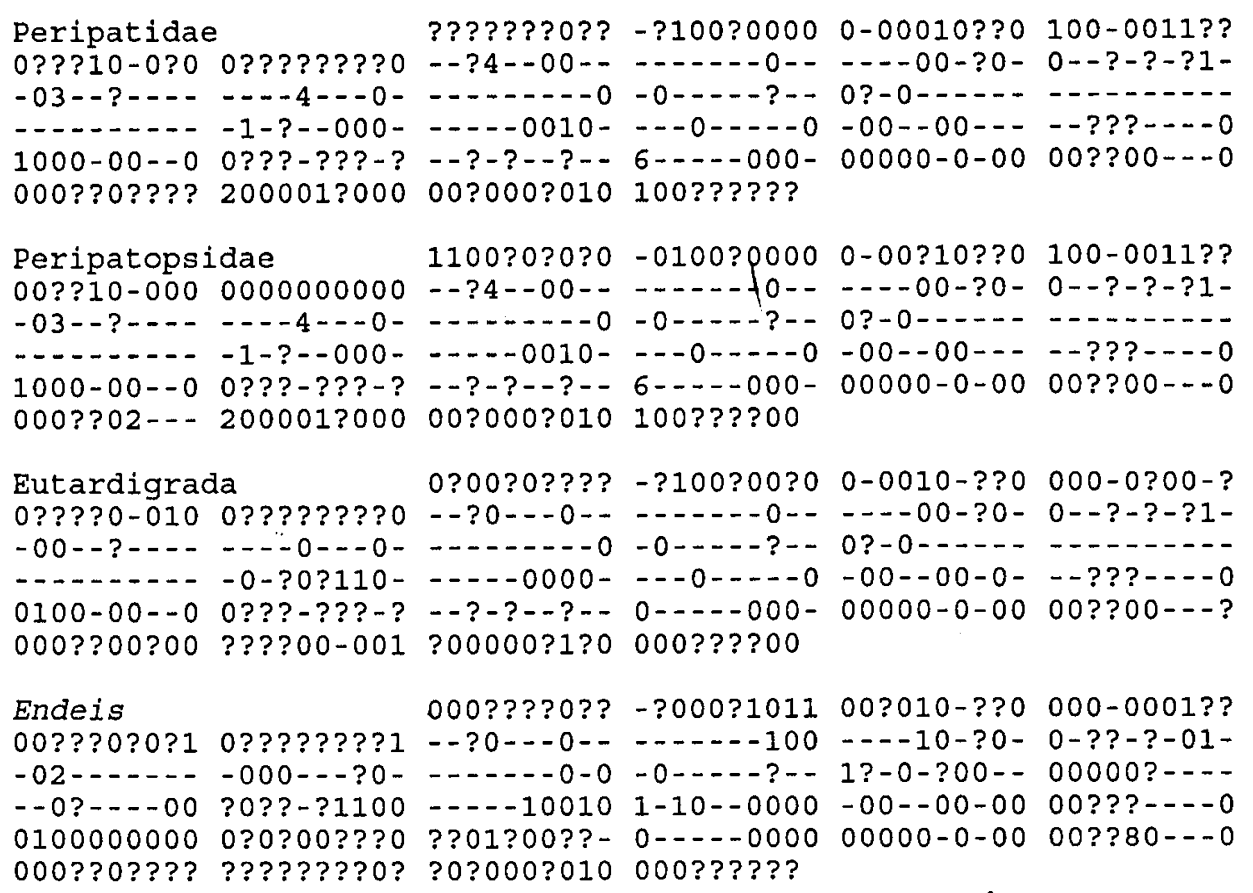


Table 1 - Continued.

\section{Colossendeis} 00???0?0?1 0???????? 1 -0-.-..- - -003--?0$--0 ?---00$ ?0??-?1100 0100000000 0?0?00???0 000??????? ??????????

\section{Ammotheidae}

00??00?0?1 00??100001

$-02-----0003--? 0-$

$--0 ?---00$ ?0??-?1100

0100000000 0?0?00???0

000??0???? ????????0?

Limulus

00??0000?1 1010100001

$002-\ldots-0000--00-$

--0 ?--- -00 ?0??1?1100

0111000000 000?00???0

000??00000 100000-000

???????0?? -??00?1011 00?010-??0 000-0001?? - ?0--0-_ - $0-100-10-10-0-$ ? ?-?-01----0-0 -0----?-- 1?-0-?00-- 00000?--.----10010 1-10--0000 -00--00-00 00???----0 ??01?00??- 0----0000 00000-0-00 00??80---0 ????00???0 000??????

0?0????0?? -?000?1011 00?010-??0 000-0001?? --?0---0-- - - $0-100---10-? 0-0-? ?-?-01-$ - - - -0-0 -0----?-- 1?-0-?00--00000?----.--10010?-10--0000-00--00-00 00???---00 ??01?00??- 0-----0000 00000-0-00 00??80---0 ?0?000???0 000??????

0101?0?0?? 0?100?1011 00?0111?00 000-0001?? --?3000100 ----?10300 --??00-210 0-00-?-000 --1--0-0 -0----?-- 0?-0-?00-- 00000?-----100110101000100 -00--01010 00???---01 0000?00??- 0----0000 10000-0-00 00??30000? $000002 ? 010000 ? ? ? ? 00$

0101?0?0?2 0?100?1011 00?0?11?00 000-0?01?? --?30001?0 ----?10300 - -??00-210 0-00-?-000 ---100110101000100 -00--01010 00???---01 0000?00??- 0----0000 10000-0-00 00??30000? 002002 ?010 000??????

0100?0?0?? 0?100?10110010?11?00 010-0001?? Buthidae $10 ? ? 001011101 ? 100001--? 1-0000-000-0310--? ? 0100100-00-?-001$ --0?--100 ?0??0?1100 -..-10011 $1001111000-00--01010$ 00???---01 01010001-0 000?00???1 1111010??- 0----0000 10000-0-00 00??300000 $0000000 ? 00100000-000$ 002002?010 000????00

Mygalomorphae 10???01011 1?1??????1 $002-----11-3-00-$ $--0 ?---00$ ?0??0?1100 01000001-0 011?00???0 000??0??? 100000--01

Mastigoproctus 1???0010?1 10101000?1 002--.-.-11-3--?0--0 ?--- 00 ?0??0?1100 01000001-0 011?00???0 000??00?00 100000--01

Phalangiidae

1???000011 1010100001

$102--\ldots-0013--? 0-$

$--0 ?---00$ ?0??0?1100

01010001-0 000?01???2

000??02-- - 0-0-- 10

Nipponopsalis

1????000?1 1??????? 1

$102-1---00 ? 3--? 0-$

$--0 ?---00$ ?0? ?0? 1100

01010001-0 $000 ? 01 ? ? ? 2$

Equitius

1????000?1 1????????1
0100?0?0?2 1?100?1011 00?0?11?10 010-0001?? --?1--0000 ---?-1310 - ??010010 0-01-?-000 -..--0-0 -0---?- - 0?-0-?00-- 00000?-$-\ldots-100110001211010-00--0110000 ? ? ?---01$ 0001110 ?? - 0-..-0000 00000-0-00 00??301110 $111000 ? 0100000000$ ??

???????0?? 1?100?1011 00?0?11?10 010-0001?? --?1--00?0 ----?-1310 --??010010 0-01-?-000 -.---0-0 -0--..-?-- 0?-0-?00-- 00000?---.-100110001211010 -00--01100 00???---01 0001110??- 0----0000 00000-0-00 00??301120 111000 ?010 000??????

0?00?0?0?? ??100?1011 00?0?11?00 000-0?01?? --?0---0------0-0 -0----?-- 0?-0-?00-- 00000?---- $\because-10011$ 1000--1000-00--01000 00???---01 1111010??- 5----0000 00000-0-10 01??30002? 0--000??10 010??????

???????0?? ??100?1011 00?0?11?00 000-0?01?? --?0---0- - - - - 0-0 -0-_-? - 0?-0-?00-- 00?00?------10011 1000--1000-00--01000 00???---01 1?11010??- 5--.-0000 00000-0-10 01??30002? ????00???0 010??????

1. ???????0?? ??100?1011 00?0?11?00 000-0?01?? -- ?0--0-_ - 
Table I-Continued.

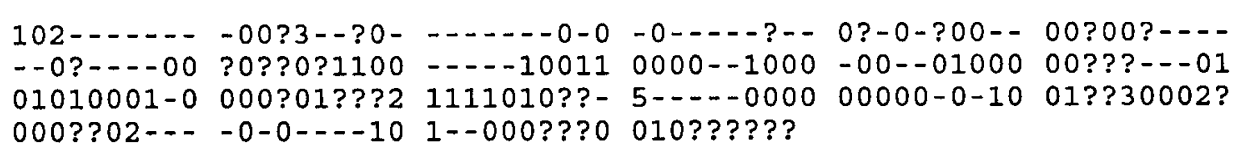

Scutigeridae

00???01012 0???????? 1

$-01000100-0---2--? 10$

?-00000001 0000101100

0101000020 0??01???0?

0000010000 210000-101

\section{Lithobius}

0 ???001012 001?000011

$-01000000-0---2--? 10$

?-01000001 1000101100

0101000020 0??01???0?

0010011-00 210000-101

\section{Craterostigmus}

0 ????0?0?2 0???????? 1

-01000000 ? $0---2--? 10$

?-02110111 1011111100

0101000020 0??01???0?

101?0?1-00 ?100???101

\section{Cryptops}

0????0?012 0????????

$-01000000-0---2--? 10$

?-12111101 1011111100

0101000020 0??01???0?

101?111-00 210000-101

Scolopendridae

000??01012 0011000011

-01000000- 0---2--?10

$?-12111111 \quad 1011111100$

0101000020 0??01???0?

1010111-00 210000-101

\section{Mecistocephalus}

0????010?2 0???????? 1

$-01001000-0---2--? 10$

?-12110101 1011111100

0101000020 0???1???0?

101 ?????? ?????????

Chilenophilidae

0????010?2 0????????

-01001000- 0---2--?10

?-12110101 1011111100

0101000020 0???1???0?

101?001-00 210000-101

Hanseniella

00???000?2 0???????? 1

$-01000000-0---2--? 11$

--00-00000 00??1?1100

01010000211 ??00???0?

000??????? ?????????

Scutigerella

0 ????000?2 0???????? 1

-01000000- 0---2--?11

$-00-000000000101100$
??01?0?\{1/2\}?? -?0000101100?1?11201 0010000100

$00 ? 2--0010-? ? ? ? 000----0000-010000 ?-0010-$

110-10100-10000100-0001-?000-0110000---

---00100 -0-0---0-0 -00--00-00 010?100001

?-?1??110-400-0-0000 0000010-00 000000---0

0000000 ??0 000?????

???????\{1/2\}?? -?00001011 01?1?11201 0010000101

$0102--0000----?-00---0000-010000 ?-0010-$

110--10100-10010100-0001-?000-0110100---

- - - -00100 -0-0---0-0 -00--00-00 0100100001

?-?1??110-10000-0000 0000010-00 000000---?

0000000001000000100

???????\{1/2\}?? -?000?1011 01???11001 00100?0110

0102--00?? ???????0-- - -0000-010 000?-0010-

110--10100-10010100-0001-?000-01?0100---

$---00 ? 00-0-0---0-0 \quad-00--00-00 \quad 110 ? 101001$

?-?0??110-10000-0000 00010-0-00 000000---?

00??000??1 000??????

???????\{1/2\}?? -?100?1011 00?0?11000 00100?01??

0100---0--

110--11100-10010100-0001-?000-0110110---

110--00?00 -0-0---0-0 -00--00-01 2100111001

?-?0??110-11001-0000 00011-0-00 000000---?

$0000001 ? ? 1$ 000??????

$010000 ? 200-0100 ? 1011001 ? ? 110000010000110$

0102--0000 - - ?-00-- - -0000-010 000?-0010-

110--11100-10010100-0001-?000-0110110---

---00100-0-0---0-0 -00--00-01 1100111001

?-?1??110-11001-0000 00011-0-00 000000---0

0000001001 000?????

???????\{1/2\}?? -?10001011 00???11000 00100?01??

0100---0-- -...--0-- - -0000-010 000?-0000-

010--00100-10000000-0001-?000-01?0100---

----00100-0-0---0-0 -00--00-01 2000111101

?-?0??110-1110p-0000 0001100-00 000000---?

????00???1 000?????

????????? -?10001011 00?0?11000 00100?0110

0100---0-- - - - - - - -0000-010 000?-0000-

0?0--00100-10000000-0001-?000-0110100---

----00100 -0-0---0-0 -00--00-01 2000111101

?-?0??110- 11100-0000 0002100-00 000000---?

0000000 ?? 1 000??????

$000100 ? 113-? 0000101100 ? 0 ? 1110100100 ? 01 ? ?$ $0000--0------0---00011010000 ?-1010-$ 100--00110-1001?000-01-1-?1-0-01010?10-----00100 -0-0---0-0 -00--00-00 0021000001 ?-?0??100-3---?-0000 01100-0-00 000040---1 ????10?200 000??????

???????\{1/2\}?? -?00?01011 00?0?11101 00100?01??

$0000-00 \ldots \ldots-0.000-0011010000 ?-1010-$

100--00110-10010000-01-1-?1-0-01010?10--

- --00100-0-0---0-0 -00--00-00 00210-0-01 
Table 1 - Continued.

$01010000211 ? ? 00 ? ? ? 0 ? ?-? 0 ? ? 100-3---?-0000$ 01100-0-00 000040---? 0000011-01 200000-000 000010?200 000?????

Pauropodinae 00 ???0?0?2 0???????? 1 $-01000002-0---2--? 10$ $-00--0 ? 00000001 ? 1100$ 0101000000 0??00???0? 000 ??02-- 200000-100

Polyxenidae

0 ????000?2 0???????? 1 -0101000?? 0---2--?11 -00--0??00 00001?1100 0101000100 0??00???0? 0000001-00 3--0----10

Sphaerotheriidae 00???000?2 0???????? 1 $-01010000-0---2-011$ $-00--0 ? ? 00$ 000???1100 0101000020 0???0???0? 000??01-00 ???0----10

\section{Proteroiulus}

0???00?0?2 0???????? 1

-0101000 ?? 0---2--?11

-10--0??00 000???1100 0101000020 0???0???0? 000??01-01 3--0---10

\section{Narceus}

0???00?012 0????????1

-0101000 ?? $0---2--? 11$ 0101000020 0???0???0? 000??01-01 ???0----10

Spirostreptoidea 0 ????0?0?2 0000000001 -0101000?? 0---2--?11 $-10--0 ? ? 00000 ? ? ? 1100$ 0101000020 0???0???0? 000??01-01 3--0----10

\section{Protura}

0????101?2 0???????? 1

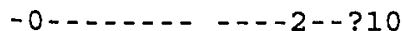
0-00-00000 00????1100 $01010000320 ? ? 00 ? 001 ?$ 000??01-0? ?1?000-010

\section{Arthropleona}

0 ?110101?2 0111000001

$-01000002-0---2--110$

0-00-00000 001?1?1100

0101000042 0??00?001?

$0000000000200100--10$

\section{Campodeidae}

0????000?2 0???????? 1

$-01000000-0---2--? 10$

0-00-00?00 00-?1?1100

01010000211 ??00?111? 0000000?00 ?0?1020000
000100?113-?001?1011 00?0?11101 00100?00-? 00?0---0-- - -----0-- -00011010 000?-1010000--00100-100110?0-01-1-?1-0- 13-0---.-----00?00 -0-0---0-0 -00--00-00 00610-0-01 ?-?1??110-0---?-0000 00000-0-00 100040---1 000000 ?200 000?????

???????\{1/2\}?3 -?00101011 00?1?11101 00100?01?? 0002--0010-0???-00-- - -00011010 000?-?010110--00100-10011000-01-1-?000-13-0--------00100-0-0---0-0 -00--10-00 00?1?00001 ?-?1??110-2---0-0000 00000-0-00 100040---1 0--0000200 000??????

$0001 ? 0 ? 113-? 0010111100 ? ? ? 1110100100 ? 01 ? ?$ 0002--0000 --???-?0-- - -0000-110 000?-?010110--00100-1001?000-01-1-?1-0-23-0---------00100-0-0---0-0 -00--10-00 0001?00001 ?-?0??110-2---?-0000 00000-0-00 000040---1 $0--000 ? 300$ 000??????

???????\{1/2\}?? -?00101111 00???11100 00100001?? 0002--0000--???-?0-- - -0000-010 000?-?010110--00100-10011000-01-1-?1-0- 23-0-.------00?00 -0-0---0-0 -00--10-00 0001?00011 ?-?0??110-2---?-0000 00000-0-01 100040---? $0--000$ ?3?0 001??????

??01???\{1/2\}?? - ?00101111 00??111100 00100001??

0002--0000--???-?0-- - -0000-010 000?-?010-

110--00100-10011000-01-1-?1-0- 23-0--------00?00 -0-0---0-0 -00--10-00 0001?00011 ?-?0??110-2---?-0000 00000-0-01 100040---? $0--100$ ?3? 0 001????00

???????\{1/2\}?? -?00?01111 00???11100 00100001?? $0002--0000--? ? ?-? 0----0000-010000 ?-? 010-$ 110--00100-10011000-01-1-?1-0-23-0-------00?00 -0-0--0-0 -00--10-00 0001?00011 ?-?0??110-2---?-0000 00000-0-01 100040---? $0--? 00 ? 3$ ? 001 ????00

?????????? -?00?01011 00???11001 00210?01?0 0000--0-- - - - --0-- - 0000-010 100?111000000-0-100-2000?1000 0011-?0010 01?10?010? ----00000 -0-0---0-0 -10--00-00 0032100001 ?-?0??110-0---?30000 00000-0-00 001000---? $0-? 000$ ?100 000??????

$000110 ? 203-? 1000101100 ? ? ? 11101000-0001 ? 1$ $000300001110 ? ? ? 00100--? ? 00-? 10$ 100?111000000-0-100-1000?1000 0011-?0010 01010?01?0 ----00100 -0-0---0-0 -10--00-00 0012100001 ?-?0??110-0---?00000 00000-0-00 000000---2 0-0000?000 000??????

$010110 ? 203-? 1000101110 ? ? ? 1110000210 ? 01 ? 1$ 0000---0-- - - ?.0-- -0000-010 110?011000010-0-100-0---?0000 0011-?0011 01010?00?1 -..01100 -0-0---0-0 -10--00-00 0032100001 ?-?0??1000 1002?10100 00000-0-00 000090---? 00?000?100 000?????? 
Table 1 - Continued.

Japygidae

0????100?2 0???????? 1

$-01000000-0---2--? 10$

0-00-00?00 00??1?1100

0101000021 1??00?111?

000??00?00 ?0?102000?

Meinertellidae

0 ????1?0?2 0???????? 1

$-0100011100---2--? 10$

0-00-00?00 000?1?1110

01010000111 ??10?001?

0100?????? ?????????

\section{Machilidae}

0????1?0?2 0???????? 1

$-0100011100---2--? 10$

0-00-00?00 000?1?1110

0101000011 1??10?001?

0100000?10 2111021000

\section{Tricholepidion}

0 ????1?0?2 0??????? 1

-0100011 ?? $0---2--? 10$

1-00-00?00 000?1?1100

0101000011 1??10?001?

0101000??0 2111021000

Lepismatidae

$01110110 ? 20111000001$

$-0100011100---2--110$

1-00-00?00 000?1?1101

0101000010 1?? 10 ? 001?

0101000?10 2111021000

Callibaetis

0 ????1?0?2 0???????? 1

$-01000111-0---2--? 10$

0-00-00?00 000???1101

01010000101 ?? $10 ? 001$ ?

010-?0??00 2001?20000

\section{Periplaneta}

0 ???011012 0111011111

$-0100011110---2--? 10$

0-00-00?00 000???1101

$01010000101 ? ? 10 ? 001$ ?

010--0??10 ?101121000

Locusta

01110110120111011111

$-0100011110---2--110$

0-00-00?00 000???1101

0101000010 0??10?001?

010--00010? 101121000

\section{Drosophila \\ 01110110120111011111 \\ $-0100011110---2--10-$ \\ 0-00-00?00 000???1100 \\ 0101000010 0??10?001? \\ 010--01-?0 ?10102?000}

Hutchinsoniella

0 ???00?011 0???0000? 1
???????\{1/2\}?? -?10?01011 10???11100 000-0?01?1

0000---0------?0-- --0000-010 110?01100-

0010-0-100-0---?0000 0011-?0011 01?10?00?1

----0?100 -0-0---0-0 -10--00-00 0032100001

?-?0??1000 1000?10100 00000-0-00 000090---?

$000001 ? 100$ 000??????

???????\{1/2\}?? -?10001011 10???11100 00200?01??

0003100011 1??????200 - -??00-110 000?01100-

0000-0-101 01110?0000 0021-?0110 01?100001?

-----21100 -0-0---0-0 -10--00-10 0002200001

?-?1??1010 1001?21100 00000-1000 000101---?

????01?100 000??????

$001110 ? 204-? 10001011$ 10?1?11?00 00200001?1 $00031000111000000200--0000-110000 ? 01100-$ 0000-0-101 01110?0000 0021-?0110 0101000010 ----21100 -0-0---0-0 -10--00-10 0002200001 ?-?1??1010 1001?21100.00000-1000 002101---? 000001 ?100 000?????

?????????? -??0?01011 10???11?00 00200?01?? 0013000011 10???10200--0000-110 000?00000000100-101 01120?0001 0021-?0010 01?100000? ----??100 -0-0---0-0 -10--00-10 0002100001 ?-?1??1010 1100?21100 00000-1?00 002101---? $000101 ? 100$ 000?????

$012110 ? 204-110001011$ 10?1?11100 00200001?1 $001300001110 ? ? 010200-0000-110000 ? 00000-$ 000100-101 01120?0111 0021-?0010 0101000000 ?????21100 -0-0---0-0 -10--00-10 0042100001 ?-?1??1010 1100?21100 00000-1100 002101---2 $000101 ? 1000001111 ?$ ?

012????2?? -?10001011 10?1?11000 00200001?0 0013000011 10???20200 - -0000-110 000?01000000100-101 11120?0111 0021-?0010 010100000? ?????21100-0-0---0-0 -110-00-10 0003300001 ?-?1??1010 1100?21100 00000-0-00 00?101---? 002001 ?100 000??????

??2????2?? -?10011011 1011?11000 00200001?0 $000300001110 ? ? ? 20300--0000-110000 ? 00000-$ 000110-101 11120?0111 0021-?0010 010100000? ?????21100-0-0-- $-10-0-111-00-100003300001$ ?-?1??1011 1100?20100 00000-1100 003101---? 000001?100 000??????

$012 ? 10 ? 204-? 10011011101111100000200001 ? 0$ $001300001110 ? ? 020200--0000-110000 ? 00000-$ 000110-101 11120?0111 0021-?0010 0101000000 ?????21100 -0-0---0-0 -111-00-10 0003300001 ?-?1??1011 1100?20100 00000-1100 003101---2 $000001 ? 100$ 000????10

$0120 ? 0 ? 20 ?-1100110111011 ? 11000 \quad 00200001 ? 0$ $001300001110 ? ? 020200--0000-110000 ? 00000-$ _...-1 11120?-1-1 0021-?0010 0101000000 ---01100 -0-0---0-0 -111-00-10 0053300001 ?-?1??1010 1100?20000 00000-0-00 003101---2 $000001 ? 100000111111$

???????0?? -?0?0?1011 00???12100 000-0?01?? $00 ? 0-\cdots 0-1----0---0000-211$ 001?-?-00- 
Table 1 - Continued.

$-0100000 ? ? 0---100 ? 10: 000--0-200-0---0 ? ?-0 ?-100000-00 ? 00 ? 0---$

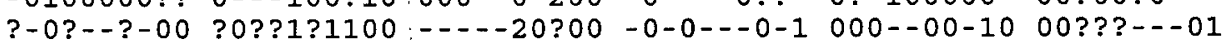

0111110000 0???????? ?-??????- 0----0010 00000-0-00 00??10---?

000 ? 00000 3--0---10?--000?100 000?????

Remipedia

0????0?0? 1

0100000? 0 ? ?????? 1

?-0?--7-00 ?0??10? 100

?-0?--?-00 ?0??1?1100

$000 ? ? 00000$ 3-0000-000

Anostraca

0????00011 0????????1

-1100000 ?? 0---1-1010

?-0?--?-00 ?0??1? 1100

0111111000 0????????

000 ??02-- $20-0---10$

Triops

011??0?011 0????????1

-1100000 ? ? $0--1-1$ ? 10

?-0?--?-00 ?0??1?1100

0111111000 0????????

000??02-- 20-0----10

Limnadia

0????0?0? 1 0???????? 1

-1100000 ?? 0--101? 10

?-0?--?-00 ?0??1?1100

0111111000 0?????????

000 ??02-.-

Daphnia

01???0?0?1 0???????? 1

-1100000 ?

?-0?--?-00 ?0??1?1100

0111111000 0????????

000??02-- 20-0---10

Calanoida

0 ????0?011 0???????? 1

-0100000?? 0---100?10

?-0?--?-00 ?0??1?1100

0111100000 0?????????

000??0??? 3--0---10

Balanidae

0????0?011 0???????? 1

-0-1..-

?-0?--?-00 ?0????1100

$0111 ? 00000$ 0?????????

000??0??00 ?00000-000

Nebalia

0????0?0?1 0???????? 1

$-01100000-0---1--? 10$

?-0?--?-00 ?0??1?1101

0111110000 0????????

000??02-- 20-0----10

Stomatopoda

0 ?? ? 00012

-0110000?? 1-- ???? 1

?-0?--?-00 ?0??1?1101
?????????? -?????10?1 00???12100 000-0?01?? $00 ? 0---0--0----0----? ? 00-211001 ?-?-00-$ $000--0-\{1 / 2\} 00-0---0 ? ?-0 ?-110000-01 ? 00 ? 0---$ - - - 10?00 -0-0---0-0 000--00-10 00???---01 ?-???????- 0----0010 00000-0-00 00??A3---? ?00000???0 000????10

0000?000?1 -1010?1011 00?0?12100 000-1101?? $00 ? 3010011000 ? 000201000000-211001 ?-?-00-$ 000--0-200-0---00?-0?-10-1-0-02000?0------20100 -0-0---0-1 000--00-10 00???---01 ?-???????- 0----0010 00000-0-00 00??60---0 $0--000 ? 000$ 000???111

???????0?? -?010?1011 00?0?12100 000-1101?? 00?3001011 000?00?101 000100-211 0?1?-?-00000--0-200-0----00?-0?-10-1-0-02?00?0---1--20100 -0-0---0-1 000--00-10 00???---01 ?-???????-0----0010 00000-0-00 00??70---? $0--000$ ? 100 000?????

???????0?? -?010?1011 00?0?12100 000-1101?? 00?3001011 02??00?101 000100-211 0?1?-?-00000--0-200-0----00?-0?-10-1-0-02000?0------20100-0-0---0-0 000--00-10 00???---01 ?-???????- 0-1--0010 00000-0-00 00??70---? $0--000 ? 100$ 000?????

0000?000?? -?01001011 00?0?12100 000-1101?? $00 ? 300101102 ? ? 00 ? 101000000-2110 ? 1 ?-?-00-$ 000--0-200-0---00?-0?-10-1-0-02000?0---- - 20100 -0-0---0-1 000--00-10 00???---01 ?-???????- 0----0010 00000-0-00 00???0---0 $0--000 ? ? 00$ 000????11

0000??00?1 -?01011011 001??12?00 000-1101?? $00 ? 0--0-2-1--201010000-211$ 001?-?-00000--0-000-0---0??-0?-110000-01000?0---- -00?00 -0-0---0-1 000--00-10 00???---01 ?-???????- 0----0010 00000-0-00 00??20---? $0--000 ? 100$ 000?????

0000?000?1 -?01001011 0????12100 000-0100-? 00 ?0--0?- 000--0-200-0---0??-0?-1--1-0-01000?0--- - 20100 -0-0---0-1 000--00--0 00???-- 01 ?-???????-0-1--0000 00000-0-00 00??22---0 000000 ??00 000??????

0100?110?1 - ?010?1011 00?1?12100 000-1?01?0 $10 ? 301001100000100---0000-2110 ? 1 ?-?-00-$ 000--0-000-0----00?-0?-101000-01000?0--0100000?00 -0-0---0-1 100-000-10 00???---01

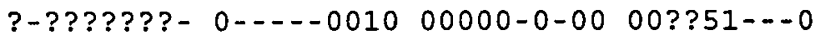
$0--000$ ? 00 000?????

0100?110?1 -?01001?11 00?1?12100 000-1001?? $10 ? 30100110000020201$ 101000-211 0?1?-?-00000--0-000 -0----00?-0?-101000-01000?0--$1011120100-0-0--0-1$ 100-100-10 00???---01 
Table 1 - Continued.

\begin{tabular}{|c|c|c|c|c|c|}
\hline $\begin{array}{l}0111100000 \\
000 ? ? 00000\end{array}$ & $\begin{array}{l}0 \text { ? ?? ? ? ? ? ? } \\
4 ?-0--10\end{array}$ & $\begin{array}{l}\text { ?-?????? ? }- \\
0--000 ? ? 00\end{array}$ & $\begin{array}{l}0-1--0001 \\
000 ? ? ? ? ? ?\end{array}$ & $0-00$ & \\
\hline $\begin{array}{l}\text { Anaspides } \\
0 ? ? ? 00 ? 0 ? 2 \\
-01100000- \\
?-0 ?--?-00 \\
0111110000 \\
000 ? ? 00100\end{array}$ & $\begin{array}{l}01 ? ? 0000-1 \\
1--11-? 10 \\
\text { ?0??1?1101 } \\
0 ? ? ? ? ? ? ? ? ? \\
\text { ??-0----10 }\end{array}$ & $\begin{array}{l}0000 ? 11001 \\
00 ? 3010011 \\
000--0-000 \\
1110020 ? 00 \\
?-? ? ? ? 0 ? ?- \\
0--000 ? ? ? 0\end{array}$ & $\begin{array}{l}-? 010 ? 1011 \\
0111120401 \\
-0---00 ?- \\
-0-0---0-1 \\
0----0001 \\
000 ? ? ? ? ? ?\end{array}$ & $\begin{array}{l}00 ? 1 ? 12100 \\
101000-211 \\
0 ?-101000- \\
100-100-10 \\
00000-0-00\end{array}$ & $\begin{array}{l}000-1 ? 01 ? 0 \\
001 ?-?-00- \\
01000 ? 0-- \\
000 ? ?---01 \\
00 ? ? 51---0\end{array}$ \\
\hline $\begin{array}{l}\text { Oniscidea } \\
0110000012 \\
-01000000- \\
?-0 ?--?-00 \\
0111100000 \\
000 ? ? 00100\end{array}$ & $\begin{array}{l}01110001-1 \\
0--1--010 \\
? 0 ? ? 1 ? 1101 \\
0 ? ? ? ? ? ? ? ? ? \\
40-0----10\end{array}$ & $\begin{array}{l}0100 ? 100 ? ? \\
00 ? 3000011 \\
000--0-100 \\
1011120000 \\
?-? ? ? ? ? ? ?- \\
0--000 ? 100\end{array}$ & $\begin{array}{l}-100001011 \\
01110200- \\
-0---0 ? ?- \\
-0-0--00-1 \\
0----0001 \\
0001011 ? ?\end{array}$ & $\begin{array}{l}00 ? 1112100 \\
--0000-211 \\
0 ?-10 ? 1-0- \\
100-100-10 \\
00000-0-00\end{array}$ & $\begin{array}{l}000-0001 ? 0 \\
001 ?-?-00- \\
02000 ? 0--- \\
00 ? ? ?---01 \\
00 ? ? 51---0\end{array}$ \\
\hline $\begin{array}{l}\text { Reptantia } \\
011 ? 00 ? 012 \\
-01100000- \\
?-0 ?--?-00 \\
0111100000 \\
000 ? ? 00000\end{array}$ & $\begin{array}{l}01110000-1 \\
1---11-010 \\
? 0 ? ? 1 ? 1101 \\
0 ? ? ? ? ? ? ? ? ? \\
40-0----10\end{array}$ & $\begin{array}{l}0000 ? 11001 \\
00 ? 3010011 \\
000--0-000 \\
1111120100 \\
?-? ? ? ? 0 ? ?- \\
0--000 ? ? 00\end{array}$ & $\begin{array}{l}-101001111 \\
0000120 ? 01 \\
-0----0 ? ?- \\
-0-0---0-1 \\
0----0001 \\
000 ? ? ? 111\end{array}$ & $\begin{array}{l}00 ? 1112000 \\
101000-211 \\
0 ?-101000- \\
100-100-? 0 \\
00000-0-00\end{array}$ & $\begin{array}{l}000-1001 ? 0 \\
0 ? 1 ?-?-00- \\
01000 ? 0--- \\
00 ? ? ?---01 \\
00 ? ? 51---0\end{array}$ \\
\hline
\end{tabular}

\section{Appendix 2. Characters optimised on cladogram in Fig. 2}

Characters are numbered as in Appendix 1 and Table 1. Character state changes are optimised as delayed transformations. Changes shown as double-lined arrows are unambiguous, single-lined arrows are ambiguous. Nodes 5, 13, 28 and 48 are not in all shortest cladograms. Nodes 13 and 28 lack apomorphic character support.

Node 1 (Onychophora): $26(0 \longrightarrow 1), 31(0==1), 37(0==>1), 45(0 \longrightarrow>1), 64(0=>4), 103(0 \longrightarrow 3), 115(0 \longrightarrow>4), 172$ $(0==>1), 188(0==>1), 221(0=>1), 251(0==>6), 296(0==>1), 311(0=>1)$

Node 2 (Tactopoda): $25(0 \longrightarrow 1), 49(0 \longrightarrow 1), 177(0==1), 178(0=>1), 222(0==>1)$

Node 3 (Euarthropoda): $17(0==>1), 19(0->1), 20(0==>1), 50(0==>1), 60(0==>1), 103(0 \longrightarrow 2)$

Node 4 (Pantopoda): $13(1 \longrightarrow 0), 78(0==>1), 85(0==>1), 115(0 \longrightarrow 3), 141(0==>1), 186(0 \longrightarrow 1), 189(0 \longrightarrow>1), 193$ $(0 \rightarrow 1), 275(0=>8)$

Node 5: $191(0 \rightarrow 1)$

Node 6: $23(0 \longrightarrow 1), 26(0 \longrightarrow 1), 27(0 \longrightarrow 1), 53(0 \longrightarrow 1), 89(0=>1), 99(1==>0), 220(0==>1), 224(0==1)$

Node 7 (Chelicerata: Euchelicerata): $2(0 \rightarrow 1), 10(0 \rightarrow 2), 51(0=>1), 55(0 \longrightarrow 1), 78(0=>3), 186(0 \rightarrow>1), 189$ $(0 \longrightarrow>1), 190(0=\Rightarrow 1), 194(0==>1), 207(0==>1), 275(0==>3), 291(2==>1)$

Node 8 (Xiphosura): $4(0 \rightarrow>1), 64(0 \longrightarrow>3), 68(0==>1), 76(0 \rightarrow>1), 88(0==>2), 175(0 \longrightarrow>1), 192(0=>1), 198$ $(0==>1), 209(0==>1), 223(0==>1), 244(1==>0), 261(0==>1), 306(0==>2)$

Node 9 (Arachnida): $41(0==>1), 79(0==>1), 115(0 \longrightarrow 3), 196(0 \longrightarrow>1), 197(0==>1), 228(0==>1), 246(0=\Rightarrow 1)$

Node 10 (Tetrapulmonata): $11(0==1), 29(0=\Rightarrow 1), 32(0 \longrightarrow>1), 47(0 \longrightarrow>1), 64(0 \longrightarrow>1), 77(0==1), 86(0 \rightarrow>1)$, $94(0=>1), 112(0==>1), 113(0=>1), 195(0->2), 199(0==1), 208(0==1), 224(1==>0), 232(0=\Rightarrow 1), 233$ $(0==1), 245(0 \longrightarrow 1), 277(0==>1), 278(0=\Rightarrow 1), 300(0=>1), 301(0=\Rightarrow 1), 302(0==>1), 303(0 \rightarrow 1)$ 
Node 11 (Dromopoda): $100(0=\Rightarrow 1), 101(0==>1), 114(0 \longrightarrow>1), 191(0 \longrightarrow 1), 241(0=\Rightarrow 1), 242(0=>1), 243$ $(0=\Rightarrow 1)$

Node 12 (Opiliones): $85(0=\Rightarrow 1), 194(1==>0), 236(0==>1), 240(0 \longrightarrow 2), 251(0=>5), 269(0==>1), 272(0==>1)$, $279(0 \longrightarrow 2), 287(0==>2), 299(0=\Rightarrow 1), 312(0==>1)$

Node 14 (Mandibulata): $103(2==>1), 115(0=>2), 119(0==>1), 128(0==>1), 144(0==>1), 152(0==>1), 175$ $(0 \longrightarrow 1), 188(0=>1), 309(1=>0), 317(0 \longrightarrow 1)$

Node 15 (Myriapoda): $13(1 \longrightarrow 0), 30(0=\Rightarrow 1), 33(0=>1), 50(1 \longrightarrow 2), 98(0=>1), 121(0 \longrightarrow 1), 132(0 \longrightarrow 1), 247$ $(0 \rightarrow 1)$

Node 16 (Chilopoda): $8(0 \longrightarrow 2), 28(1==>2), 47(0=\Rightarrow 1), 64(0==>2), 96(1==>0), 122(0=\Rightarrow 1), 126(0=\Rightarrow 1), 137$ $(0==1), 153(0=\Rightarrow 1), 170(0==1), 212(0=>1), 229(0 \longrightarrow 2), 235(0==>1), 286(0 \longrightarrow 1), 292(0=>1), 298(0-$ $>1), 300(0==1)$

Node 17 (Pleurostigmophora): $59(0 \rightarrow>1), 62(0==>1), 135(0 \rightarrow 1), 155(0==1), 164(0==1), 171(0=\Rightarrow 1), 251$ $(0 \longrightarrow 1), 283(0==>1), 287(0 \longrightarrow 1), 310(0==>1)$

Node 18 (Epimorpha s.1.): $28(2=\Rightarrow 0), 39(0=>1), 164(1=>2), 165(0=\Rightarrow 1), 166(0=\Rightarrow 1), 168(0=\Rightarrow 1), 173$ $(0==>1), 174(0==>1), 176(0==>1), 211(0==>1), 217(0==>1), 244(1==0), 264(0=\Rightarrow 1), 281(0==>1)$

Node 19 (Epimorpha s.str.): $13(0==>1), 30(1==>), 163(0==>1), 210(0=\Rightarrow 1), 216(0=>1), 252(0=\Rightarrow 1), 265$ $(0==1)$

Node 20 (Scolopendromorpha): $127(0==>1), 156(0==>1), 167(0==>1), 255(0==>1), 285(0==>1), 307(0==>1)$

Node 21 (Geophilomorpha): $64(2 \longrightarrow 0), 98(1==0), 106(0=\Rightarrow 1), 121(1==0), 126(1=>0), 135(1=\Rightarrow 0), 137$ $(1=\Rightarrow 0), 211(1 \longrightarrow 2), 212(1=>0), 218(0=>1), 253(0==>1), 266(1 \longrightarrow 0)$

Node 22 (Progoneata): $4(0 \longrightarrow 1), 8(0 \longrightarrow 1), 9(0==>1), 10(0 \longrightarrow 3), 86(0==>1), 87(0 \longrightarrow 1), 135(0 \longrightarrow 1), 142$ $(0=\Rightarrow 1), 147(0==>1), 214(0 \longrightarrow 1), 215(1==>0), 275(0==>4), 280(0==>1), 287(0 \longrightarrow>1), 308(0==>2)$

Node 23 (Symphyla): $120(0 \rightarrow 1), 129(0==>1), 154(0==>1), 157(0 \longrightarrow>1), 213(0==>2), 229(0 \longrightarrow>2), 230(0==>1)$, $231(0==>1), 244(1==>0), 248(1==>0), 251(0==>3), 262(0==>1), 263(0==>1), 305(0==>1)$

Node 24 (Dignatha): $15(0=>1), 136(0==>1), 151(0==>1), 152(1==>3), 271(0==1)$

Node 25 (Diplopoda): $64(0==>2), 105(0==>1), 120(0 \longrightarrow>1), 122(0=\Rightarrow 1), 206(0=>1), 251(0==>2), 291(2==>3)$, $299(0==1)$

Node 26 (Chilognatha): $18(0==>1), 86(1==>0), 151(1==>2), 229(0 \longrightarrow>2), 244(1==>0), 308(2==3)$

Node 27 (Heminthomorpha: Eugnatha: Juliformia): $30(1=>0), 162(0=\Rightarrow 1), 219(0==>1), 270(0=\Rightarrow 1), 290(0==>1)$, $313(0==>1)$

Node 29 (Tetraconata): $12(0==>1), 42(0==>1), 43(0 \longrightarrow 1), 52(0=\Rightarrow 1), 54(0 \longrightarrow 1), 69(0 \longrightarrow>1), 700==>1), 308$ $(0=>1), 314(0 \Rightarrow>1), 316(0 \Rightarrow>1), 318(0=\Rightarrow 1)$

Node 30 (Hexapoda): $4(0 \longrightarrow 1), 5(0 \longrightarrow 1), 8(0 \longrightarrow 2), 10(0 \longrightarrow 3), 44(0 \longrightarrow 1), 46(0=\Rightarrow 1), 50(1 \longrightarrow 2), 71(0 \longrightarrow 1)$, $97(0 \longrightarrow 1), 118(0==1), 143(0 \longrightarrow 1), 149(0=>1), 154(0==>1), 202(0==1), 214(0 \longrightarrow 2), 239(0 \longrightarrow 1), 247(0-$ $>1), 280(0==2)$

Node 31 (Ellipura): $30(0=\Rightarrow 1), 48(0==>1), 91(0 \longrightarrow 1), 95(0 \longrightarrow 1), 137(0==>1), 158(0==>1), 230(0 \longrightarrow 2), 244$ $(1 \longrightarrow 0), 299(0=>1)$

Node 32 (Insecta): $21(0==>1), 40(0 \longrightarrow>1), 187(0==1), 230(0 \longrightarrow>1), 231(0==>1), 248(1=>0), 251(0=>1), 258$ $(0==>1), 294(0 \longrightarrow 1), 296(0==>2)$ 
Node 33 (Diplura): $91(0 \longrightarrow 1), 92(0=>1), 123(0=\Rightarrow 1), 150(0 \Rightarrow>1), 160(0=>1), 213(0 \longrightarrow 3), 229(0 \longrightarrow>2), 237$ $(0==>1), 238(0==>1), 244(1 \longrightarrow 0), 256(0 \rightarrow 1), 275(0==>9)$

Node 34 (Ectognatha): $3(0=\Rightarrow 1), 10(3=>4), 24(0 \longrightarrow>1), 33(0 \longrightarrow 2), 64(0=>3), 78(0=\Rightarrow 2), 88(0=>1), 107$ $(0==>1), 108(0=>1), 109(0==>1), 130(0==>1), 132(0 \longrightarrow>1), 133(0 \longrightarrow>1), 134(0 \longrightarrow>1), 143(1==>2), 186(0==2)$, $209(0==>1), 229(0 \longrightarrow>1), 234(0==>1), 249(0==>1), 256(0 \longrightarrow>2), 257(0==>1), 267(0==>1), 274(0==>1), 276$ $(0==>1), 282(0==>1), 289(0=>1), 292(0=>1), 293(0 \rightarrow 1), 297(0 \rightarrow 1), 306(0 \rightarrow 1)$

Node 35 (Archaeognatha): $65(0=\Rightarrow 1), 148(0==>1), 159(0==>1), 179(0==>1), 215(1==>2), 254(0==>1)$

Node 36 (Dicondylia): $63(0=>1), 76(0=\Rightarrow 1), 96(1=>0), 97(1=>0), 124(0==>1), 134(1==>2), 140(0==>1)$, $252(0==>1), 273(0 \longrightarrow 2), 284(0==>1)$

Node $37: 1(0 \longrightarrow 1), 3(1 \longrightarrow 2), 47(0 \longrightarrow>1), 138(0==>1), 139(0==>1), 180(0==>1), 230(1==>0), 268(0 \rightarrow>1), 315$ $(0 \longrightarrow>1)$

Node 38 (Pterygota): $28(1==>0), 40(1==>0), 76(1==>2), 131(0=\Rightarrow 1), 203(0==>1), 214(2==>3), 215(1=\Rightarrow 3)$, $293(1=>0)$

Node 39 (Metapterygota: Neoptera): $16(0=>1), 56(0 \longrightarrow 1), 57(0 \longrightarrow>1), 58(0 \longrightarrow 1), 59(0 \longrightarrow 1), 110(0 \longrightarrow 1), 204$ $(0 \longrightarrow 1), 257(1==>0), 273(2 \longrightarrow 3)$

Node 40 (Orthopteroidea): $125(0 \longrightarrow 1), 250(0=>1), 295(0==>1)$

Node 41 (Crustacea): $27(1==>2), 88(0==>2), 90(0==>1), 93(0==1), 115(2==>1), 209(0==>1), 223(0==>1)$, $225(0==>1), 259(0==>1), 291(2=\Rightarrow 3)$

Node 42 (Eucrustacea): $10(0 \longrightarrow 1), 13(1 \longrightarrow 0), 14(0 \longrightarrow 1), 80(0 \longrightarrow 1), 128(1 \longrightarrow 2), 200(0=>1)$

Node 43 (Maxillopoda): $36(0 \longrightarrow 1), 78(0==2), 82(0 \longrightarrow 1), 275(0 \longrightarrow 2)$

Node 44 (Thoracopoda): $145(1==0), 186(0 \rightarrow 2), 226(0=>1), 299(0 \rightarrow 1)$

Node 45 (Phyllopodomorpha): $35(0=>1), 64(0=>3), 291(3=>2), 319(0 \longrightarrow 1)$

Node 46 (Branchiopoda): $36(0 \longrightarrow 1), 102(0=>1), 117(0 \longrightarrow>1), 147(0=>1), 152(1=\Rightarrow 2), 227(0==>1), 287(0-$ $>2$ )

Node 47 (Phyllopoda): $67(0==1), 78(0 \longrightarrow 1), 275(0 \longrightarrow 7)$

Node 48 (Diplostraca): $72(0==>2)$

Node 49 (Malacostraca): $6(0==>1), 7(0==>1), 24(0 \longrightarrow>1), 66(0 \longrightarrow>1), 76(0==>1), 104(0==>1), 128(2==>0), 146$ $(0 \longrightarrow 1), 180(0=>1), 201(0=>1), 275(0 \longrightarrow 5), 276(0=>1)$

Node 50 (Eumalacostraca): $50(1=>2), 76(1=\Rightarrow 2), 81(0 \longrightarrow>1), 83(0=\Rightarrow 1), 111(0=\Rightarrow 1), 181(0 \longrightarrow 1), 183(0-$ $>1), 184(0 \longrightarrow 1), 185(0 \longrightarrow 1), 205(0 \longrightarrow 1), 226(1==0), 259(1=>0), 260(0==>1), 291(2==>4)$

Node 51 (Caridoida): $116(0==>1)$

Node 52 (Xenommacarida): $72(0=\Rightarrow 1), 73(0=\Rightarrow 1), 74(0==>1), 288(0==>1)$ 